UNIVERSIDADE DE SÃO PAULO

PROGRAMA DE PÓS-GRADUAÇÃO INTERUNIDADES

EM ESTÉTICA E HISTÓRIA DA ARTE

MARIA CÁSSIA CAETANO

A importância da imaterialidade em Maliévitch

e um olhar pós-suprematista em Rothko

São Paulo 
MARIA CÁSSIA CAETANO

\section{A importância da imaterialidade em Maliévitch e um olhar pós-suprematista em Rothko}

\section{Versão Original}

Dissertação apresentada ao Programa de Pós-Graduação Interunidades em Estética e História da Arte da Universidade de São Paulo para obtenção do título de Mestre em Arte.

Linha de Pesquisa: Metodologia e Epistemologia da Arte

Orientadora: Profa. Dra. Carmen S. G. Aranha

São Paulo

2019 
Autorizo a reprodução e divulgação total ou parcial deste trabalho, por qualquer meio convencional ou eletrônico, para fins de estudo e pesquisa, desde que citada a fonte.

\section{Catalogação da Publicação}

Biblioteca Lourival Gomes Machado

Museu de Arte Contemporânea da Universidade de São Paulo

Caetano, Maria Cássia.

A importância da imaterialidade em Maliévitch e um olhar pós-suprematista em Rothko / Maria Cássia Caetano ; orientadora Carmen S. G. Aranha. -- São Paulo, 2019.

114 f. : il.

Dissertação (Mestrado - Programa de Pós-Graduação Interunidades em Estética e História da Arte) -- Universidade de São Paulo, 2019.

1. Suprematismo. 2. Abstracionismo. 3. Arte Moderna - Rússia - Século 20. 4. Maliévitch, Kazimir, 1879-1935. 5. Rothko, Mark, 1903-1970. I. Aranha, Carmen S. G. II. Título.

CDD 759.065 
Nome: CAETANO, Maria Cássia

Título: A importância da imaterialidade em Maliévitch e um olhar pós-suprematista em Rothko

Dissertação apresentada ao Programa de Pós-Graduação Interunidades em Estética e História da Arte da Universidade de São Paulo para obtenção do título de Mestre em Arte.

Aprovado em:

Banca Examinadora

Profa. Dra.

Instituição:

Julgamento:

Profa. Dra.

Instituição:

Julgamento:

Profa. Dra.

Instituição:

Julgamento:

Profa. Dra.

Instituição:

Julgamento: 
Desejo que este trabalho seja uma forma de homenagear a todos os artistas, "reconhecidos ou não": dos que pisam em terra firme aos que alçam voos, mesmo sem um rumo definido.

Dedico este trabalho a meu querido e insubstituível pai (in memoriam), por sempre me fazer sentir tão especial, e à minha querida mãe, por sempre segurar minhas mãos. 


\section{AGRADECIMENTOS}

Agradeço a Deus pela vida.

Agradeço a meus pais por tudo que fizeram e fazem por mim.

Agradeço a meu irmão por me mostrar o que um lápis é capaz de fazer, desenhista nato.

Agradeço a minha irmã por todo o carinho e entendimento de sempre.

Agradeço a todos os amigos e familiares que entenderam minhas ausências. Um abraço especial para: Andréia dos Reis, Ariadne Caetano, Lilian Brito, Rosimeire Aller e Simone Tartuce pelo apoio e incentivo de sempre.

Agradeço ao empresário da Tchayka Turismo, Gustavo Leal, por aceitar uma permuta com trabalhos de design gráfico em troca de uma viagem à Rússia.

Agradeço ao Centro Cultural Banco do Brasil por ceder um dos últimos exemplares do livro sobre a exposição: Gráfica Utópica - Arte gráfica Russa - 1904-1942. A exposição no CCBB foi realizada nos anos de 2001 e 2002.

Agradeço à orientadora Profa. Dra. Carmen Aranha pela oportunidade, competência, humildade, interesse, disposição e carinho depositados neste trabalho e em minha pessoa. Sou eternamente agradecida por me proporcionar a realização de um sonho.

Agradeço a Profa. Dra. Elza Ajzenberg por aceitar estar na banca e pelo interesse por este projeto, com comentários e sugestões no exame de qualificação que foram imprescindíveis para o amadurecimento desta pesquisa.

Agradeço a Prof. Dra. Alecsandra de Oliveira por aceitar estar na banca e por pontuar questões que deveriam ser revisitadas, no exame de qualificação, para o melhor desenvolvimento deste trabalho.

Agradeço a Prof. Dra. Renata Rocco por aceitar estar na banca; tenho certeza de que trará profundas contribuições.

Agradeço a todo o corpo docente do Programa de Pós-Graduação Interunidades em Estética e História da Arte, ECA e FFLCH.

Agradeço a todos os funcionários do Programa de Pós-Graduação Interunidades em Estética e História da Arte pela boa vontade emauxiliar-nos.

Agradeço a Universidade de São Paulo. 
"E aqueles que foram vistos dançando foram julgados insanos por aqueles que não podiam escutar a música".

Friedrich Nietzsche 


\section{RESUMO}

CAETANO, Maria Cássia. A importância da imaterialidade em Maliévitch e um olhar póssuprematista em Rothko. 2019. 114 f. Dissertação (Mestrado em Estética e História da Arte) Programa de Pós-Graduação Interunidades, Universidade de São Paulo, 2019.

Este é um estudo sobre a importância da imaterialidade encontrada na obra de Kazímir Sievierínovitch Maliévitch (1878-1935), artista, pintor, filósofo, professor e arquiteto russo, considerado um dos principais precursores da arte abstrata. Os ideais de um mundo melhor e sem objetos, defendidos pelo artista, tiveram como consequência uma proposta visual representada por uma simplicidade nas formas e cores, com imensa sofisticação filosófica e intelectual. Num período de guerras e revoluções, os artistas dessa geração buscavam novas propostas. Não havia mais espaço para uma arte puramente contemplativa. Para a compreensão de suas obras, dependemos de uma extensa pesquisa pictórico-filosófica, com temas relacionados ao visível e ao sensível, para assim criarmos um possível juízo de valor. Faremos também um breve estudo sobre a imaterialidade contida na obra de Mark Rothko (1903, Rússia - 1970, Nova Iorque), baseado em um olhar pós-suprematista. Para o estudo e abordagem dessas características da visualidade, nos apropriaremos de alguns aspectos do pensamento de Merleau-Ponty, para então justificarmos um possível olhar pós-suprematista em Rothko.

Palavras-chave: Maliévitch. Suprematismo. Rothko. Arte Moderna. Espiritual. 


\begin{abstract}
CAETANO, Maria Cássia. The importance of immateriality in Maliévitch and the postsuprematist look at Rothko. 2019. 114 f. Dissertation (Mestrado em Estética e História da Arte) - Programa de Pós-Graduação Interunidades, Universidade de São Paulo, 2019.

This is a study on the importance of immateriality found in the work of Kazimir Sievierinovich Maliévitch (1878 - 1935), artist, painter, philosopher, teacher and Russian architect, considered one of the main precursors of abstract art. The ideals of a better world and without objects, defended by the artist, had as consequence a visual proposal represented by a simplicity in the forms and colors, with immense philosophical and intellectual sophistication. In a period of wars and revolutions, the artists of this generation were seeking new proposals, there was no more space for a purely contemplative art. For the understanding of his works we depend on an extensive pictorial-philosophical research, with themes related to the visible and the sensitive, in order to create a possible value judgment. We will also make a brief study of the immateriality contained in the work of Mark Rothko (1903 - Russia, 1970 - New York), through a postsuprematist look. For the study and approach of these characteristics of visuality we will appropriate some aspects of Merleau-Ponty's thought, to justify a possible post-suprematist look in Rothko.
\end{abstract}

Keywords: Maliévitch. Suprematism. Rothko. Modern Art. Spiritual. 


\section{LISTA DE FIGURAS}

Figura 1 - N. Goncharova: Corte do feno -1910 ....................................................... 22

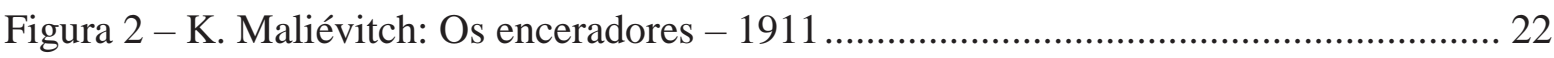

Figura 3 - M. Larionov: Raísmo azul - 1912 _................................................................ 23

Figura 4 - O que você Almeja meu Amigo! - 1868 ...................................................... 24

Figura 5 - Cartaz de Maliévitch com texto de Maiakovski.................................................. 24

Figura 6 - K. Maliévitch: Pedicuro no Banheiro - 1908-1909 …....................................... 25

Figura 7 - P. Cézanne: Os Jogadores de Cartas - 1890-1892 ............................................ 25

Figura 8 - C. Monet: The Portal and the Tour d'Albane (Morning Effect) - 1892 ............. 27

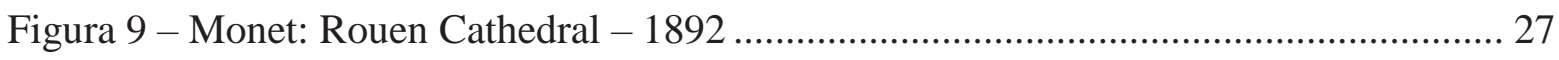

Figura 10 - K. Maliévitch: Paisagem com Casa Amarela - 1906-1907 ............................. 28

Figura 11 - K. Maliévitch: Garota das flores - 1904-1905 _.............................................. 29

Figura 12 - K. Maliévitch: Estudo para um afresco (autorretrato) - 1907 .......................... 30

Figura 13 - K. Maliévitch: Estudo para pintura de afresco - 1907 .................................... 31

Figura 14 - K. Maliévitch: Repouso. Sociedade de Cartola - 1908 ................................... 32

Figura 15 - H. Matisse: A Sala Vermelha - 1908-1909 .................................................. 32

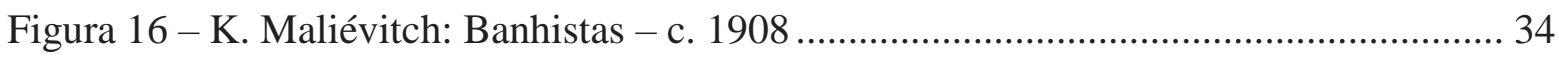

Figura 17 - P. Cézanne: Grandes Banhistas - 1900-1906 ................................................. 34

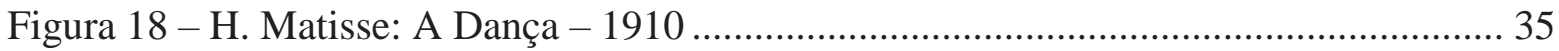

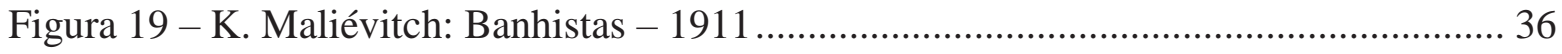

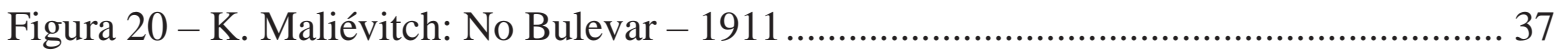

Figura 21 - K. Maliévitch: Camponesa com baldes e criança - 1912 ................................ 38

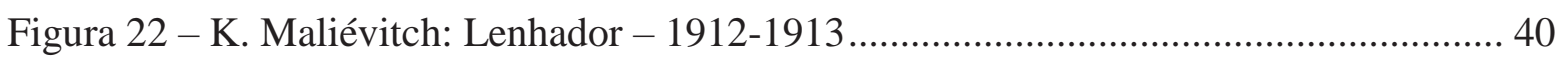

Figura 23 - K. Maliévitch: Ceifeiro sobre fundo vermelho - 19 ..................................... 41

Figura 24 - F. Léger: A mulher de azul - 1912 ............................................................... 42

Figura 25 - K. Maliévitch: Amolador. Princípio de Animação - 1913 ................................. 43

Figura 26 - M. Duchamp: Nu descendant un escalier $n^{\circ} 2$ - 1912-1916 ............................. 43

Figura 27 - K. Maliévitch: Retrato Aperfeiçoado de Ivan Kliun - 1913 ........................... 44

Figura 28 - K. Maliévitch: Vaca e violino - 1913 ............................................................ 45

Figura 29 - K. Maliévitch: Um inglês em Moscou - 1914 ................................................ 46

Figura 30 - Mãe de Deus do Enternecimento de Vladimir ............................................... 50

Figura 31 - Mãe de Deus Odiguítria de Jerusalém ................................................................ 51

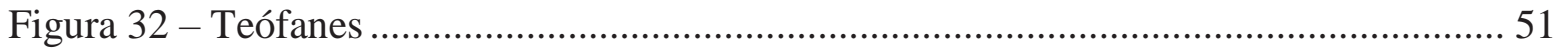




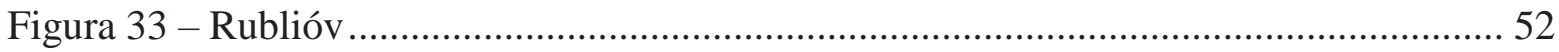

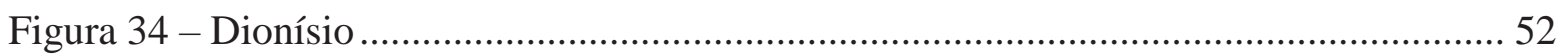

Figura 35 - K. Maliévitch: Representação da Vitória sobre o Sol - 1913 ........................... 56

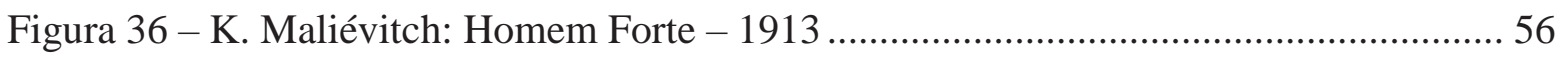

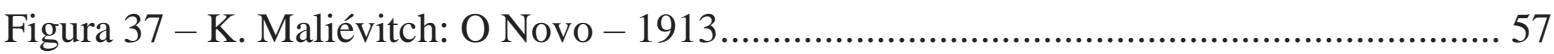

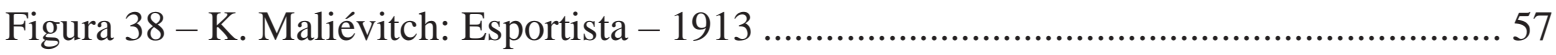

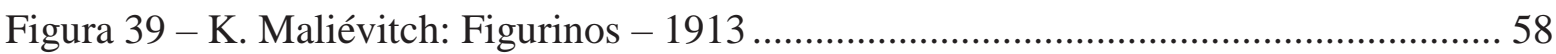

Figura 40 - K. Maliévitch: Quadrado negro - 1913 (estudo cenográfico da ópera Vitória

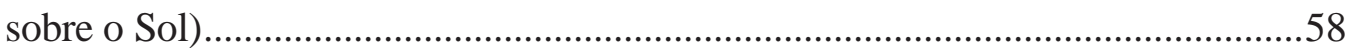

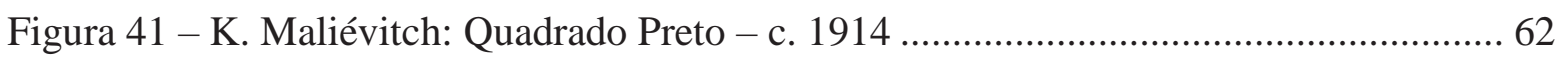

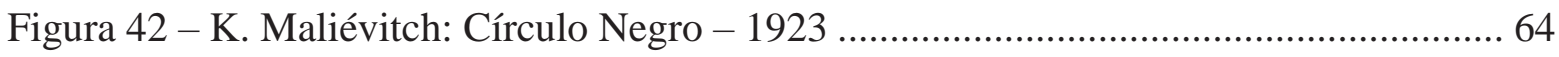

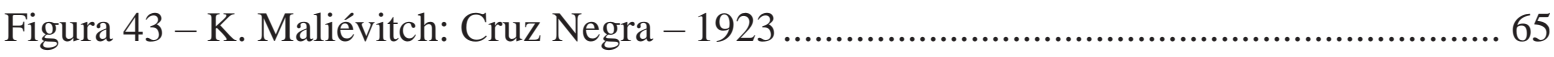

Figura 44 - K. Maliévitch: Quadrado Vermelho - Realismo Pictórico da Camponesa em Duas Dimensões - 1915 ........................................................ 67

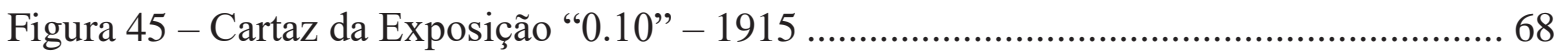

Figura 46 - Foto da exposição "0.10. A última exposição futurista" - 1915 ........................ 69

Figura 47 - K. Maliévitch: Composição Suprematista:

Voo de Aeroplano - 1915 (datado de 1914) ................................................. 70

Figura 48 - K. Maliévitch: Autorretrato em duas dimensões - 1915 ................................ 71

Figura 49 - K. Maliévitch: Suprematismo - 1916-1917 _..................................................... 71

Figura 50 - K. Maliévitch: Suprematismo - 1916-1917 _................................................ 72

Figura 51 - K. Maliévitch: Pintura suprematista - 1917-1918 _.......................................... 72

Figura 52 - K. Maliévitch: Quadrado branco sobre fundo branco - 1918 .......................... 74

Figura 53 - K. Maliévitch: Pintura Suprematista - 1917-1918_....................................... 75

Figura 54 - Exposição Do Impressionismo ao Suprematismo............................................. 76

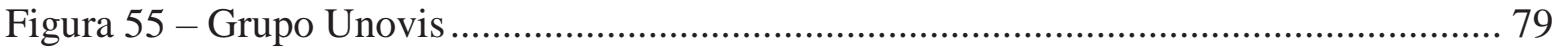

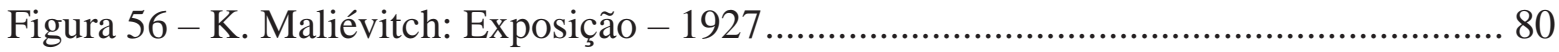

Figura 57 - K. Maliévitch: Figura de braços estendidos em cruz - 1933 ............................ 81

Figura 58 - K. Maliévitch: Suprematismo. Figura Feminina - 1928-1932 _......................... 81

Figura 59 - K. Maliévitch: Torso feminino - 1928-1932 ….......................................... 82

Figura 60 - K. Maliévitch: Camponeses no campo - 1929 ............................................... 83

Figura 61 - K. Maliévitch: Esportistas - 1930-1932 .................................................. 83

Figura 62 - K. Maliévitch: Para a colheita II - 1928-1929 ............................................. 85

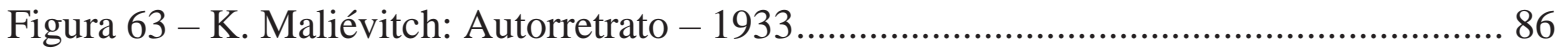


Figura 64 - Albrecht Dürer: Autorretrato com casaco de Pele - 1500 ............................... 86

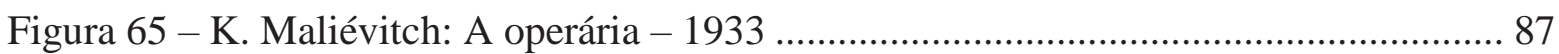

Figura 66 - K. Maliévitch: Garota com Bastão Vermelho - 1932 ..................................... 87

Figura 67 - K. Maliévitch: Cabeça de camponês - c. 1928-1929....................................... 88

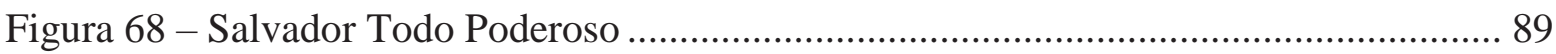

Figura 69 - K. Maliévitch: A Cavalaria Vermelha - 1928-1932 _....................................... 89

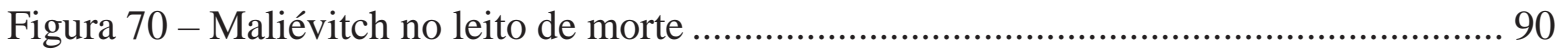

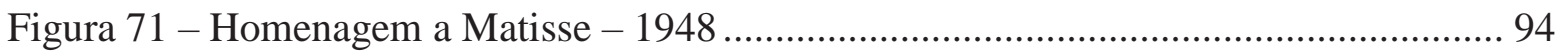

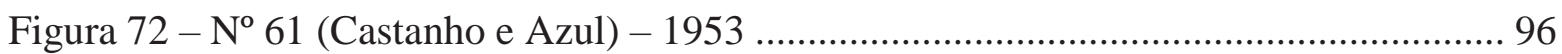

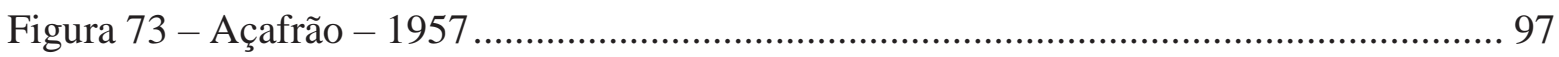

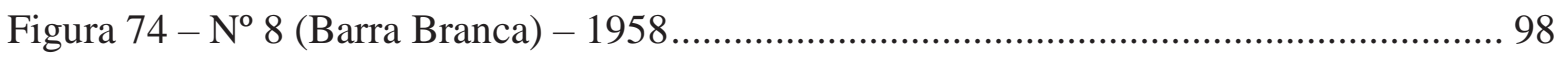

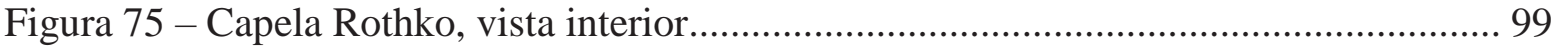

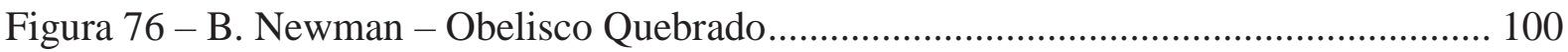




\section{SUMÁRIO}

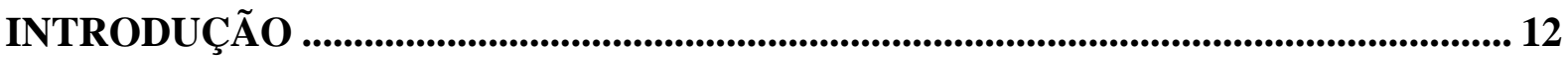

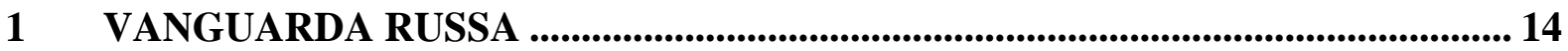

1.1 Século XIX e o ideal de uma nova cultura russa ................................................... 15

1.2 A vanguarda e a Primeira Guerra Mundial .............................................................. 19

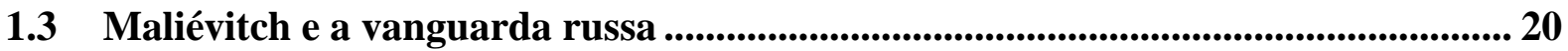

2 TRAJETÓRIA ARTÍSTICA DE MALIÉVITCH ................................................ 26

2.1 O visível e o invisível em Maliévitch .................................................................46

2.2 O Suprematismo........................................................................................................... 54

2.3 A figuração no Suprematismo.............................................................................................. 78

3 UM OLHAR PÓS-SUPREMATISTA:

ASPECTOS DA OBRA DE MARK ROTHKO.......................................................... 91

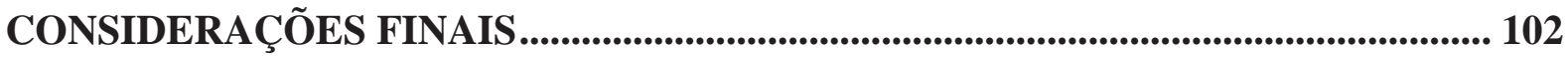

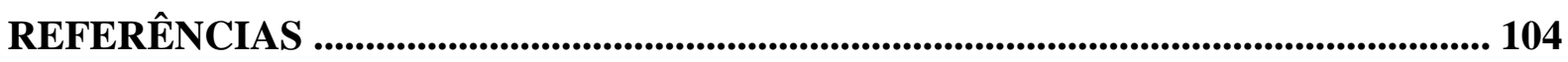

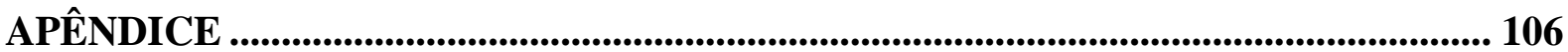




\section{INTRODUÇÃO}

Desde criança, meu "universo particular" sempre foi permeado por canetinhas e lápis de cor. Ao menos dois sábados por mês meu pai e eu íamos à lojinha da Dona Maria para comprar uma caixinha nova. Esse interesse pelo desenho e pela cor desenvolveu-se um pouco mais durante o período que estudei num colégio técnico em desenho de comunicação. Nesse colégio, obtive embasamento teórico e técnico sobre pintura e também tive o primeiro contato com grandes mestres da pintura. Depois da universidade, num curso de tecnologia, comecei a atuar em agências de comunicação como designer gráfica e a desenvolver, em paralelo, um trabalho de pintura no MUBE, acompanhado pelo Prof. Marco Giannotti e depois pelo Prof. Paulo Pasta no Instituto Tomie Ohtake. Frequentando essas aulas, comecei a ter percepções diversificadas sobre a arte e a pintura. Nessa época, o estilo de minhas pinturas oscilava entre figurativo e abstrato, então passei por muitas influências artísticas, algumas conscientes e outras inconscientes, consigo perceber hoje.

Nos trabalhos de design gráfico, que costumam atender a um cliente comercial, sempre me baseio em questões artísticas, enquanto nas pinturas sempre houve um leve pensamento racional, mais próximo do universo do design. Se por um lado são propostas artísticas diferentes, por outro há um discurso visual interno em mim que de algum modo sempre os uniu. Depois da especialização em Linguagens Visuais, comecei a pensar e a desenvolver trabalhos de criação sem a necessidade de rotulá-los. Com relação à pintura, a paleta cromática talvez seja a característica que mais tenha sofrido alterações. Depois de passar por alguns processos e pela grande admiração cromática dos expressionistas alemães, notei que minhas telas tendiam à monocromia e ao branco, que ora era chapado, ora com diferentes graus de transparência. As veladuras dessas pinturas tinham o intuito de esconder parte da obra, por pertencer a um mundo que não mostra-se por completo. Nesse momento, além do desejo de migrar profissionalmente para a carreira acadêmica, a pintura pela pintura começava a perder força, e percebi a necessidade de algum "tipo de pensamento" e embasamento. Foi nesse período que iniciei, como aluna especial, no Programa de Pós-Graduação Interunidades em Estética e História da Arte, período que vivenciei ótimas experiências com o Prof. Edson Leite e com a Profa. Elza Ajzenberg, que, ao ouvir meus questionamentos sobre o branco e a invisibilidade, aconselhou-me a pesquisar sobre Maliévitch. O mais interessante é que minhas pinturas desse momento eram quase como uma releitura das obras de Maliévitch, e a Profa. Elza nunca as tinha visto. O amor à Rússia já era antigo. Em 2002, visitei a exposição 500 anos de Arte Russa, na Oca, no Parque Ibirapuera, e em 2006 visitei o país. 
Ingressei no mestrado com o privilégio de ter a Profa. Carmen Aranha como orientadora. Depois de conversarmos sobre as questões do branco e da importância do visível e do invisível, orientou-me para alcançar o objeto de estudo desta pesquisa, além de ter realizado a orientação durante todo o processo do trabalho.

Adotando a pesquisa exploratória, pude obter o levantamento bibliográfico necessário para o desenvolvimento do trabalho, e, com o intuito de apresentar uma pesquisa descritiva, realizei inúmeras buscas sobre os respectivos artistas e suas obras, em livros e cursos. Houve também a preocupação de levantar fatores históricos determinantes para o desenvolvimento deste projeto.

Na considerada "primeira fase da abstração", alguns artistas, entre eles Maliévitch, demonstraram por meio de suas obras a importância do que não se vê, mas nem por isto deixou de existir. O fato que mais me chamou a atenção sobre a obra de Maliévitch foi a simplicidade pictórica de suas pinturas, em especial da fase suprematista, que instiga o observador a buscar um maior conhecimento, além da proposta visual. É justamente o estudo sobre a importância da imaterialidade que encontraremos nesta dissertação. O estudo sobre o velado e o exposto é igualmente importante para esta pesquisa.

[...] olhar a expressão criadora é ver, em uma atmosfera de movimentações e tensões, a razão construtiva, a razão conceitual, a expressividade perceptiva, a expressividade simbólica. São aproximações possíveis que podem ser vistas não apenas nas obras, mas, sobretudo, entre elas e, desse modo, situam os horizontes de significados visuais pertencentes à linguagem artística (ARANHA; BRITO; ROSATO, 2011, p. 57).

Numa visita técnica ao MoMa - Museum of Modern Art (Nova Iorque), ao me deparar com o Quadrado Branco, senti a força imposta pela pintura e a sensação de impotência diante da tela. O Quadrado estaria cobrindo uma fresta, um “divisor de mundos". Atrás do quadro haveria de existir um outro mundo, perfeito em todos os sentidos, e somente algumas pessoas poderiam acessá-lo. Nessa mesma visita, ao me deparar com uma pintura de Rothko, tive a sensação de pertencer à tela. Senti-me pequena diante daquele extenso "campo de cor"; senti uma sinergia física e espiritual estabelecida por meio de corpos físicos e olhares da alma. Com essa experiência, notei a força da imaterialidade também em Rothko. Por este motivo, no terceiro capítulo desta dissertação, apresentamos um breve pensamento sobre o metafísico em Rothko, com o intuito de contemporanizar um aspecto tão importante da obra de Maliévitch, a imaterialidade. Para isso, utilizamos uma percepção pós-suprematista sobre sua obra, com leves pinceladas de Merleau-Ponty, um filósofo que navegou levemente entre o visível e o sensível. 


\section{VANGUARDA RUSSA}

A Rússia começou a participar da vida cultural europeia somente a partir do Iluminismo, ainda assim, foi considerada economicamente atrasada até o início do século XX, pois, além de desenvolver uma agricultura primitiva, apresentava um grande índice de analfabetismo. Moscou era a plataforma do comércio russo no século XVI, fato que teve como consequência a intensificação da expansão da cidade. O reinado de Pedro ${ }^{1}$, o Grande, entre os séculos XVII e XVIII, foi o período de maior transformação da Rússia, uma vez que pôs fim à dominação da Igreja sobre a cultura, embora tenha conseguido pouco impacto social. A servidão prosseguiu e fortaleceu a elite local; o poder e a riqueza permaneciam nas mãos da nobreza. Pedro mudou a estrutura e a forma do Estado, estabeleceu uma nova capital, São Petersburgo, e converteu o Império Russo tradicional numa variante da Monarquia Europeia. Devido ao foco comercial ter migrado para São Petersburgo, os aristocratas e nobres mudaram-se para o novo centro econômico. Os nobres começaram a construir palácios seguindo o estilo europeu, com paredes decoradas com retratos, paisagens, naturezas mortas e pinturas baseadas em temas históricos, mitológicos e bíblicos. Pedro considerava os hábitos tradicionais russos como bárbaros e rudes, por isso a necessidade de europeizar os hábitos russos. Ele defendia que, para um país ser considerado culto e polido, seria necessário viver num estado organizado de acordo com os padrões europeus. Todas essas mudanças realizadas no reinado de Pedro, que durou 36 anos, levaram séculos para serem estabelecidas na Europa Ocidental.

O pensamento e a estética, de acordo com os padrões europeus, permaneceram até a revolução de 1917, data de término do regime czarista.

Depois da morte de Pedro, alguns líderes continuaram no governo russo por um curto período. Catarina, a Grande, mulher de Pedro III, assumiu o poder, posto adquirido por meio de um golpe ${ }^{2}$. A imperatriz governou a Rússia entre 1762 e 1796, e tinha presença marcante na vida cultural europeia. Correspondia-se com Voltaire, Denis Diderot e outras mentes iluministas de sua época, sendo influenciada por estes grandes pensadores. Apoiou inúmeros projetos culturais,

\footnotetext{
1 “O reinado de Pedro foi um período de muitas guerras e conquistas. Dentre as principais está a vitória contra os turcos, foi construída uma marinha para dificultar o acesso dos turcos via mar; também delimitou a fronteira com a China; e uma longa guerra com a Suécia, considerada uma potência invencível, seus objetivos eram a conquista territorial, inclusive de um porto que tivesse uma localização que facilitasse o comércio e a comunicação, nesta guerra foram obtidos alguns êxitos, mas também houveram períodos difíceis" (BUSHKOVITCH, 2015).

2 “[...] O assassinato pode não ter sido planejado, pois todos os presentes, incluindo Pedro, estavam embriagados - mas, seja como for, o assassinato ocorreu [...] Com Pedro fora do caminho, a outrora obscura princesa alemã era agora - aos 33 anos de idade - Catarina II, imperatriz da Rússia” (BUSHKOVITCH, 2015).
} 
universidades, academias e criou escolas secundárias em todas as capitais provinciais, além de uma rede de escolas primárias. Com relação às artes visuais, havia o predomínio da Academia de Arte, cujos professores eram, em sua maioria, de origem francesa. Para os artistas plásticos havia um apoio financeiro, desde que os respectivos trabalhos fossem destinados para os palácios da imperatriz, da nobreza e da igreja. Esse fato trouxe como consequência às artes visuais russas uma imensa limitação, pois, além de terem de respeitar as características oficiais da Academia, os artistas tinham que seguir os modelos europeus, com pinturas históricas no estilo classicista, sem personalidade própria.

Ao fazermos uma análise do reinado de Catarina, a Rússia ainda era um país muito pobre, com o predomínio de uma sociedade agrária e servil. Novamente, a evolução cultural foi mais fácil e rápida se comparada às mudanças sociais e políticas, ocasionando uma sociedade mais desenvolvida no setor cultural do que nos setores social e político. Por outro lado, era o maior país da Europa, e a estrutura do Estado havia incentivado o crescimento do comércio, da indústria, da educação e da ciência, apesar dos pensamentos políticos continuarem baseando-se nos europeus. Depois de um longo período em que o país parecia ter alcançado o mínimo de estabilidade, a Revolução Francesa eclode, gerando outros novos desafios.

\subsection{Século XIX e o ideal de uma nova cultura russa}

A partir de 1870, comerciantes milionários, como Savva Mamontov, tomaram o lugar dos czares e dos aristocratas. Segundo Gray (2004, p. 9), "o berço do movimento moderno em arte russa pode ser localizado na colônia de artistas reunidos por Savva Mamontov, o magnata russo das estradas de ferro". Mamontov uniu-se aos artistas progressistas de sua época e juntos constituíram o primeiro desafio à Academia de São Petersburgo, cujo sistema nobre e burocrático controlava a vida artística do país desde Catarina, a Grande. Os artistas desligaram-se da Academia e formaram um grupo denominado, por eles próprios, como os Errantes. O grupo tinha como ideal a criação de uma nova cultura russa, com o intuito de apresentar a arte ao cidadão comum, uma arte útil para a sociedade. Nesse período foi inaugurada a Galeria Estatal Tretyakov com o intuito de preservar e divulgar a arte nacional da Rússia.

Os integrantes não aceitavam o ideal da "arte pela arte" e defendiam que a verdadeira função da arte era explicar a vida e comentá-la. A arte estaria a favor da mudança social, e o seu tema central deveria ser descrever o camponês, o homem comum, como um novo herói. Este modo de pensar era compartilhado por Dostoiévski, Tolstói e Turguêniev. Os Errantes não 
estavam diretamente envolvidos com o movimento "Eslavófilo"3, mas alguns artistas das gerações seguintes afastaram-se do Ocidente em busca de uma cultura nacional embasada no camponês russo e em suas tradições artísticas. O repúdio ao neoclassicismo internacional, que havia dominado o campo artístico russo desde o final do século XVIII, e o redescobrimento da herança artística nacional deram origem a uma escola de pintura moderna na Rússia (GRAY, 2004).

Na década seguinte, em 1880, estudantes do Colégio May, sob a liderança de Alexander Benoir, criaram outro movimento, o Mundo da Arte, que defendia a arte como um instrumento para a salvação e inspiração da humanidade (GRAY, 2004). De acordo com os preceitos desse movimento, o artista teria uma função sacerdotal dedicada ao caminho da beleza eterna. Segundo Gray (2004, p. 28), “A arte era vista como uma forma de experiência mística, um meio através do qual a beleza eterna poderia ser expressa e comunicada". A palavra "arte", nesse caso, deveria ser compreendida num sentido amplo, incluindo literatura e música. Os estudantes do Colégio May eram filhos da intelligentsia abastada de São Petersburgo, e, assim como Benoir, seus pais tinham descendência europeia. Benoir descreve o Mundo da Arte como uma sociedade com o intuito de organizar exposições e criar uma revista que pudesse influenciar e inspirar a sociedade rumo ao universo artístico. Devido ao fato de os integrantes do grupo terem descendência europeia e sofrerem influências da Europa, eles acreditavam ter como missão restabelecer na Rússia a cultura que havia se perdido com os Errantes. Almejavam um país que entrasse no "circuito internacional" e não fosse mais visto como um posto provinciano avançado com uma tradição nacional isolada.

Em apenas uma década, podemos notar os diferentes e opostos focos artísticos entre os Errantes e o Mundo da Arte. Enquanto os Errantes buscavam instaurar uma arte que valorizasse a cultura local russa e o homem comum - características perdidas desde o mandato de Pedro -, o Mundo da Arte teve um foco completamente diferente, o retorno à valorização da cultura Europeia. O grupo ansiava por uma arte que pudesse participar do circuito internacional. Para isso, voltaram a buscar referências artísticas no maior centro artístico: a Europa Ocidental.

Diaghilev ${ }^{4}$, primo de um dos integrantes do Mundo da Arte, teve uma educação menos polida que os demais do grupo e por isso era percebido como uma pessoa de nível cultural menor, porém era comunicativo e enérgico. Em 1895, Diaghilev foi para o exterior e começou a colecionar pinturas (GRAY, 2004).

\footnotetext{
${ }^{3} \mathrm{O}$ movimento Eslavófilo caracterizou-se pela rejeição à cultura ocidental e aos padrões de "imitação" da cultura europeia inseridos por Pedro, o Grande (GRAY, 2004).

${ }^{4}$ Diaghilev foi um importante coreógrafo russo. Devido ao fato de ter se indisposto com autoridades, o seu "Ballet Russo de Diaghilev" nunca se apresentou na Rússia, somente na América e Europa (GRAY, 2004).
} 
De volta à Rússia com obras recém-adquiridas, começou a ser mais considerado pelos membros do grupo e, em dois anos, organizou suas primeiras exposições. Essas exposiçõesforam brilhantes e marcaram o início do Mundo da Arte como uma sociedade de exposições. A primeira revista do grupo foi publicada em 1898. A ideia, nessa fase, era proporcionar uma arte autônoma, sem vínculos com religião, propaganda ou política. Notamos, nesse período, tendências que irão florescer em manifestos artísticos do início do século $\mathrm{XX}$, como a ideia de autonomia da arte e a preocupação com o eterno.

No último ano da revista, 1904, os pintores franceses pós-impressionistas foram acolhidos. O grupo inicialmente tendia mais aos interesses artísticos de Viena, Böcklin e à Escola de Munique. Entre os anos de 1905 e 1910, os movimentos de arte russa estiveram conectados com o desenvolvimento de outros centros europeus. Nesse período, a Rússia se tornou um ponto de encontro para as ideias progressistas. A vanguarda russa desenvolveu um estilo que propiciou, para a década seguinte, a criação de uma escola russa independente. Foram organizadas exposições de enorme importância. Os artistas russos tiveram contato com os trabalhos e movimentos que estavam acontecendo no "berço artístico", a Europa Ocidental. As portas da pintura europeia se abriam para os artistas e para o público russo. O sucesso desse período de livre intercâmbio cultural e do renascimento da cultura russa em geral pode ser atribuído ao Mundo da Arte. O Mundo da Arte também criou a proposta de um público comprador de quadros. Para um cidadão rico ser reconhecido como culto, era essencial que ele fosse um colecionador de pinturas. Com esse novo desejo de colecionar, surgiram famosos colecionadores de arte, entre eles Shchukin e Morosov, que adquiriram inúmeras pinturas francesas pós-impressionistas. Essas obras ficavam nas suas respectivas mansões e poderiam ser visitadas, proporcionando conhecimento e enorme influência aos pintores russos.

Assim, foi como se através das coleções de Morosov e Shchukin, os artistas russos passassem por um curso intensivo sobre pintura francesa revolucionária dos últimos quarenta anos, fazendo com que as mais avançadas ideias e movimentos dos últimos dez anos se tornassem até mesmo mais familiares em Moscou do que na própria Paris [...] (GRAY, 2004, p. 41).

A afinidade espiritual entre os membros do Mundo da Arte e da Escola Simbolista constituiu uma das características principais das escolas Cubo-Futuristas e das futuras pinturas abstratas que iriam se desenvolver na Rússia durante os anos de 1910 a 1921. O auge do trabalho criativo do Mundo da Arte foi no teatro e especialmente no ballet. Seus ideais de uma existência aperfeiçoada e integrada na completa realização da "vida como arte" eram possíveis. Com o passar dos anos, o Mundo da Arte começou a provocar um sentimento de inquietude nos artistas mais jovens, que passaram a protestar contra a erudição dos pintores do grupo, alegando que os 
membros estavam perseguindo o conhecimento e apresentando obras com características herdadas do Movimento Simbolista, como destruição, pessimismo, o mundo num ambiente estranho, morte e decadência. Como consequência dessa insatisfação surge a segunda geração, o grupo "Rosa Azul", com um foco totalmente diferente da primeira geração. Agora os temas estavam relacionados à vida, ao amor materno, ao nascimento, à arte como parte integrante da sociedade. O Rosa Azul rejeitava a ideia renascentista de uma pintura como "algo" que apresentasse o mundo ideal, diferente da realidade cotidiana. Diaghilev também teve um papel importante na formação deste grupo.

A revista Tosão de Ouro, do grupo Rosa Azul, tinha como patrocinadores ricos comerciantes que se interessavam pela propagação da arte russa no país e na Europa. Além de continuar o trabalho do Mundo da Arte, a revista defendia a vanguarda em suas publicações e patrocinava exposições. O Tosão de Ouro ainda organizou três exposições históricas. Na primeira exposição, em 1908, foram apresentados trabalhos de pintores franceses e russos com o intuito de revelar as peculiaridades entre a pintura francesa e a russa.

Em janeiro de 1909, a segunda exposição, denominada franco-russa, foi considerada como uma apresentação da arte francesa para o grande público russo. As pinturas foram apresentadas juntas e no mesmo ambiente, inclusive obras pré-cubistas, como Le Grand $\mathrm{Nu}$ e Natureza Morta, de Braque (GRAY, 2004). Nesse momento, já poderíamos notar que a pintura russa trilhava por outros caminhos. Enquanto os franceses eram mais sensuais, os russos eram mais espirituais. Na terceira exposição, em 1909, os pintores Larionov e Goncharova lançaram o estilo Primitivista. Foram exibidos trabalhos que apresentavam influências fauvistas, bordados da Sibéria, além de brinquedos tradicionais e os $l u b o ́ k^{5}$, xilogravuras camponesas. Notamos, nesse momento, que, apesar da forte influência da vanguarda Europeia, houve paralelamente uma busca pela arte local.

O intercâmbio cultural proporcionado pelas exposições de trabalhos de artistas europeus e russos e o grande número de encomendas feitas pelos colecionadores começaram a despertar nos artistas europeus a vontade de conhecer o país.

Depois que as revistas publicadas por grupos artísticos acabaram, seus colaboradores continuaram a criar suas próprias publicações. Surgiram outras revistas de menor alcance, como Escalas e Novos Rumos (GRAY, 2004). Nessas revistas, manteve-se uma das inovações mais importantes do Mundo da Arte: a unicidade artística. Essa característica foi fundamental para que vários artistas, com diferentes tipos de especializações, pintores, poetas, cenógrafos,

\footnotetext{
${ }^{5}$ [...] lubók arte popular russa, folhetos semelhantes ao nosso folheto de cordel com um grande número de ilustrações (AGUILAR, 2002).
} 
trabalhassem em conjunto na construção de um único trabalho. Essa característica foi muito utilizada e desenvolvida na Rússia durante as décadas de 1910 e 1920.

\subsection{A vanguarda e a Primeira Guerra Mundial}

Moscou e Petrogrado (antes da guerra era São Petersburgo) tornaram-se palco de atividades concentradas entre os artistas desde o início do século XX. As duas cidades tiveram o maior crescimento comercial e econômico de todo o país. Com a eclosão da Guerra em 1914, o país sofreu um retrocesso em seus próprios recursos. Esse período de isolamento forçado se estendeu até o período revolucionário de 1917 e permaneceu até 1921. Houve um fortalecimento do movimento pré-revolucionário suprematista e da escola pós-revolucionária construtivista. Durante esse período, ambos amadureceram de tal modo que, quando a comunicação para fora da Rússia novamente tornou-se possível, no início da década de 1920, esses dois movimentos que cresceram somente dentro da Rússia eram desconhecidos na Europa Ocidental, causando grande impacto com sua descoberta. Berlim tornou-se o centro de ideias vindas de toda a Europa, e a contribuição da arte russa foi fundamental. Os ideais do Suprematismo e do Construtivismo ganharam destaque. Em 1915, uma exposição organizada em Petrogrado chamada "0.10. A última exposição futurista" reuniu novamente Maliévitch e Tatlin ${ }^{6}$; Maliévitch representando o Suprematismo e Tatlin, o Construtivismo. Foi nessa exposição que ambos emergiram como líderes, cada um de uma escola. O grupo de artistas que compartilhava dos ideais de Maliévitch, como Kandinsky, Chagall, Pevsner e Gabo, acreditava que a função do artista deveria ser espiritual e educativa, enquanto o grupo de Tatlin, Rodchenko e Lissitzky acreditava que a ação artística deveria ser uma ação de construção. Assim, a arte industrial seria a nova arte popular. De acordo com Dempsey (2008, p. 106), “embora suas obras compartilhem certas características visuais - ambas são abstratas e geométricas, Maliévitch e Tatlin tinham ideias opostas sobre o papel da arte”. Esse conflito ideológico impediu que a arte abstrata na Rússia fosse um movimento unificado.

A nova Rússia encontrava-se devastada devido ao longo período de guerras e revoluções. Os artistas que compartilhavam dos ideais de Maliévitch apoiavam a revolução bolchevique e estavam ansiosos para serem membros úteis para esta "nova sociedade" que estava surgindo. Apoiavam a reconstrução, afirmando que o crescimento deveria ser obtido por meio da

\footnotetext{
${ }^{6}$ Em 1919, Tatlin projetou o "Monumento à Terceira Internacional”. Uma enorme torre, de ferro, com um centro de informação de alta tecnologia, telas ao ar livre para transmitir notícias e propaganda e um equipamento para projetar imagens nas nuvens. Foi um projeto audacioso que não saiu da prancheta (DEMPSEY, 2008).
} 
industrialização. Maiakóvski defendia uma arte que fosse capaz de contribuir na construção de praças e pontes, pois o país precisava de uma força-tarefa para a reconstrução de indústrias, bondes e fábricas. Não havia mais espaço para uma arte de "museu". Foi um momento de intensos questionamentos políticos, que geravam uma sensação de força para a reconstrução do país. Depois de um ano da Revolução, a Rússia começou a divulgar propagandas com a figura do homem, representado como um gigante, associado ao estereótipo de heroico e trabalhador, com desenhos e pinturas naturalistas. Chegou o momento de uma arte que respondia ao realismosocialista. Com o Proletkult, Organização para a Cultura Proletária, a arte era vista como um produto social em que o proletariado tinha que ter sua própria arte, uma arte de "classe", com o objetivo de organizar suas forças, sempre favorecendo o socialismo. Depois de debates entre artistas e dirigentes sobre a importância do artista na sociedade, foram elaboradas algumas conclusões sobre os prós e contras da arte utilitária. Desde o início havia uma divisão entre os membros do Instituto, ocasionando a criação de dois grupos: o de Maliévitch e o de Tatlin.

\subsection{Maliévitch e a vanguarda russa}

Conforme já vimos, uma das características da vanguarda russa foi a união de artistas de diferentes áreas trabalharem em conjunto para a entrega de uma obra única. Segundo Aguilar (2002, p. 36), “[...] Você conjuga o fazer de Maiakóvski, ao de Eisenstein e por aí vai. Você dá a impressão de que é impossível mexer numa zona de sensibilidade, sem tocar em outra". Maliévitch participou de alguns grupos de artistas e de exposições de grande importância. Um dos principais movimentos foi o Der Blaue Reiter (O Cavaleiro Azul) ${ }^{7}$, fundado por Vassili Kandinsky em 1911. Seus participantes não compartilhavam de um estilo de trabalho em comum, mas partilhavam da ideia de que, como cada artista tinha uma visão pessoal, caberia a ele escolher o modo de representação da respectiva ideia. Maliévitch também participou da segunda exposição do Der Blau Reiter, em 1912, na galeria Goltz, em Munique, em que foram expostos, no total, 315 trabalhos, de 31 artistas. Infelizmente, com a eclosão da Primeira Guerra Mundial, o grupo foi dissolvido.

[...] Der Blaue Reiter é um grupo mais restrito, sem um programa preciso, mas com uma orientação decididamente espiritualista. A finalidade é coordenar e defender, através de exposições internacionais cuidadosamente escolhidas e com textos teóricos e polêmicos, todas as tendências pelas quais (explica Kandinsky) a esfera da arte se distingue nitidamente da esfera da natureza [...] (ARGAN, 1992, p. 318).

\footnotetext{
7 “[...] grupo de artistas residentes em Munique, ativo de 1911 a 1914” (DEMPSEY, 2008).
} 
Outro grupo importante que teve a participação de Maliévitch foi o Osslíni Khvost (Rabo de Burro), em 1921. O ideal desse grupo era a primeira ruptura consciente com a Europa, resultando em uma escola russa independente. A única exposição do grupo foi a primeira a unir os quatro grandes artistas da época: Larionov, Goncharova, Maliévitch e Tatlin. Os artistas que mais influenciaram o trabalho de Maliévitch nessa fase foram Natalia Goncharova e Larionov. Goncharova nasceu em uma família nobre de uma pequena aldeia próxima a Moscou, cresceu em ambiente rural, mudou-se para estudar em Moscou, mas nunca se adaptou por completo à vida urbana. Na faculdade, conheceu Larionov e daí em diante tornaram-se inseparáveis na arte e na vida. Em 1903, expuseram juntos e conheceram Diaghilev, que os convidou a participar de outras exposições. Goncharova foi muito influenciada pela pintura de ícones. Larionov ganhou o título de melhor impressionista russo em seus primeiros trabalhos. A pintura de Goncharova (Figura 1) nos atinge com violência e impacto imediato. Em seus trabalhos primitivistas, fez uma série com temas agrícolas. O próprio Maliévitch admite suas influências nos trabalhos desse período (Figura 2).

Goncharova e eu trabalhamos mais no nível camponês. Todo o nosso trabalho tinha um conteúdo, que, embora expresso de forma primitiva, revelava uma preocupação social. Esta, a diferença básica entre nós e o grupo Valete de Ouros que estava trabalhando na linha Cézanne (GRAY, 2004, p. 77).

O Raionismo ${ }^{8}$ insinua uma mensagem que dissolve a forma numa movimentação vertiginosa de linhas, conforme observamos na pintura Raísmo azul (Figura 3), de Larionov.

\footnotetext{
${ }^{8} \mathrm{O}$ "Raionismo" foi um breve movimento artístico criado por Larionov e Goncharova em Moscou. Defendiam uma arte abstrata em que a pintura mostraria não os objetos, mas a intersecção de raios refletidos por eles (DEMPSEY, 2008).
} 
Figura 1 - N. Goncharova: Corte do feno - 1910

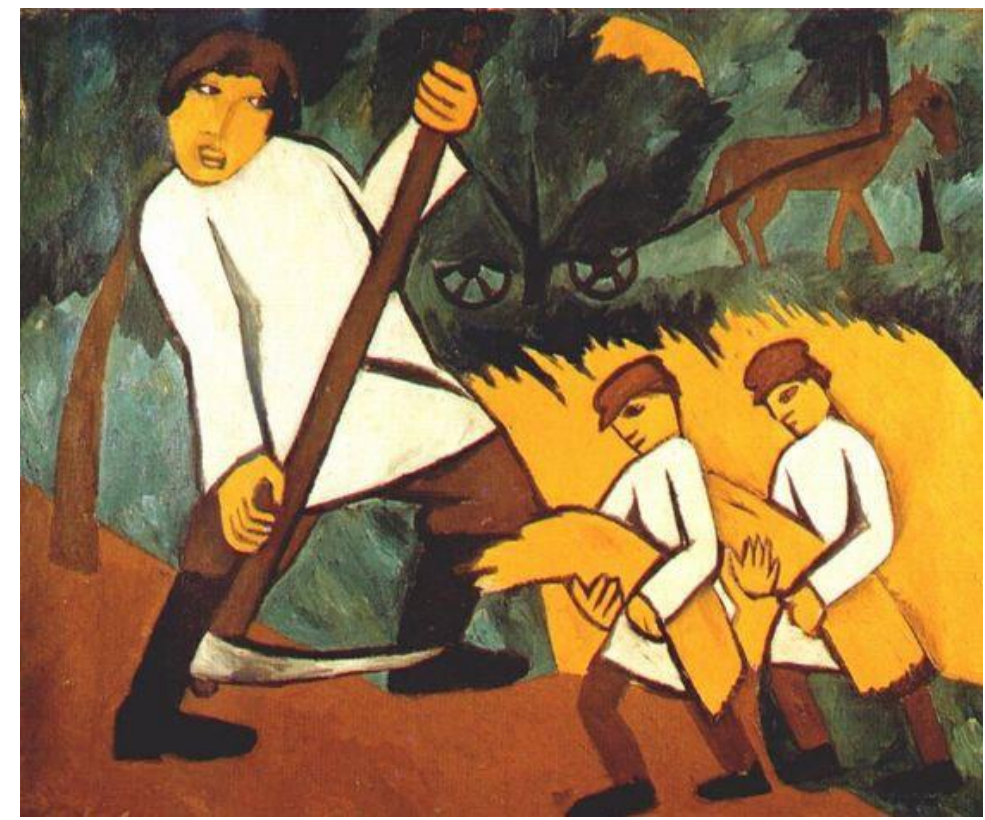

Fonte: Gray (2004). Coleção da artista. Paris.

Figura 2 - K. Maliévitch: Os enceradores - 1911

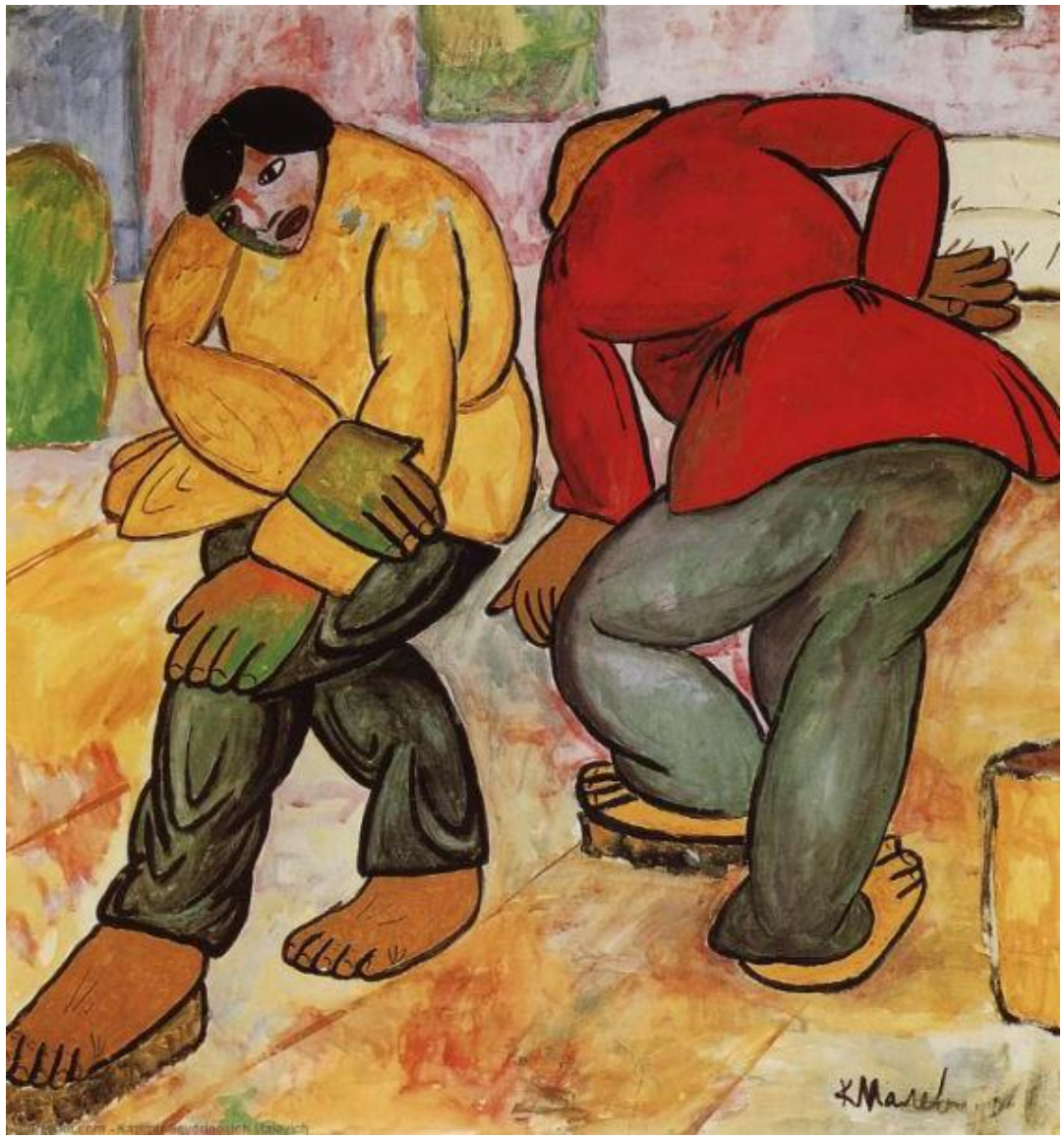

Fonte: Souter. Gouache on cardboard. $77,7 \times 71 \mathrm{~cm}$. Stedelijk Museum, Amsterdã. 
Figura 3 - M. Larionov: Raísmo azul - 1912

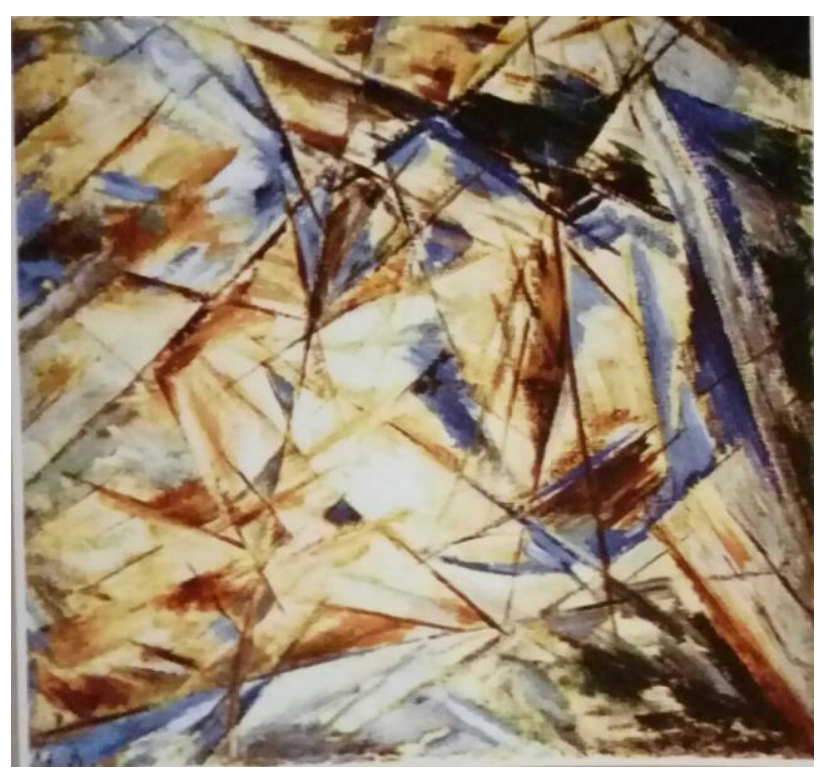

Fonte: Gray (2004).

A exposição Osslíni Khvost foi simultânea à Der Blau Reiter, em Munique. Vários artistas participaram das duas exposições. Outra característica presente nos grupos foi o grande interesse pela arte folclórica e infantil. O Der Blau Reiter incluiu sete xilogravuras sobre os camponeses russos do século XIX. Kandinsky e Maliévitch “emprestaram” do folclore russo suas combinações de cores. Maliévitch fez litografias que imitavam os lubók russos (Figuras 4 e 5). No passado, os lubók retratavam temas religiosos e políticos. Depois passaram a retratar canções e danças para os camponeses. O artista colaborou com 23 trabalhos, entre eles Camponeses e Pedicuro no Banheiro (Figura 6), em que notamos nitidamente influências da pintura de Cézanne Os Jogadores de Cartas (Figura 7) (GRAY, 2004). 
Figura 4 - O que você Almeja meu Amigo! - 1868

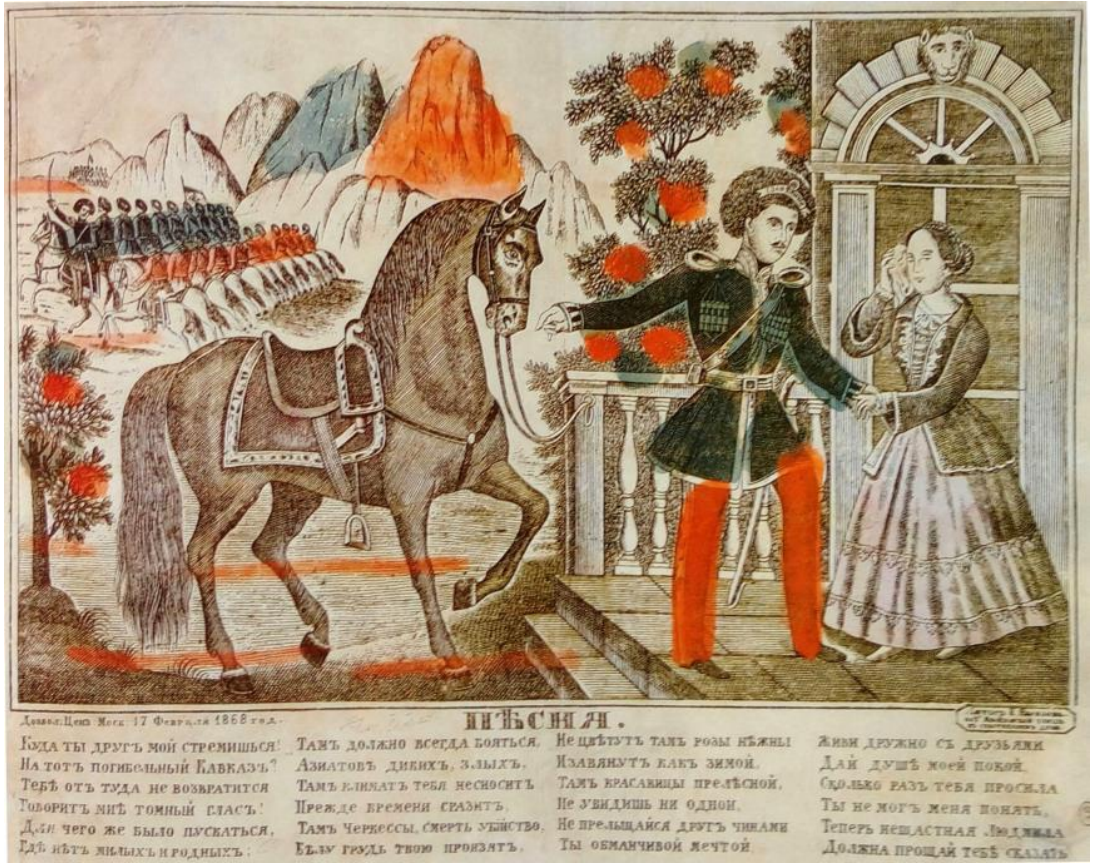

Fonte: Aguilar (2002). Litografia pintada.

Figura 5 - Cartaz de Maliévitch com texto de Maiakóvski

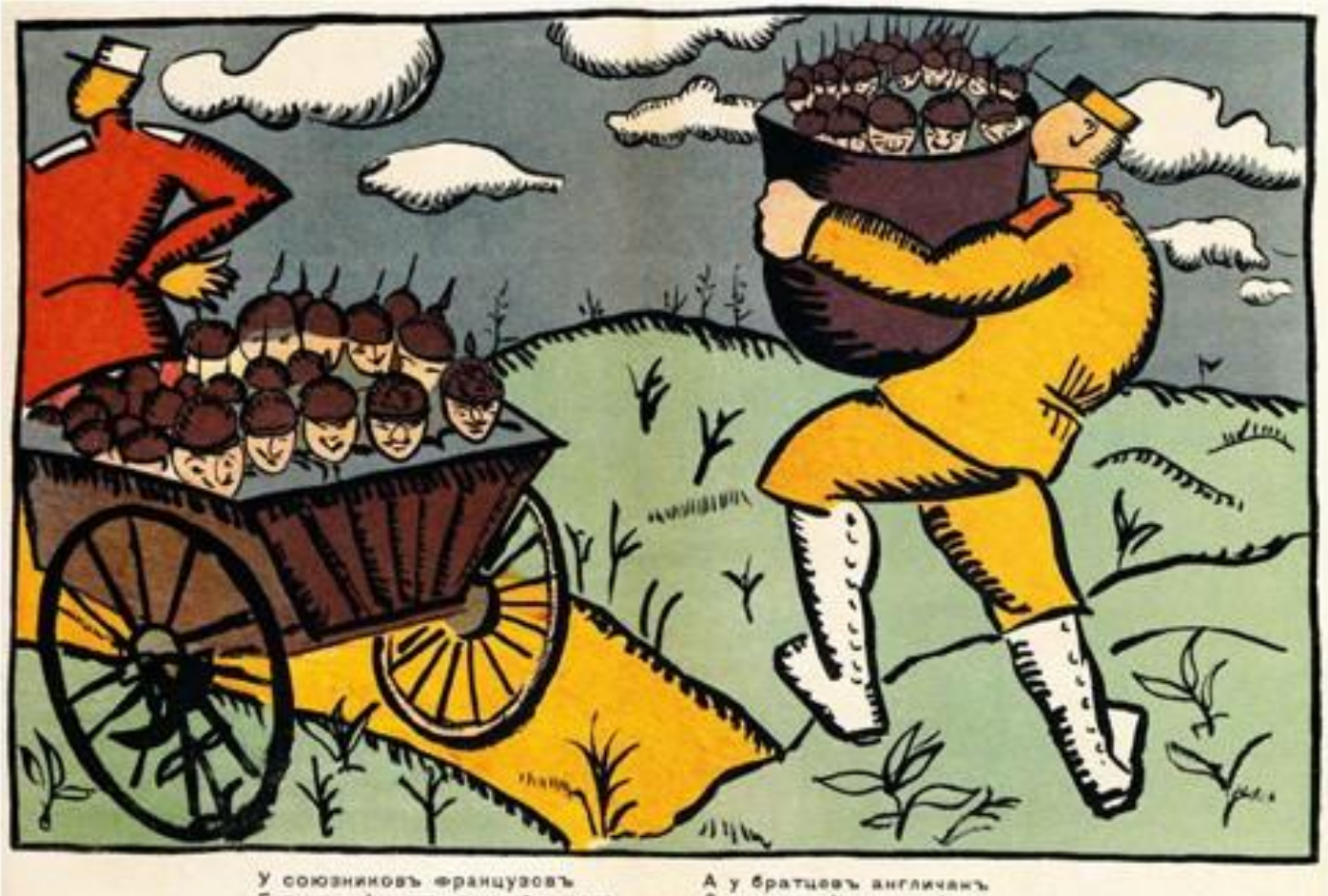

Fonte: Melton Prior Institute e Russian culture. 
Figura 6 - K. Maliévitch: Pedicuro no Banheiro - 1908-1909

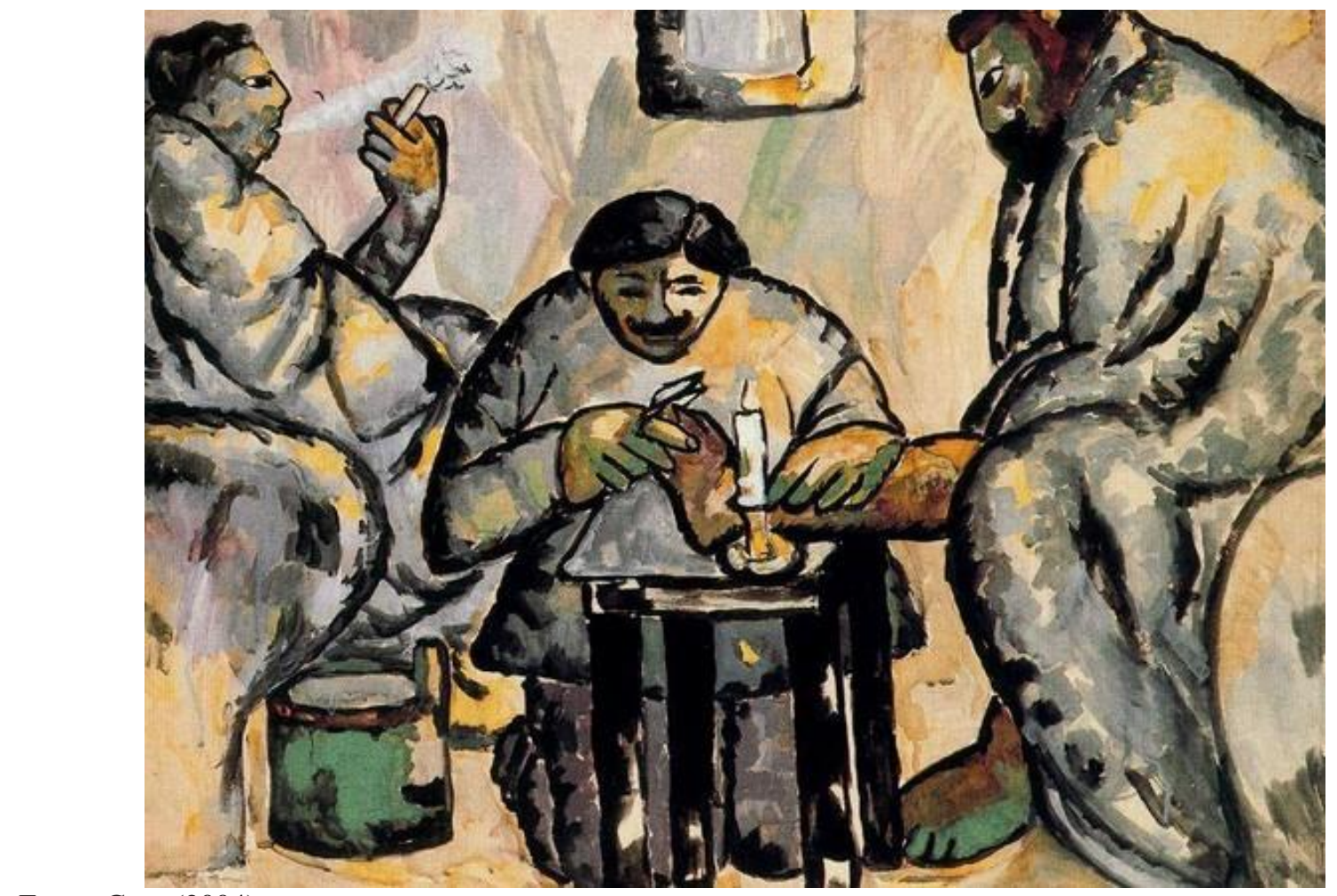

Fonte: Gray (2004).

Figura 7 - P. Cézanne: Os Jogadores de Cartas - 1890-1892

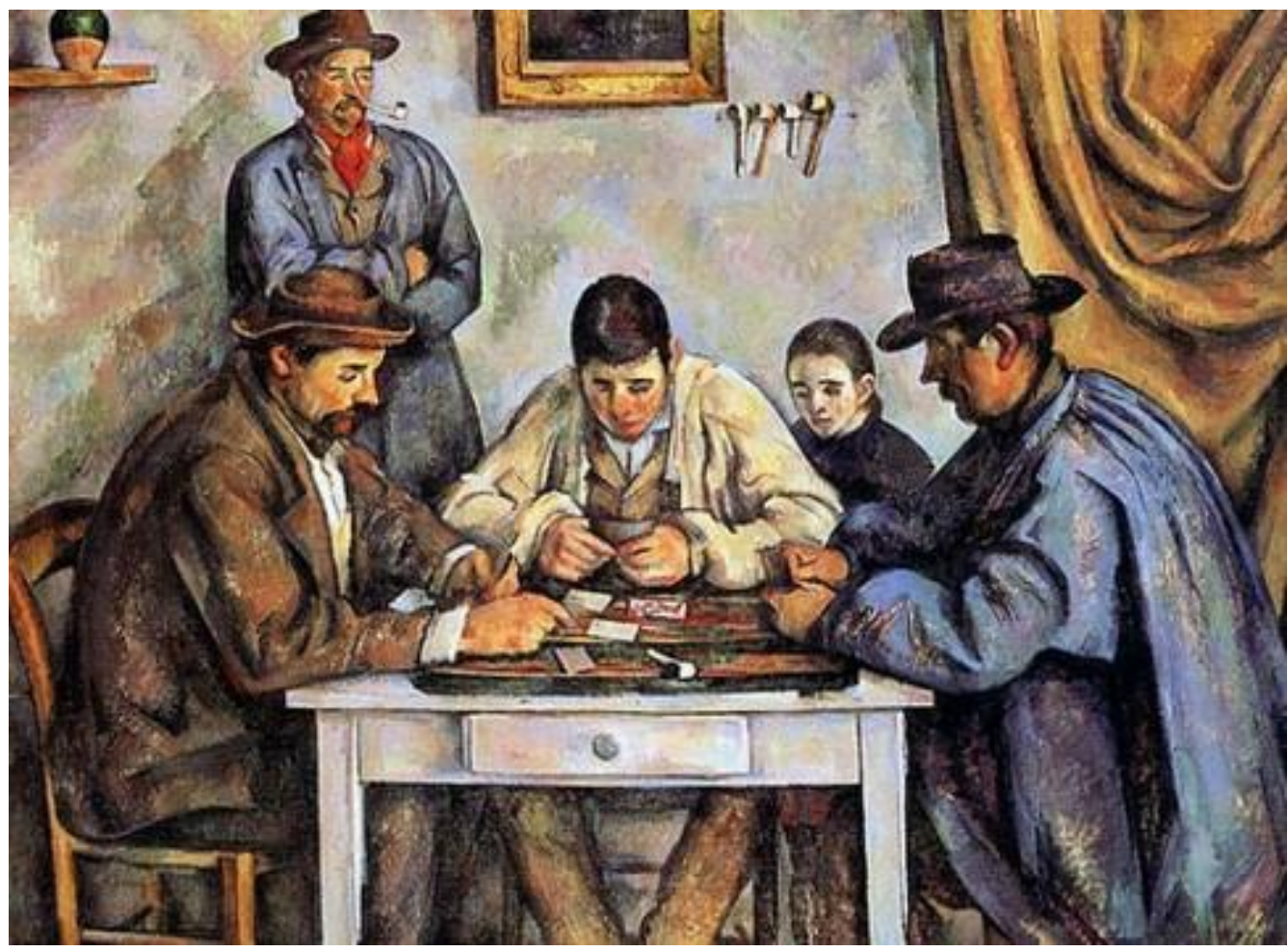

Fonte: Gray (2004). 


\section{TRAJETÓRIA ARTÍSTICA DE MALIÉVITCH}

Maliévitch nasceu em 1878, numa cidade próxima a Kiev (Ucrânia), e faleceu em 1935, em São Petersburgo, na Rússia. Sua mãe era de origem camponesa e seu pai um proletário industrial. Em 1896, sua família muda-se para Kursk, onde integra-se a uma comunidade de artistas e trabalha como desenhista técnico. Tinha uma grande inteligência intuitiva e trabalhava com velocidade e concentração, até chegar a uma conclusão. Era um orador brilhante e bemhumorado, embora fosse reservado sobre sua vida pessoal. Chegou a Moscou em 1905, aos 27 anos, e, apesar de não ter frequentado a Faculdade de Moscou, trabalhou no estúdio de Roerburg, considerado o principal vanguardista da época (SIMMEN; KOHLHOFF, 2001).

Para Maliévitch, a pintura moderna poderia ser dividida em "sistemas": o impressionismo, o cezannismo, o cubismo e o futurismo. Cada sistema carrega suas respectivas características, e a compreensão desses sistemas pictóricos serviriam de fundamento para se chegar ao Suprematismo. Ao observar obras impressionistas de Monet, Maliévitch ficou fascinado com a ausência de profundidade e a estrutura cromática. Monet pintou diversas vezes a Catedral de Rouen e em cada pintura notamos interferências da luz que variam de acordo com o horário e as condições climáticas. Segundo o artista, Monet não estava preocupado com a luz e a sombra da Catedral, mas sim com a pintura que se encontrava na luz e na sombra. Podemos perceber nas pinturas The Portal and the Tour d'Albane (Figura 8) e Rouen Cathedral (Figura 9) o predomínio do branco, ora representando um inverno rigoroso, comum aos europeus, ora representando o brilho da luz do sol sobre a superfície. A percepção de Maliévitch sobre essas obras era completamente diferente da do público. Defendia a ideia de que o artista quando pinta um objeto, um elemento, a intenção é que este objeto se perca, para assim ressaltar a pintura, e não o contrário, que seria a busca da semelhança com a realidade (MALIÉVITCH, 2007). 
Figura 8 - C. Monet: The Portal and the Tour d'Albane (Morning Effect) - 1892

Fonte: Wildenstein (2003).

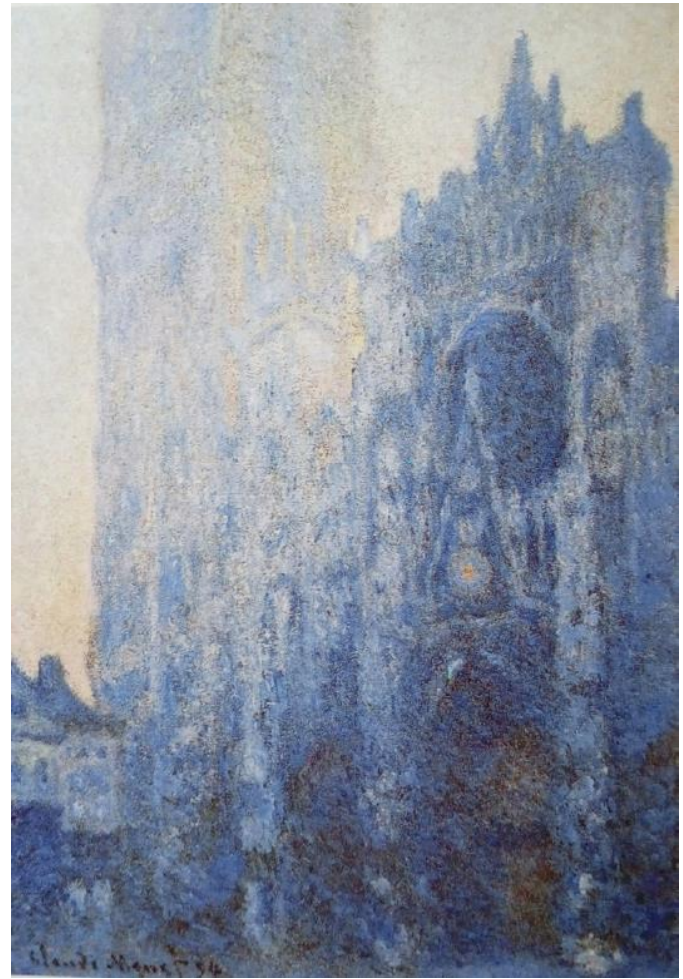

Figura 9 - Monet: Rouen Cathedral - 1892

Fonte: Wildenstein (2003).

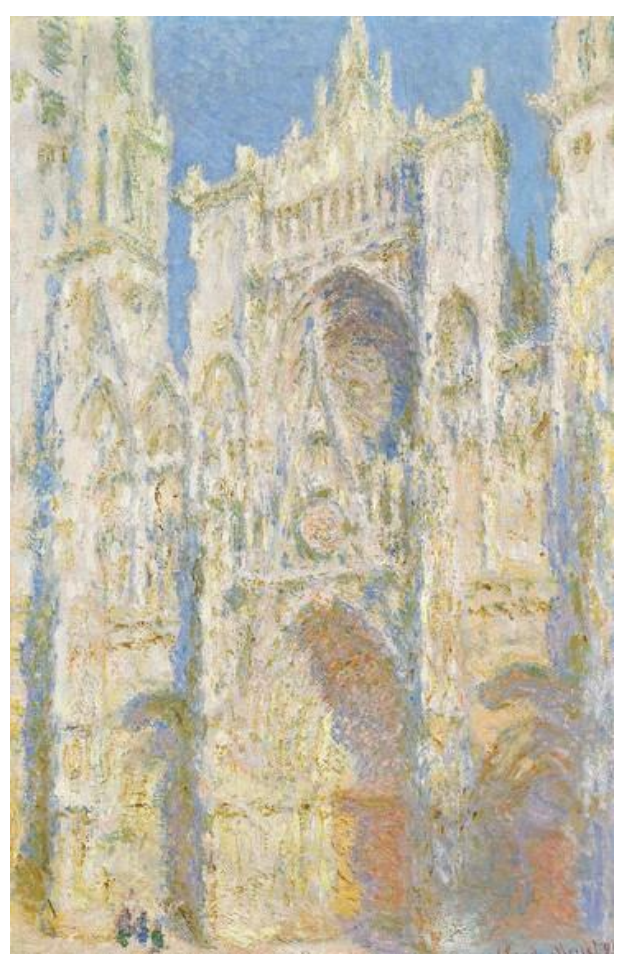


Na obra Paisagem com Casa Amarela (Figura 10), observamos a presença de uma "massa de cor", com o predomínio de cores primárias, e uma casa ao fundo quase dissolvida entre linhas verticais, construída com manchas e ausência de profundidade, que proporcionam uma generosa luminosidade. Podemos notar com facilidade interferências impressionistas, em especial, nesse caso, a série Catedral de Rouen, de Monet.

Sobre a obra Paisagem com Casa Amarela:

À minha frente, entre as árvores, estava uma casa recém-caiada. Era um dia de sol. O céu estava azul cobalto. Um lado da casa permanecia à sombra, o outro estava iluminado pelo sol. Pela primeira vez apercebi-me do claro reflexo do céu azul, dos tons puros e transparentes. A partir desse momento passei a pintar com cores claras e luminosas. A partir desse momento tornei-me um impressionista (MALIÉVITCH, 1930 apud SIMMEN; KOHLHOFF, 2001, p. 17).

Figura 10 - K. Maliévitch: Paisagem com Casa Amarela - 1906-1907

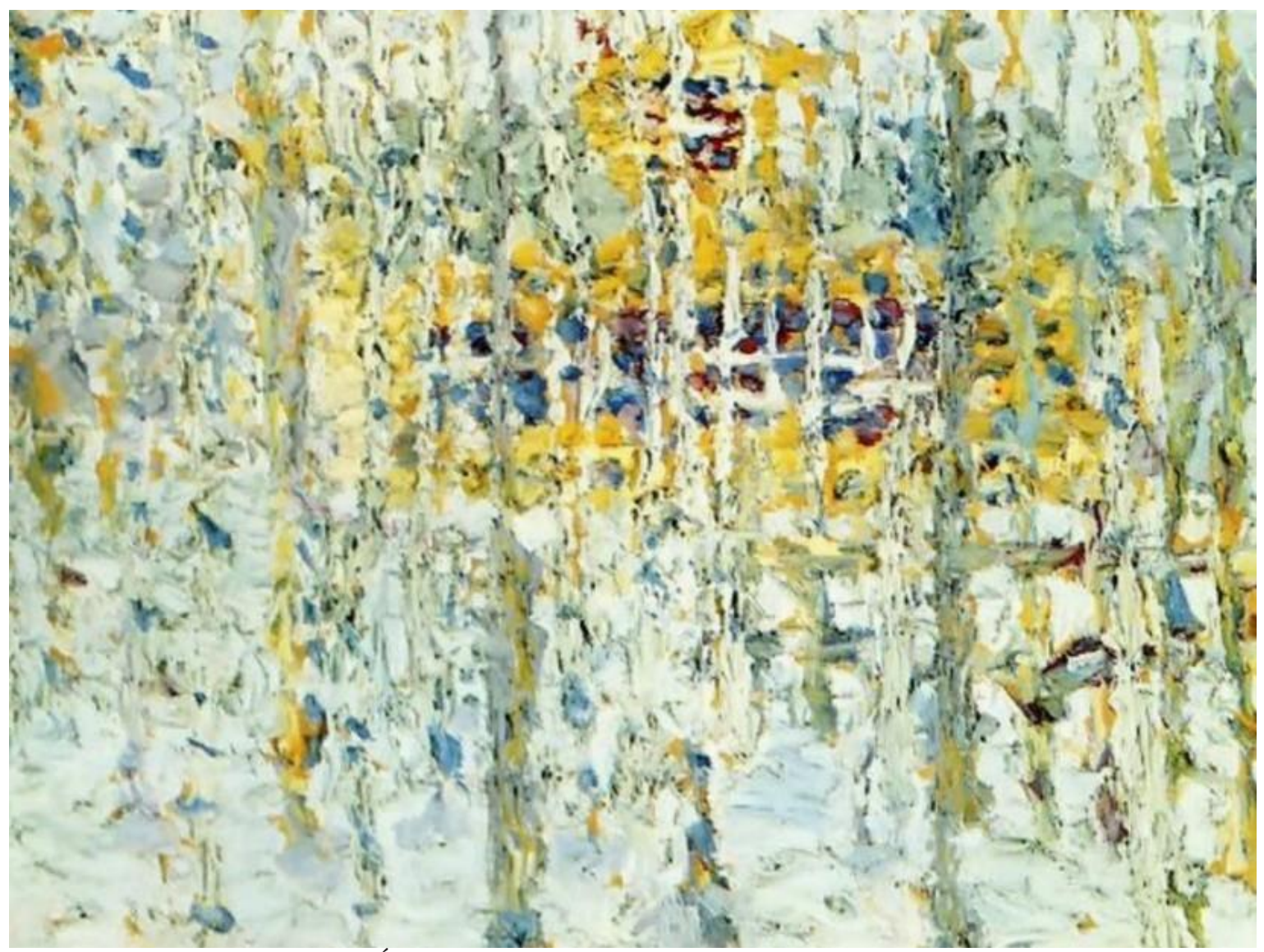

Fonte: Simmen e Kohlhoff (2001). Óleo sobre cartão. 19,2×29,5cm. Museu do Estado Russo, São Petersburgo.

Maliévitch não se preocupava com a natureza ou com a análise das impressões visuais e individuais, mas sim com a relação do homem com o cosmos. Diferentemente dos impressionistas franceses, Maliévitch não trabalhava com a intenção de demonstrar pontos luminosos. O artista ressaltava o intercâmbio com a atmosfera, situando as luzes como 
consequência das próprias cores sobrepostas. Na pintura Garota das Flores (Figura 11), exibida na mostra do grupo "Valete de Ouros" em 1910, o artista posiciona uma moça num primeiro plano e a paisagem em segundo plano. A cena do fundo é feita com pinceladas leves e impressionistas, retratando um ambiente parisiense. A figura feminina é contornada por um traço linear e contínuo e nos dá a sensação de "achatamento", eliminando a perspectiva tridimensional. Apesar de seguir uma proposta do Impressionismo, um retrato do imediatismo, a figura retratada, no caso uma moça, apresenta uma certa rigidez. Com relação às cores, há o predomínio de cores primárias. Nos trabalhos figurativos, o artista retratava o indivíduo de modo peculiar. Suas características faciais (fisionomia) não têm importância, pois o indivíduo tinha a "função" de representar o coletivo. As figuras humanas eram tidas como símbolos da humanidade.

Com relação a essa questão, o próprio artista afirma:

Quase nunca conseguimos ver o rosto das pessoas; e quando perguntamos a alguém quem ele é, temos como resposta: "engenheiro", "fazendeiro", etc., ou seja, obtemos a descrição do papel que é representado por estas pessoas neste ou naquele espetáculo dos sentimentos (MALIÉVITCH apud CHIPP, 1999, p. 348).

\section{Figura 11 - K. Maliévitch: Garota das flores - 1904-1905}

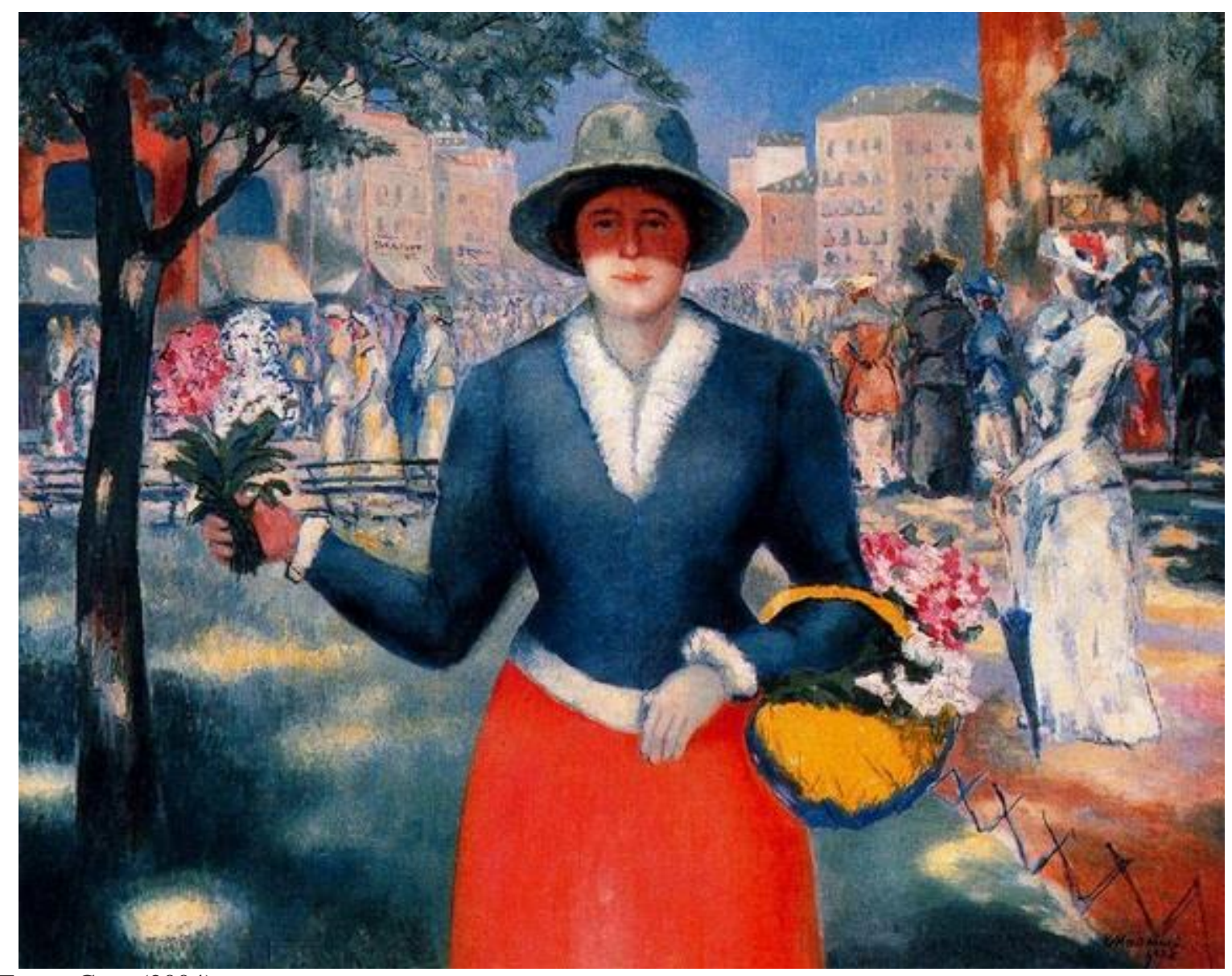

Fonte: Gray (2004). 
Em 1907, Maliévitch realizou uma série com o título Estudo para um afresco (Figuras 12 e 13) e expôs pela primeira vez na Associação de Artistas de Moscou. Podemos observar fortes influências pós-impressionistas, simbolistas e do Grupo Nabis ${ }^{9}$, a presença da temática religiosa e da busca por uma introspecção, associada a um tom místico. Na Figura 12, o rosto do artista ocupa o primeiro plano como se fosse o redentor, que veio para "salvar" os aflitos do segundo plano. As cores são utilizadas de modo emocional, com o predomínio de cores complementares, no caso vermelho e verde. Em ambas as figuras, as linhas são distorcidas. Notamos aqui uma tendência de que, em suas obras futuras, será mais esclarecida a característica de o artista cumprir o papel de profeta, de carregar a missão de comunicador entre o mundo físico e espiritual.

Figura 12 - K. Maliévitch: Estudo para um afresco (autorretrato) - 1907

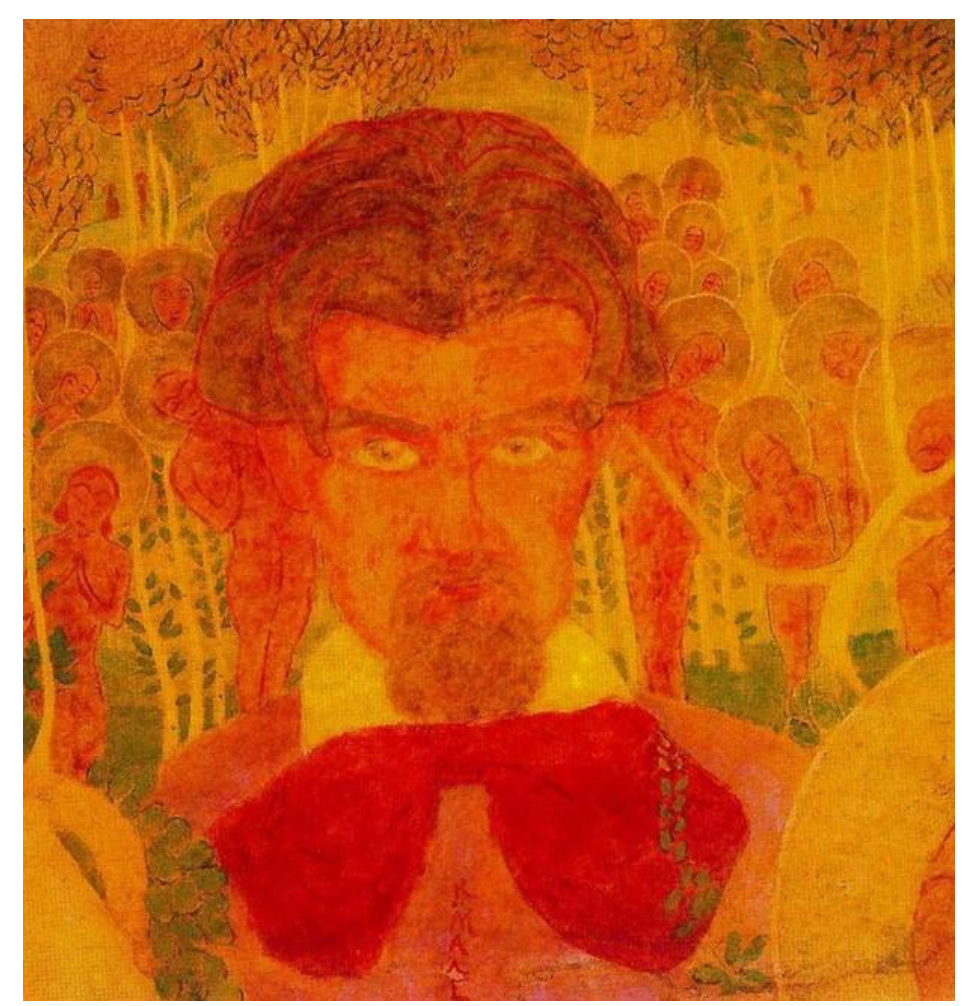

Fonte: Simmen e Kohlhoff (2001). Guache sobre cartão. 69,3x70cm. Museu do Estado Russo, São Petersburgo.

\footnotetext{
${ }^{9}$ O Grupo Nabis foi uma irmandade secreta, fundada em 1888 por artistas e teóricos franceses que eram contra o academicismo e o naturalismo e defendiam ideias próximas aos Simbolistas (DEMPSEY, 2008).
} 
Figura 13 - K. Maliévitch: Estudo para pintura de afresco - 1907

Fonte: Bermejo (1995).

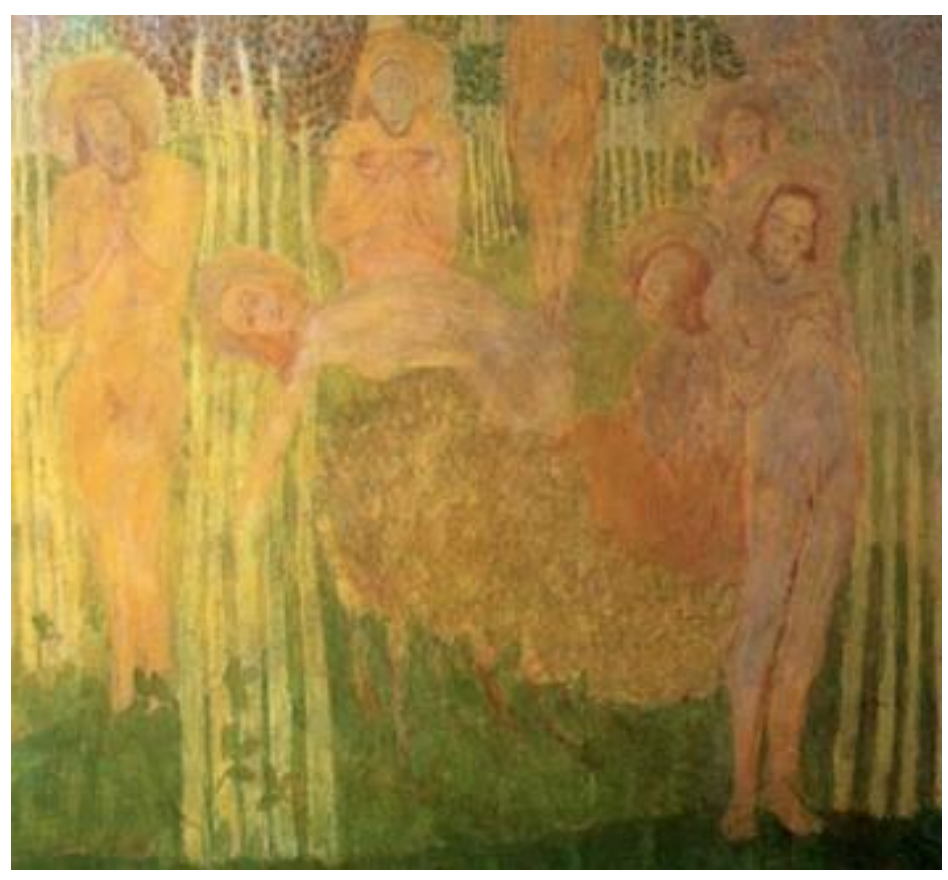

Na pintura Repouso. Sociedade de Cartola (Figura 14), considerada sua obra mais decorativa, Maliévitch não retrata a natureza ou a atmosfera que envolve as pessoas, como no Impressionismo. Ao contrário, não há interação entre as figuras, que são construídas sobre um plano verde, com ausência de sombras e profundidade, criando um ritmo aleatório. A única relação que as pessoas mantêm entre si é percebida somente pelas roupas das figuras femininas com a mesma cor. Na pintura A Sala Vermelha (Figura 15), de Henri Matisse, encontramos características semelhantes em relação ao Repouso. Sociedade de Cartola. Assim como Matisse, Maliévitch construiu os elementos composicionais do quadro com a cor. Há também uma ausência de perspectiva, mas de algum modo notamos diferentes planos, embora de modo chapado. Outra analogia é que ambos trabalham fortemente com cores complementares. Apesar da proximidade pictórica entre as duas obras, há alguns diferencias entre as respectivas pinturas. Enquanto Matisse pintou sua obra para uma espécie de apreciação burguesa, Maliévitch retratou uma cena comum da burguesia parisiense com um tipo de crítica e ironia social à mesma burguesia. Em Repouso. Sociedade de Cartola, notamos a ausência de interação entre indivíduos, e, para reforçar essa ironia, um homem, na parte superior do quadro, apresenta uma atitude inadequada para um local público. 
Figura 14 - K. Maliévitch: Repouso. Sociedade de Cartola - 1908

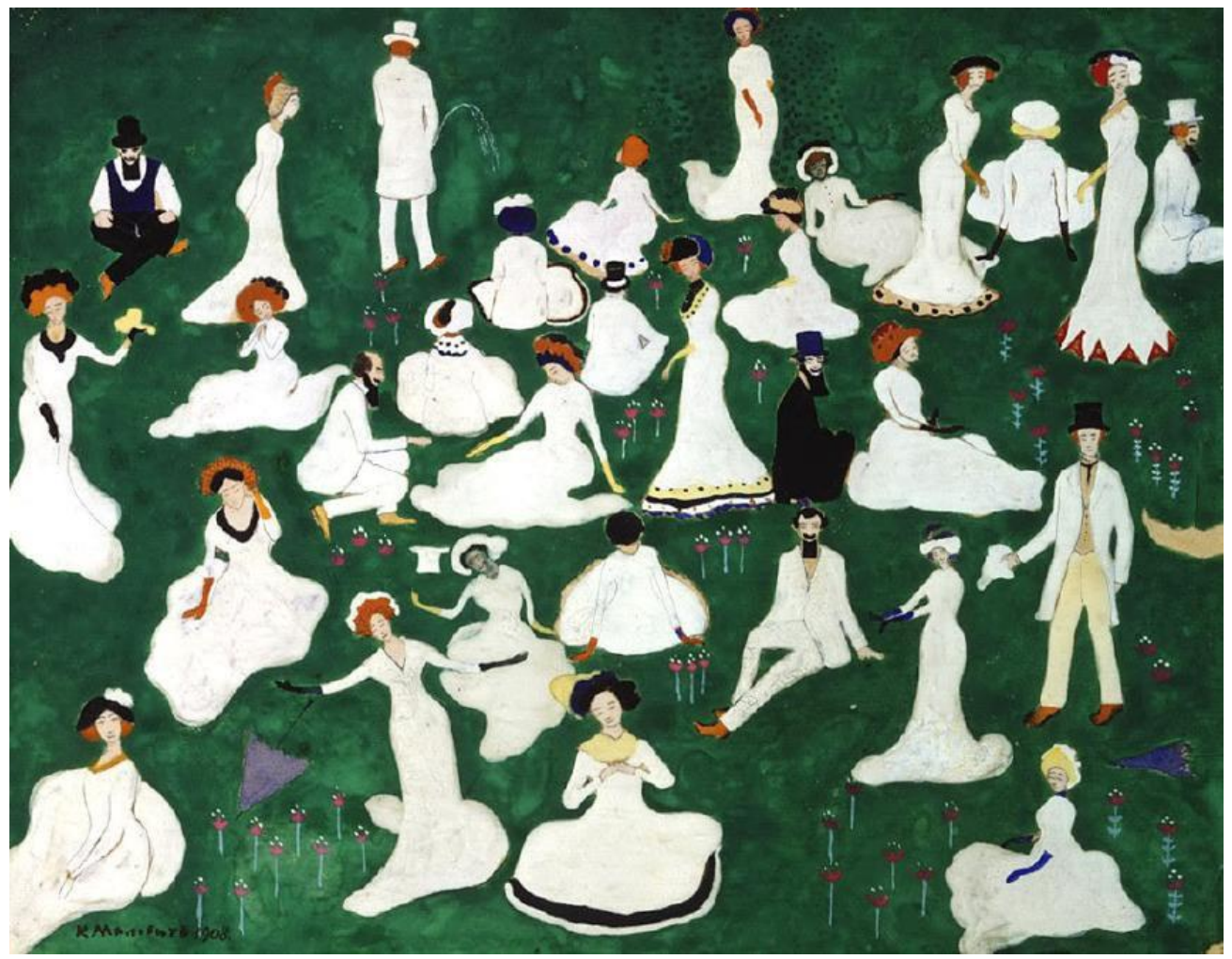

Fonte: Aguilar, 2002. Têmpera sobre papel. 24,5x30,5cm.

Figura 15 - H. Matisse: A Sala Vermelha - 1908-1909

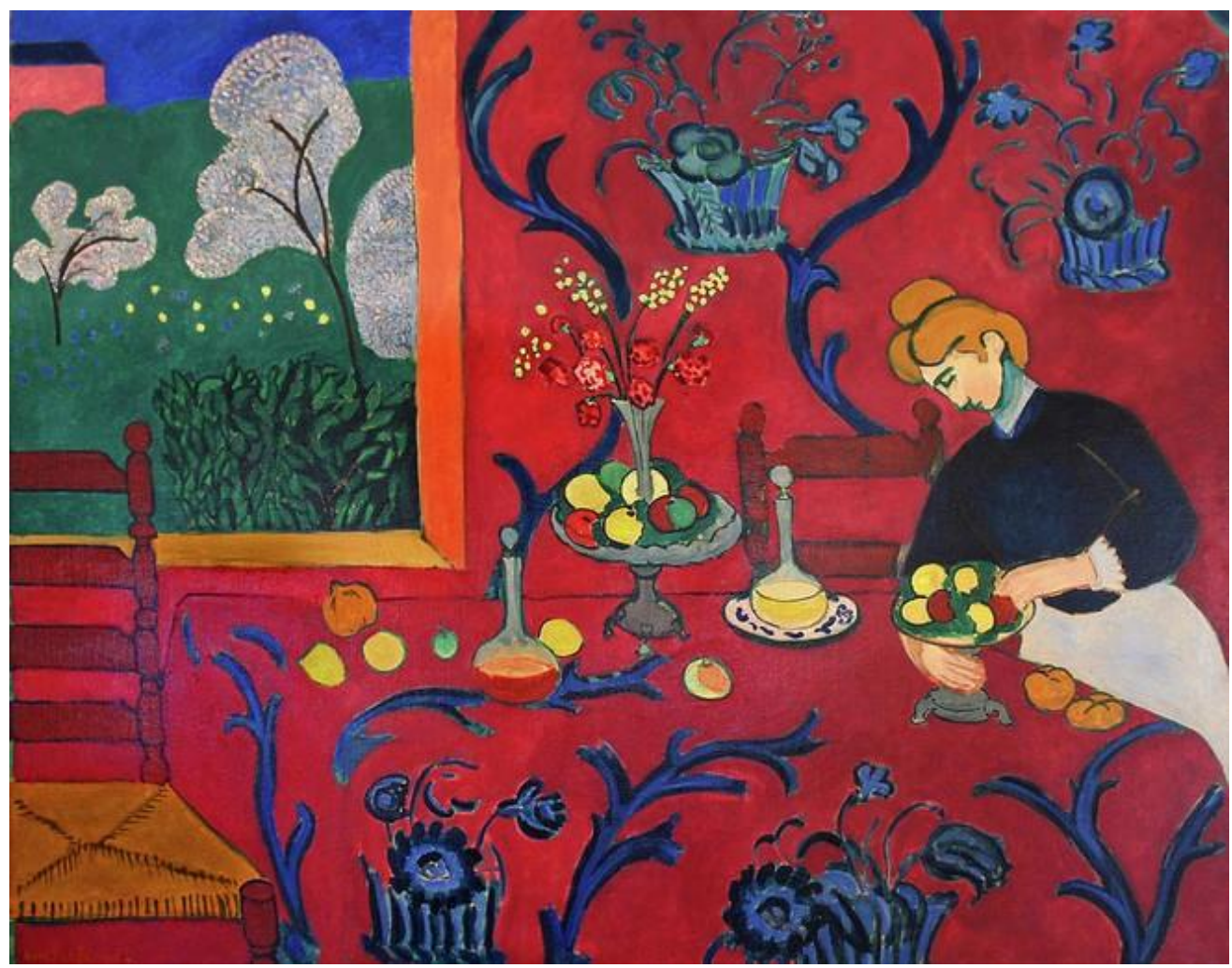

Fonte: Gombrich (1999). 1,81x2,46m. Museu Hermitage, Leningrado. 
Podemos notar, analisando o conjunto das obras de Maliévitch, uma fase de seus trabalhos que sofreu fortes influências de Cézanne, que tinha um estilo formal de pintar, com um ritmo de pinceladas que era uma de suas marcas registradas. Cézanne pintava a natureza de acordo com sua percepção pessoal, seguindo determinada lógica racional. Maliévitch tinha uma percepção de alguns termos utilizados para rotular uma característica artística, como, por exemplo, o "primitivismo". O artista, quando falava-se que a obra de Cézanne e até mesmo a de Gauguin eram relacionadas ao "Primitivo", argumentava que a arte não parava de evoluir, assim como o mundo, e, sendo assim, não havia como um pintor moderno ter aspirações primitivas, pois isso já havia passado. $\mathrm{O}$ artista defende que Gauguin foi ao Taiti porque foi o caminho que ele encontrou para apresentar as cores que ferviam dentro de si. Com relação a Cézanne, para Maliévitch, o que é chamado de "primitivo" foi a aspiração que o pintor teve em relação à redução do modelo com a exemplificação de formas geométricas (MALIÉVITCH, 2007).

Com relação a isso:

Quero ser um fazedor de novos signos de meu movimento interno, pois dentro de mim está o caminho do mundo [...] As obras de Cézanne estão relacionadas com o primitivo, mas ele não pensava e não construía suas obras primitivamente ou sem habilidade; conhecia o pré-histórico, os clássicos, os pseudoclássicos, os realistas, os impressionistas, e sabia sobre quais fundamentos deveria edificar seu trabalho (MALIÉVITCH, 2007).

Na obra Banhistas (Figura 16), notamos a busca temática pelos clássicos, como na pintura Grandes Banhistas, de Cézanne (Figura 17). As figuras, em ambas as obras, encontram-se no primeiro plano, e no fundo há a presença da natureza pintada com um ritmo similar de pinceladas nas duas obras. Em Cézanne, os rostos possuem uma identificação formal e não pessoal, enquanto em Maliévitch não há rostos - notamos que o anonimato facial continua e que a ideia de retratar um indivíduo como alguém que pertence a um sistema permanece. 
Figura 16 - K. Maliévitch: Banhistas - c. 1908

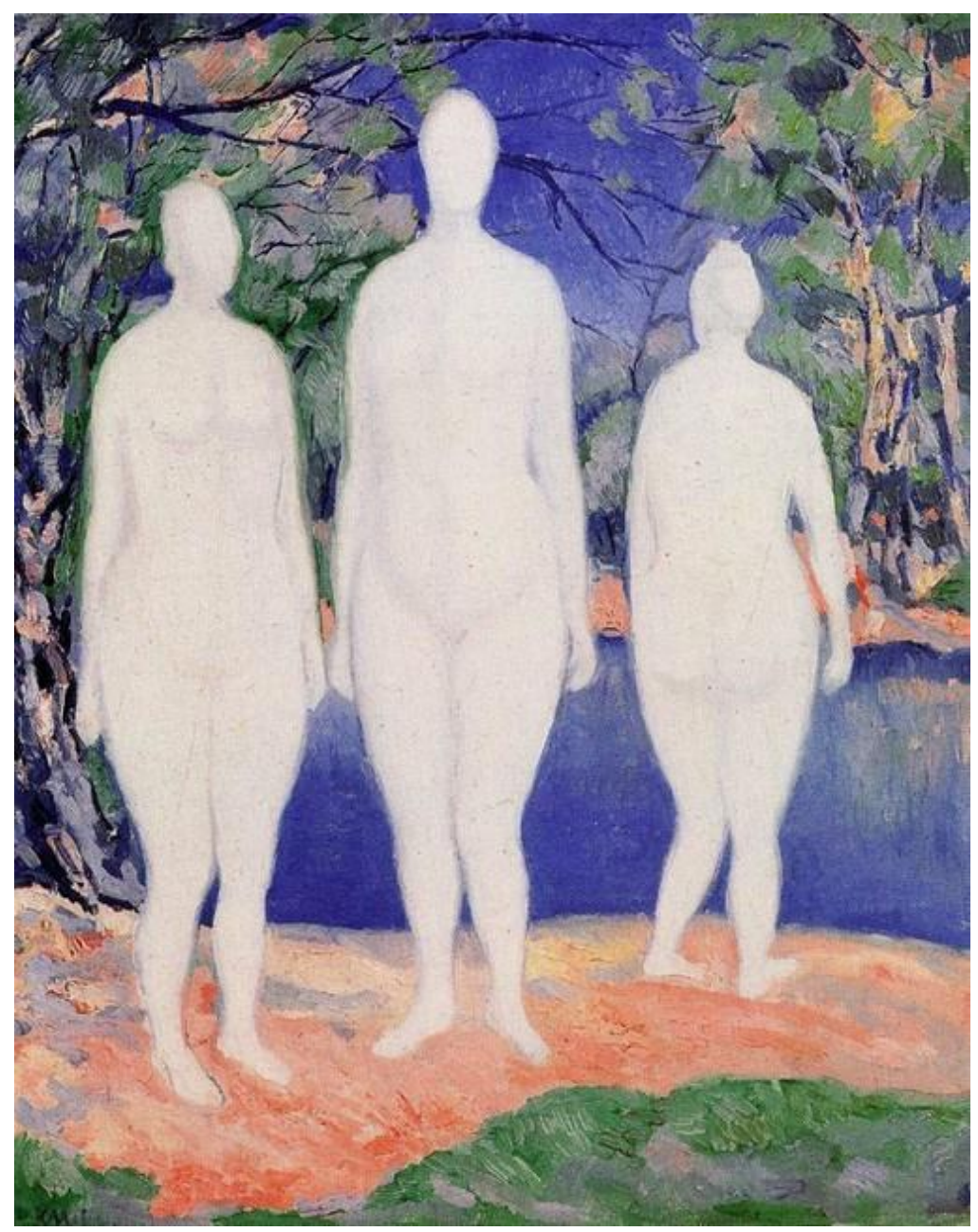

Fonte: Bermejo (1995).

Figura 17 - P. Cézanne: Grandes Banhistas - 1900-1906

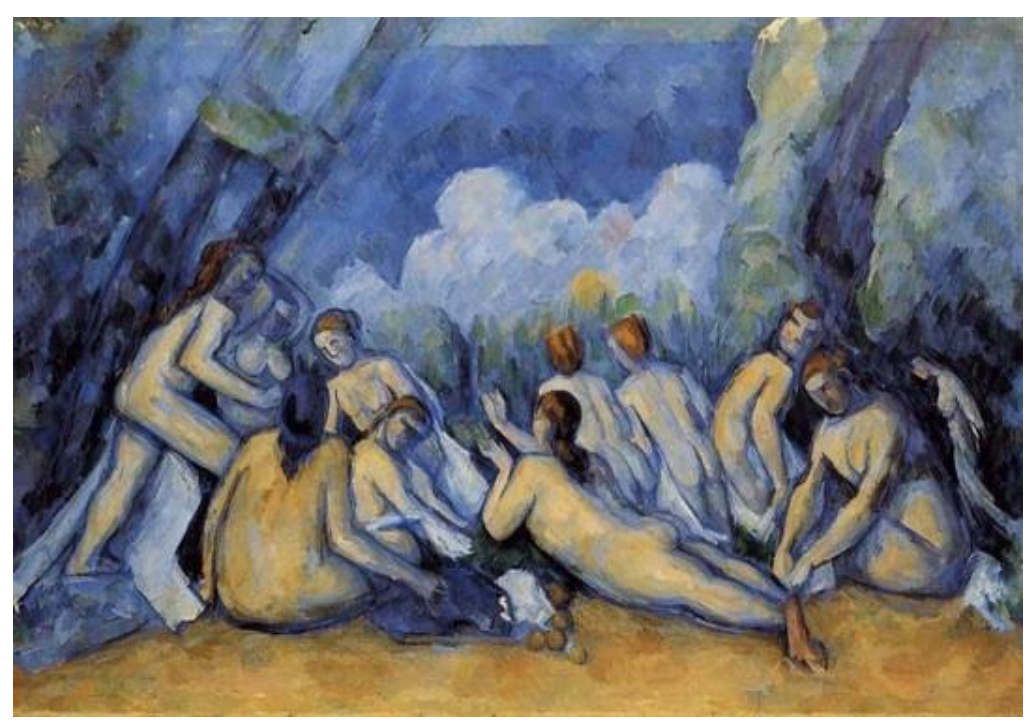

Fonte: Harris (1982). 
Em 1911, Maliévitch inicia em suas pinturas uma tentativa de afastamento de aspectos representativos e também abandona imagens estáticas. A vanguarda russa sofre influência do então já rotulado "Primitivo". Na obra Banhistas (Figura 16), as influências cézannianas continuam presentes na construção das pinceladas e na ausência de perspectiva. Apesar das figuras não se apresentarem de modo estático, há todo um peso na forma. A escolha cromática é utilizada sem timidez, e as banhistas são pintadas com cores que não retratam a cor de um corpo real. Tanto nos banhistas como no fundo há o mesmo tipo de tratamento. A construção com manchas e o uso de cores escolhidas aleatoriamente, sem a preocupação com a cor do suposto modelo, são características herdadas do Fauvismo. Em 1910, Matisse atende a uma encomenda de um colecionador russo e pinta A Dança (Figura 18). Apesar de notarmos influências de Matisse, Maliévitch não o copia, constrói a obra de acordo com sua visão artística, como em Banhistas (Figura 19). Na pintura No Bulevar (Figura 20), notamos novamente características "primitivistas" e influências fauve: estão presentes as manchas de cores e o forte e sem ritmo contorno; a relação figura-fundo continua sem perspectiva, apesar de notarmos as diferenças de planos; para o tema o artista escolheu um operário (proletário urbano) com aparência de desolado e frustrado, com mãos volumosas que produzem um aspecto de trabalhador braçal. Vale ressaltar que o pai de Maliévitch foi um operário em refinarias de açúcar.

\section{Figura 18 - H. Matisse: A Dança - 1910}

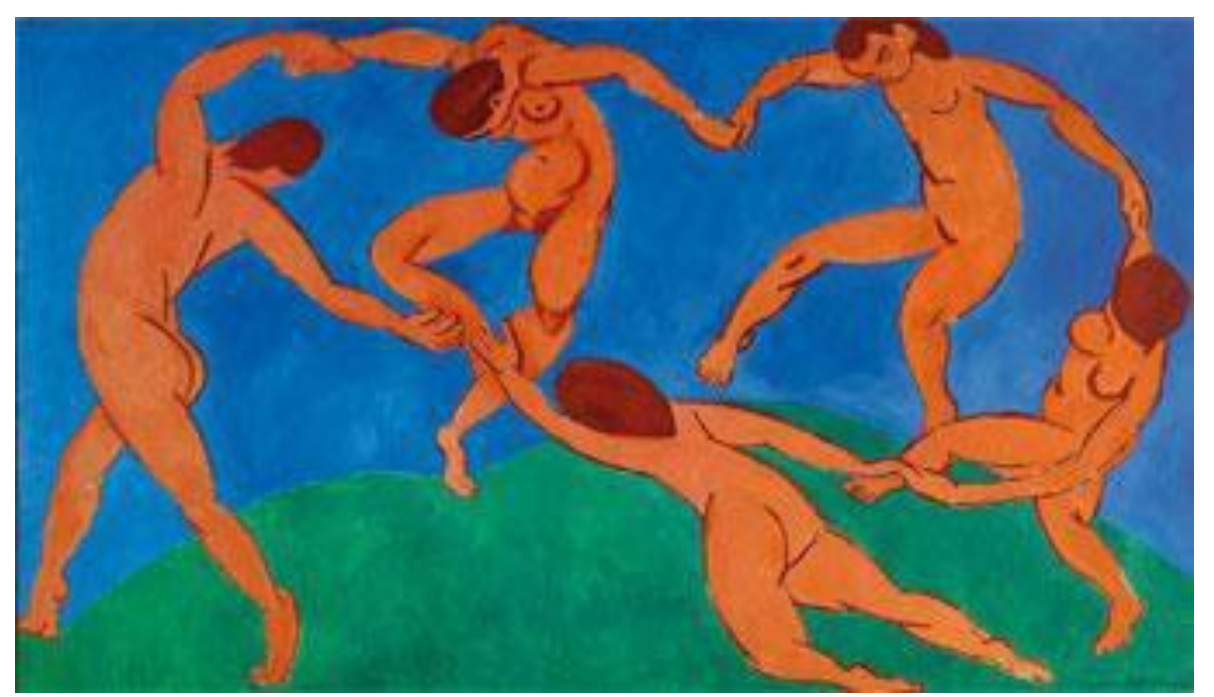

Fonte: Argan (1992). 2,60x3,90m. Museu Hermitage, Leningrado. 
Figura 19 - K. Maliévitch: Banhistas - 1911

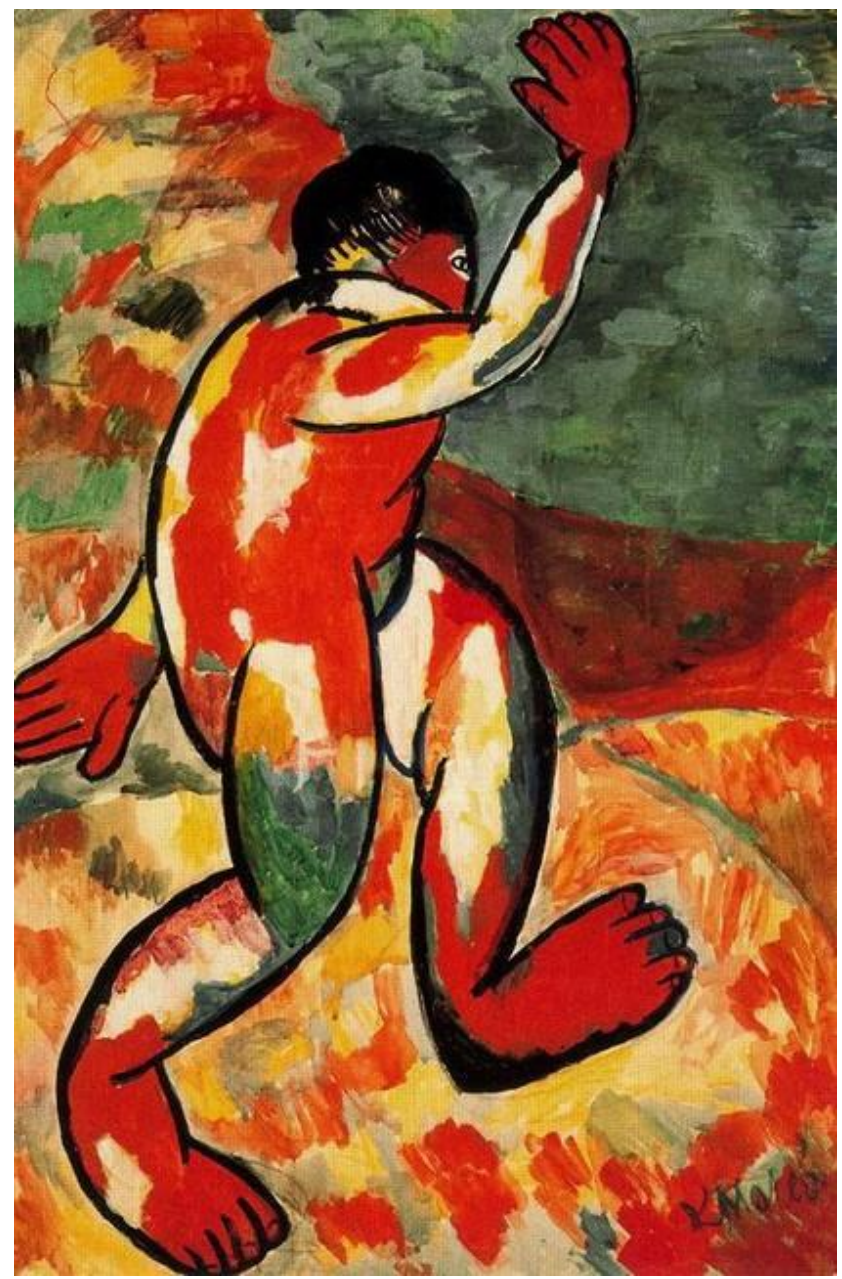

Fonte: Simmen e Kohlhoff (2001). Técnica mista sobre papel. 105x69cm. Stedelijk Museum, Amsterdã. 
Figura 20 - K. Maliévitch: No Bulevar - 1911

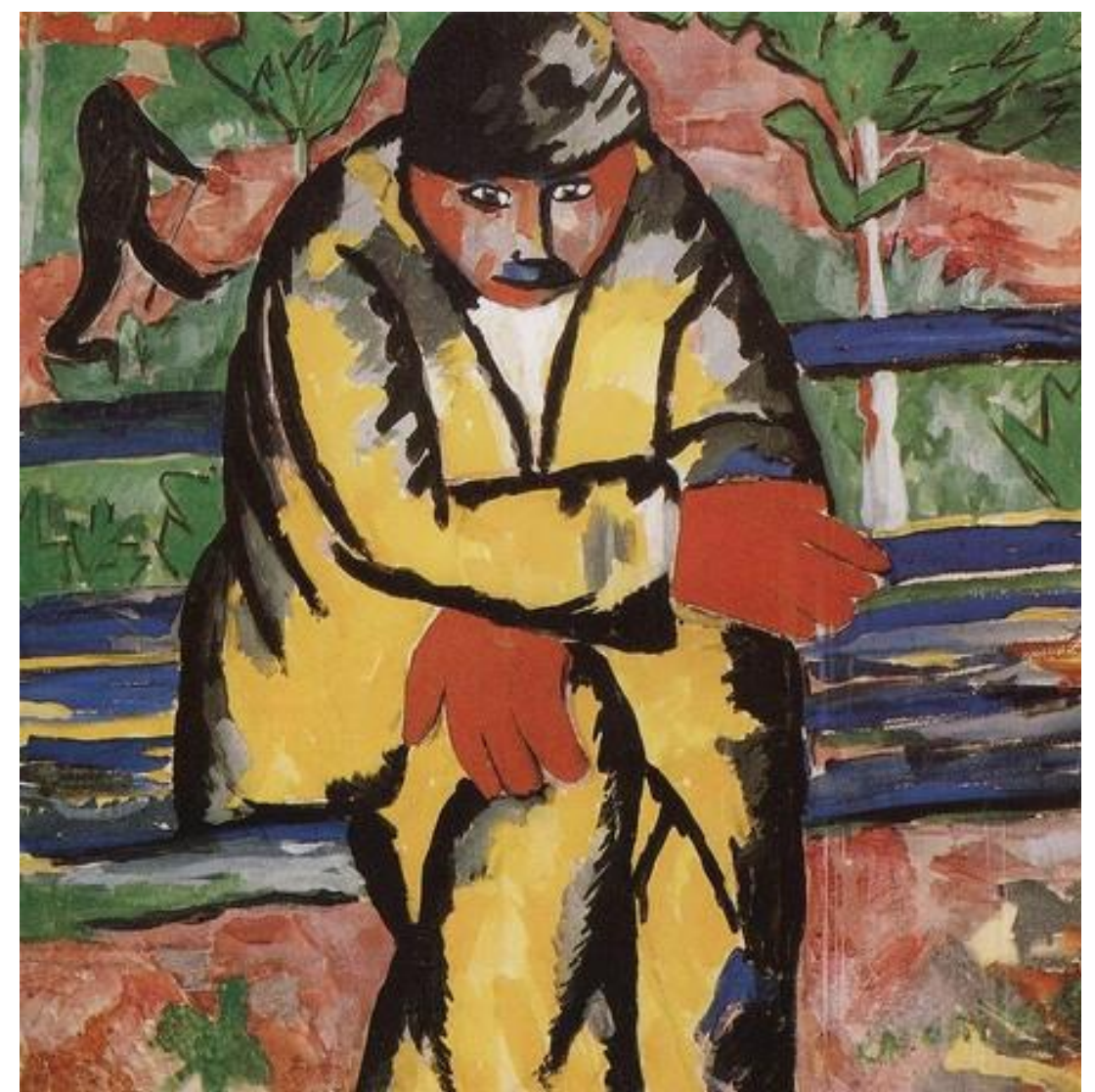

Fonte: Harrison, Frascina e Perry (1998). Guache sobre papel. 72x71cm. Stedelijk Museum, Amsterdã.

Nas pinturas No Bulevar e Camponesa com baldes e criança, respectivamente (Figuras 20 e 21), notamos duas diferentes vertentes do "Primitivismo" adotado por Maliévitch. No primeiro caso, há influências fauvistas na cor, com técnica a guache e pinceladas ásperas e soltas. O tema, um operário (proletário urbano) desolado, frustrado, com pés e mãos volumosos, pode ter chamado a atenção do artista pelo fato de seu pai ter sido um operário em refinarias de açúcar. No segundo caso, percebemos a presença do formalismo cézanniano, já caminhando para o cubismo. Os olhos apresentam-se estrábicos e em formato de amêndoas - como nos ícones tradicionais. As faces profundas e as feições pesadas ganham mais ênfase; as mãos e pés alargados achatam as figuras contra a superfície da tela e o fundo isola as duas figuras estáticas. O contorno marcado No Bulevar foi substituído por pinceladas suaves e delicadas em uma superfície mais lisa, com tinta a óleo.

Na pintura Camponesa com baldes e criança (Figura 21), podemos observar várias influências adotadas por Maliévitch. Nessa pintura, há uma espécie de junção de vertentes europeias que estavam em ascensão. Percebemos a presença do formalismo cézanniano: a relação figura-fundo continua apresentada de modo plano; do primitivo: proposta temática, pés e 
mãos apresentados de modo grotesco, faces profundas com feições pesadas; do cubismo: as formas são construídas de modo estilizado e anguloso; do Futurismo: volumes apresentados por meio da construção de luz e sombra. Os olhos apresentam-se de modo estrábico e com formato de amêndoas - como nos ícones tradicionais.

\section{Figura 21 - K. Maliévitch: Camponesa com baldes e criança - 1912}

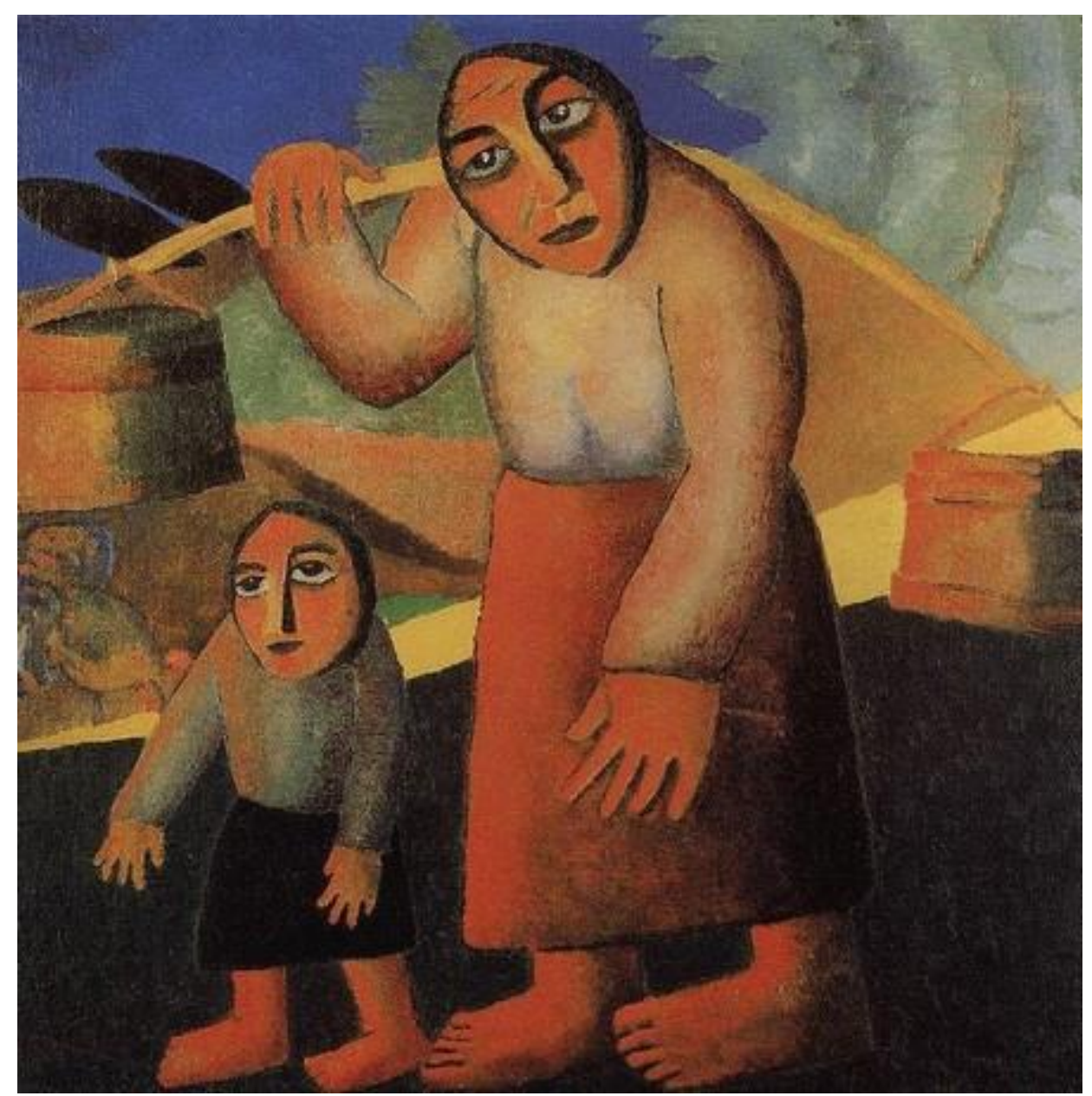

Fonte: Bermejo (1995).

Através dos fundamentos de Cézanne, a arte que até então seguia um padrão de semelhança, adquire vida nova, desencadeando o processo do cubismo. Maliévitch defendeu que a força do cubismo não estaria na representação pictórica e detalhada da plenitude da imagem, mas sim na "pulverização", termo adotado por Nikolai Berdiaév que remete à dissipação da imagem. O pintor afirma que os artistas perceberam que o objeto não era representado de modo pleno, e com a proposta cubista a revelação do espaço adquiriria uma nova harmonia com a utilização de um novo sistema de construção, que negava a repetição de formas idênticas para evitar o enfraquecimento da tensão na construção, e combinações superficiais do modelo acadêmico. Apesar do grande salto artístico cubista por apresentar um trabalho pictórico que 
rejeite a verossimilhança, Maliévitch questionava o cubismo pelo fato de os artistas terem como foco principal a apresentação de um objeto utilizando apenas três dimensões. $\mathrm{O}$ artista acreditava que um objeto poderia ter mais do que três dimensões, e essas regras academicistas, mesmo que aparentemente inovadoras, acabariam por limitar o artista. Finalmente, a valorização da cultura pictórica começa a ganhar espaço.

Com relação a isso, o artista diz:

Foi a aspiração da razão como guardiã da lógica que, como um soldado, postase na entrada e teme que dentro da arte aconteça algo de não natural, pois crê tão piamente que tudo que se desenha a partir do modelo é natural [...] (MALIÉVITCH, 2007, p. 45).

Com relação ao Futurismo, Maliévitch acreditava que este Movimento fora de extrema importância para a pintura. $\mathrm{O}$ artista concluiu que, assim como Cézanne proporcionou o início do Cubismo, Van Gogh deu início às primeiras propostas futuristas, mesmo que de modo inconsciente ao notar que tudo no mundo tremula como consequência do movimento uno universal. Para o artista, o Futurismo Dinâmico negou tudo que é verde e de carne e osso, para dar espaço ao "movimento". O que importa para o Futurismo é a velocidade, o dinamismo, o mundo que gira incessantemente. Como consequência desse movimento, naturalmente nos serão apresentadas novas questões e soluções. Para o Futurismo, não importa o modelo do objeto ou da máquina, pois eles são meros símbolos que expressam a velocidade da dinâmica. Sobre isso o artista afirma:

O ser humano formou um centro, ao redor do qual ocorre o movimento e esclareceu que tal fenômeno não ocorre somente dentro de um único ponto de fuga cuneiforme, mas está também na frente e atrás, dos lados, acima, abaixo [...] (MALIÉVITCH, 2007, p. 72).

O Futurismo carregava uma proposta de ordem social, além de ser um movimento artístico. Era defendido como um modelo de rejeição ao provincianismo e também como um modo de expressar a intolerância com o conservadorismo cultural. Trazia também como ideia retirar o burguês da zona de conforto a que estava acostumado. Uma afirmação para um mundo novo, modernizado. Sobre isso o artista afirma:

[...] é evidente que para o pequeno-burguês, acostumado a ver algumas carruagens e mais precisamente uma carruagem, é difícil compreender o novo movimento de massa da cidade, no qual todas as representações servem na medida em que sua forma é necessária, como uma interação de contrastes, para o aumento da expressão do dinamismo (MALIÉVITCH, 2007, p. 73).

Nas obras Lenhador e Ceifeiro (Figuras 22 e 23), notamos influências que eram denominadas pelo próprio artista como cubo-futuristas. A figura e o fundo são construídos por elementos geométricos, e a pintura lembra uma superfície de metal. Podemos verificar parte 
dessa influência futurista na obra A mulher de Azul (Figura 24), de Fernand Léger. No Lenhador, o tempo ainda está associado ao espaço; o lenhador parece estático. Notamos que, apesar de o artista contextualizar seus trabalhos com tendências da vanguarda, ele mantinha os aspectos regionais. Tanto em Lenhador como em Ceifeiro o artista retrata o homem comum, o trabalhador do campo, como um herói.

Figura 22 - K. Maliévitch: Lenhador - 1912-1913

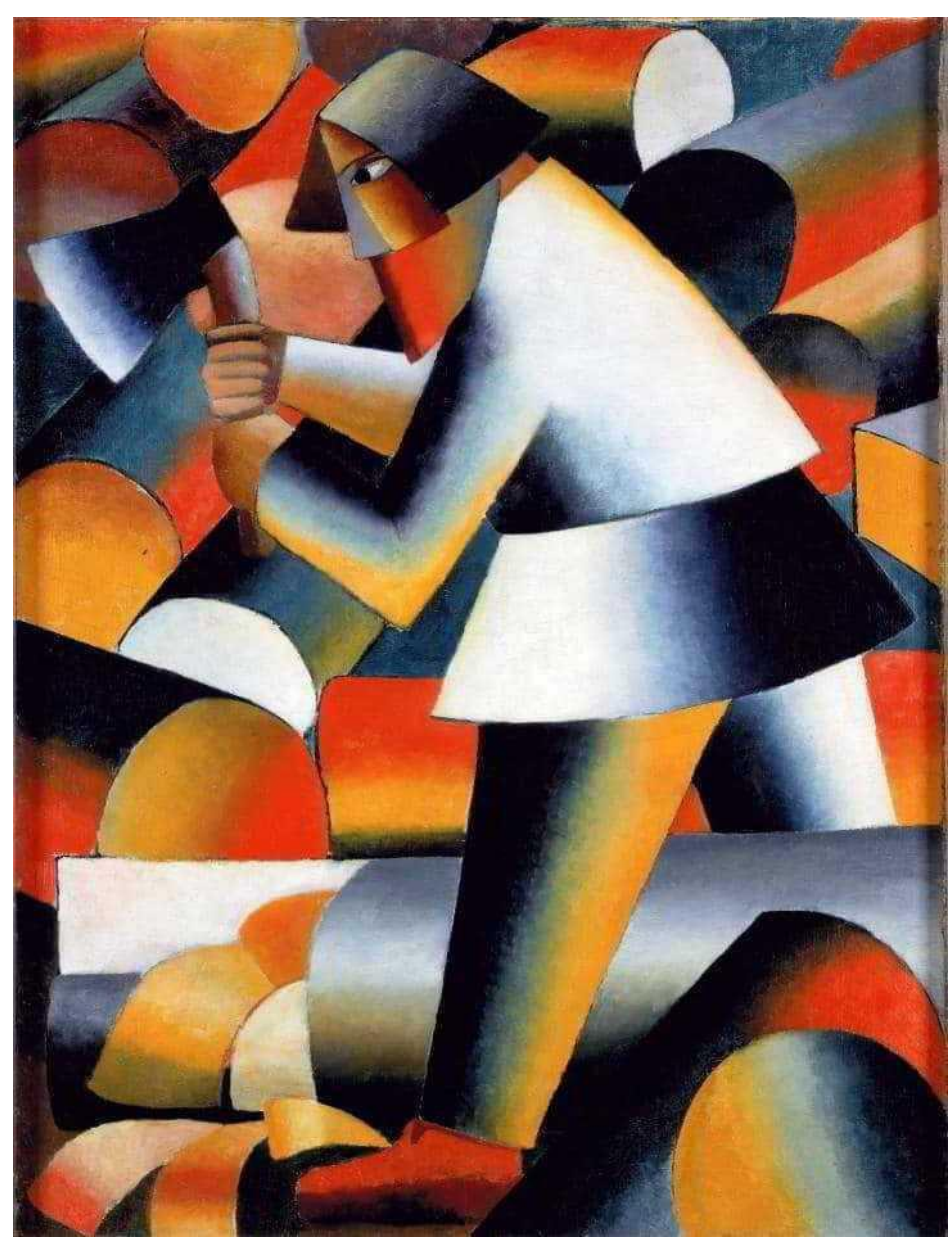

Fonte: Simmen e Kohlhoff (2001). Óleo sobre tela. 94x71,5cm. Stedelijk Museum, Amsterdã. 
Figura 23 - K. Maliévitch: Ceifeiro sobre fundo vermelho - 19

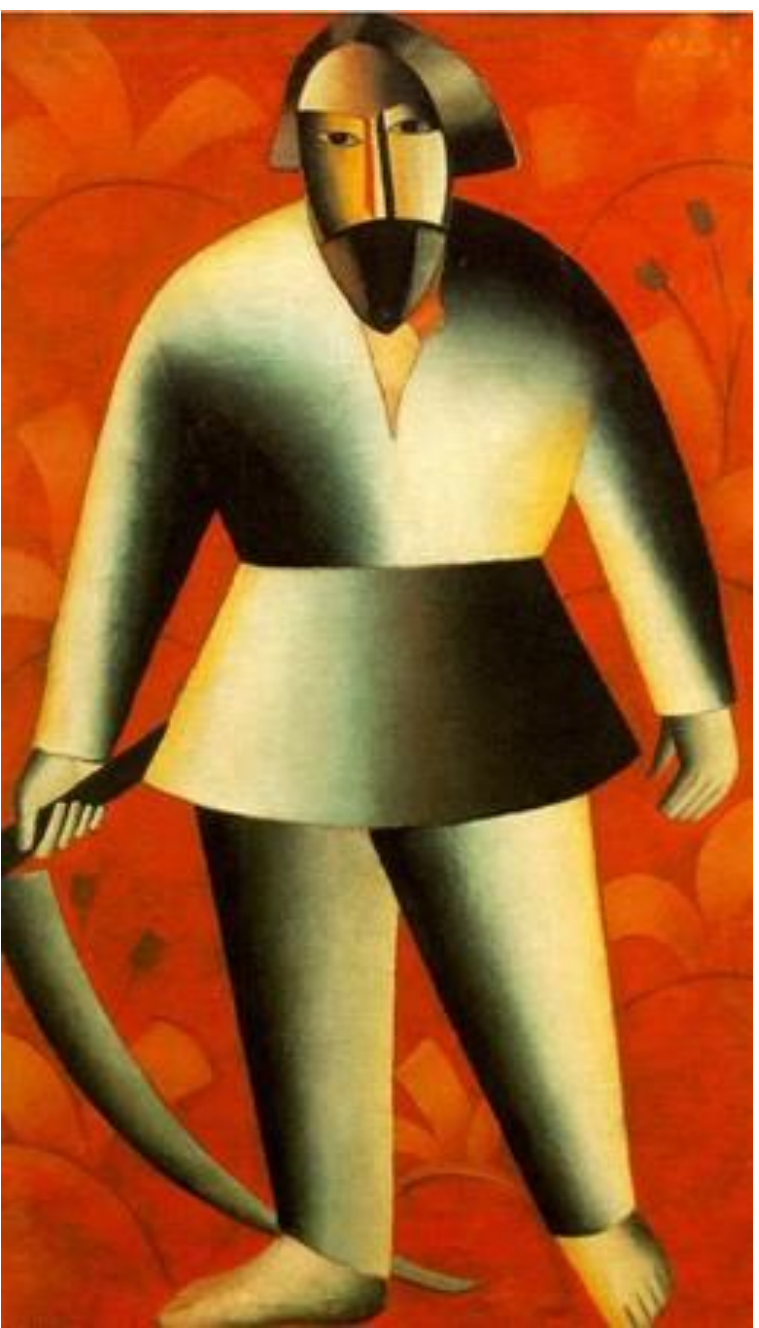

Fonte: Bermejo (1995). 
Figura 24-F. Léger: A mulher de azul - 1912

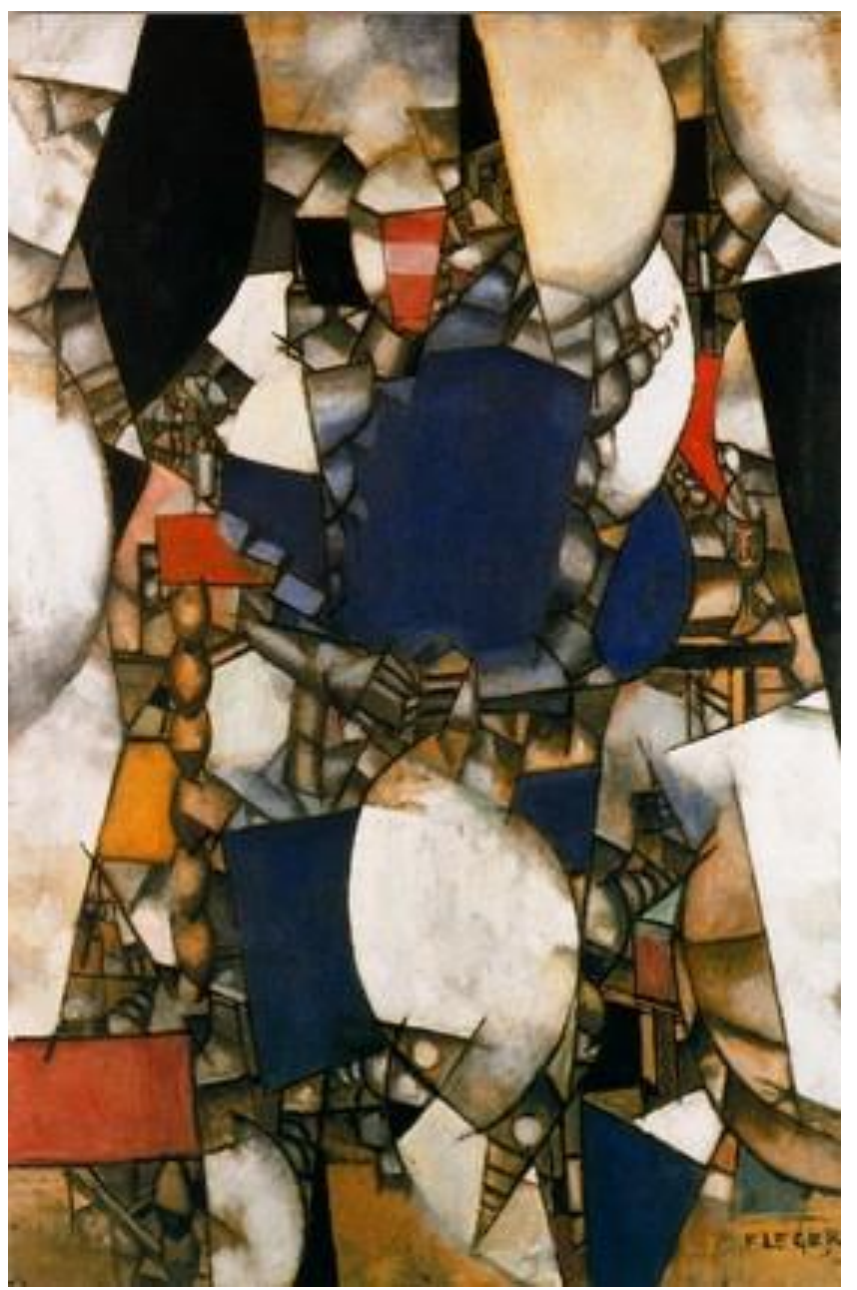

Fonte: disponível em: <www.wikiart.org/en/fernand-leger/contrast-of-form-1913>. Acesso em: 23 jan. 2019.

No mesmo ano, em 1912, Maliévitch não só decompõe o espaço, como os cubistas, mas também deixa as figuras mais planas e reduz os volumes a superfície, e o dégradé, antes utilizado para abaloar a imagem, continua sendo utilizado, mas de modo a planificar o objeto. Na obra Amolador. Princípio de Animação (Figura 25), nota-se o fundo também em movimento, dinamizado, como uma sucessão de imagens num filme. Notam-se também fortes influências da obra $\mathrm{Nu}$ descendant un escalier $n^{\circ}$ 2, de Marcel Duchamp (Figura 26), em que o movimento é obtido pelas repetições consecutivas da imagem. 
Figura 25 - K. Maliévitch: Amolador. Princípio de Animação - 1913

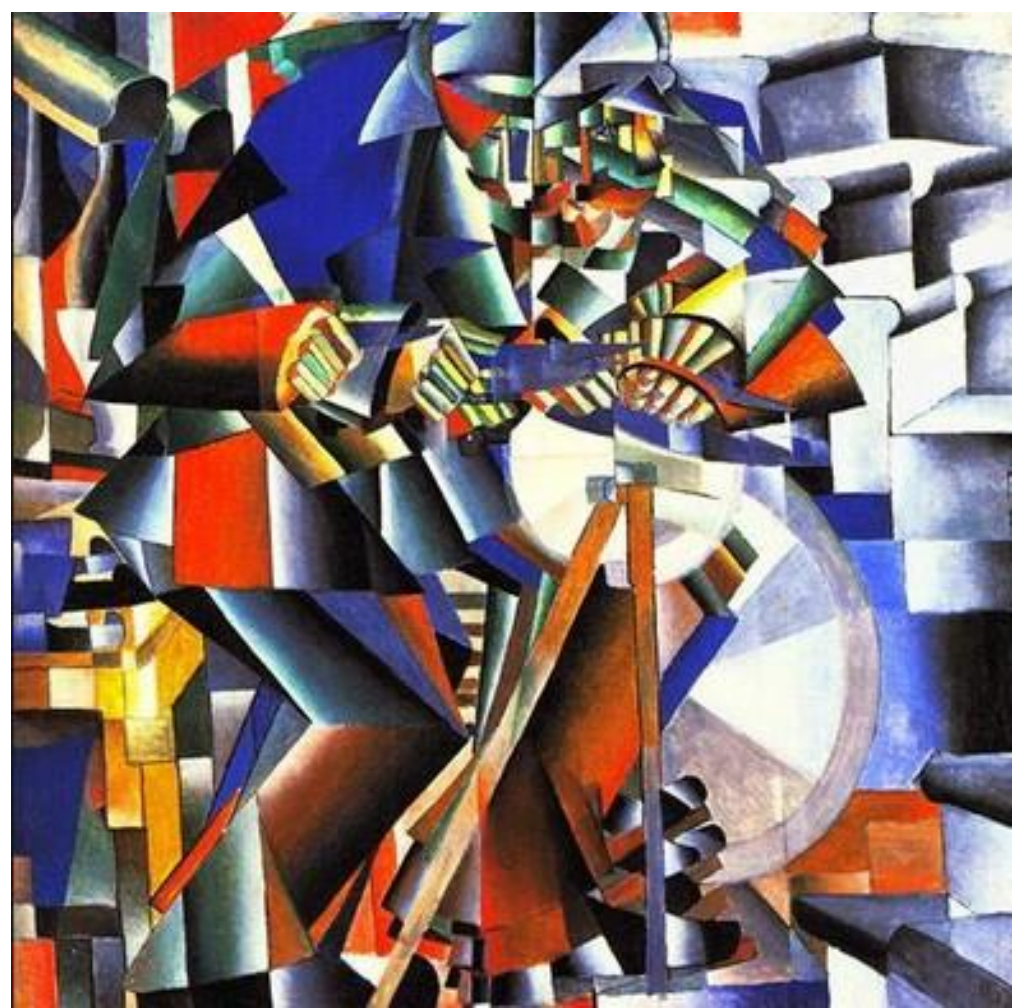

Fonte: Simmen e Kohlhoff (2001). Óleo sobre tela. 79,5x79,5cm. Yale University Art Gallery, New Have.

Figura 26 - M. Duchamp: Nu descendant un escalier nº 2 - 1912-1916

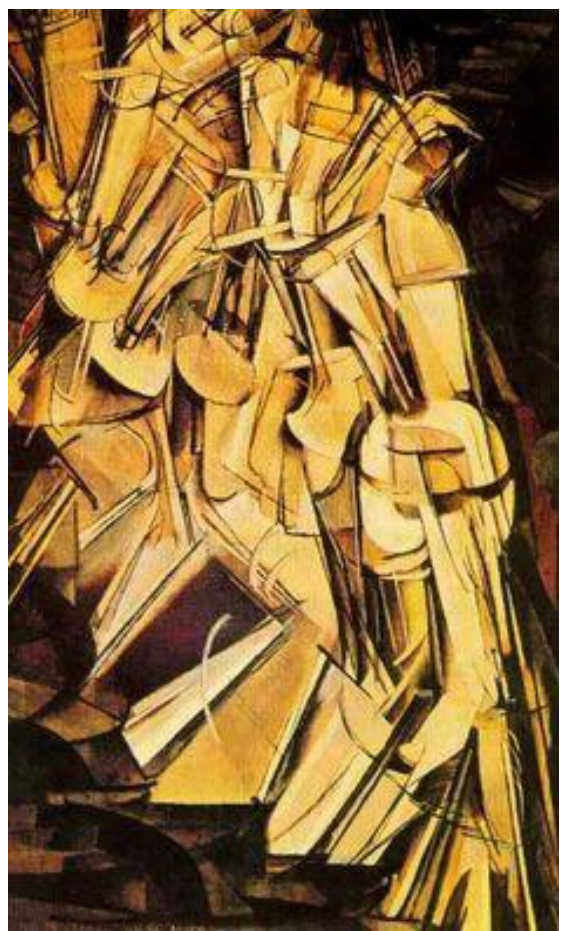

Fonte: Argan (1992). Aquarela, tinta, lápis e pastel sobre papel fotográfico. 1,47x0,89m. Filadélfia, Museum of Art. 
Entre 1913 e 1915, o artista desenvolve uma militância nos grupos futuristas da Rússia pré-revolucionária junto com os poetas Kruchenij e Khlébnikov e com o músico Matiushin. Criam o Zaum, que tinha por objetivo a quebra da lógica racional da representação. Nas criações cubo-futuristas, surgem objetos que estabelecem relações absurdas, destruindo qualquer tentativa de lógica fora da própria pintura. Essa falta de lógica racional, somada a interferências de formas geométricas, preparou o terreno para o resultado pictórico no Suprematismo. Na pintura Retrato Aperfeiçoado de Ivan Kliun (Figura 27), o seu grau de abstração já é maior em relação às obras anteriores. A referência hierática frontal, identificada nos ícones, encontra-se presente na obra.

Figura 27 - K. Maliévitch: Retrato Aperfeiçoado de Ivan Kliun - 1913

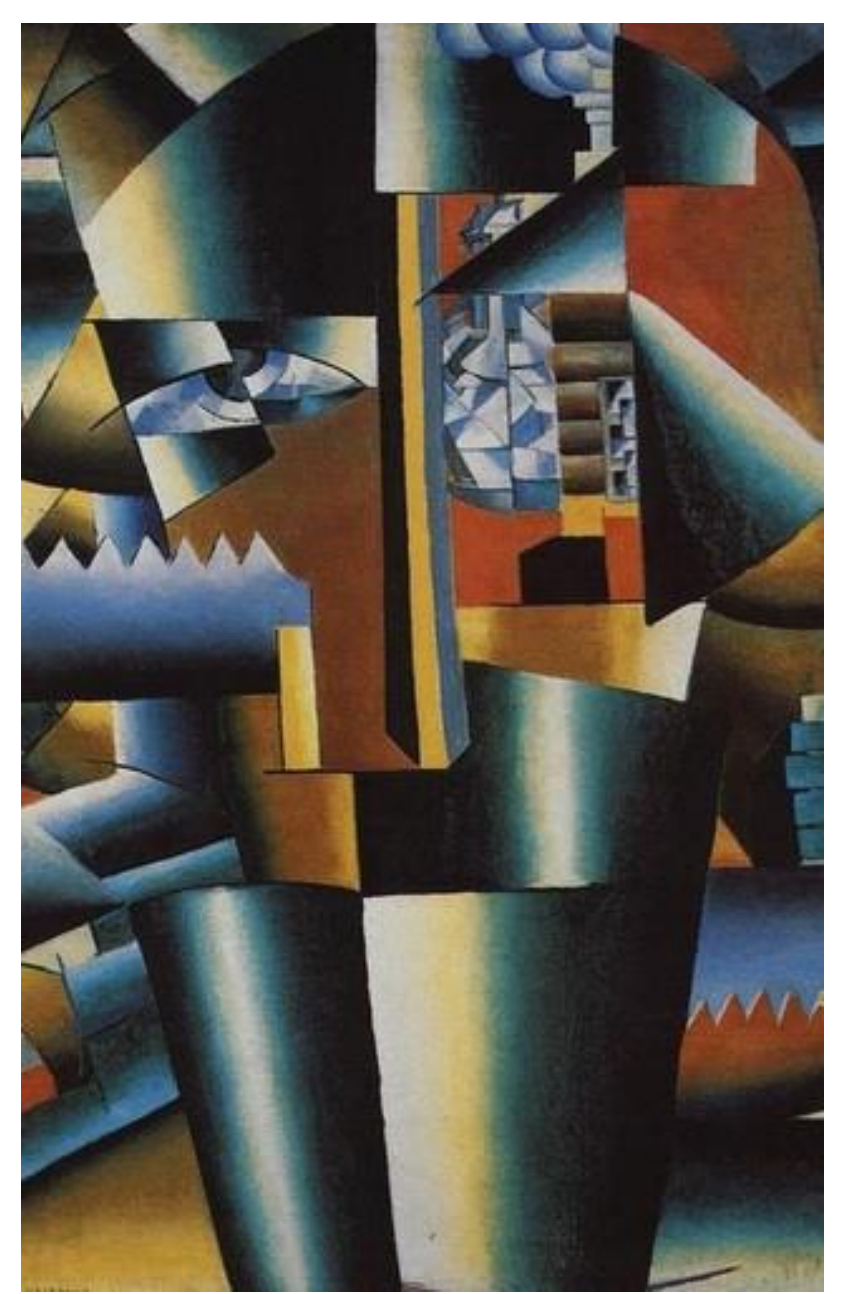

Fonte: Aguilar (2002). Óleo sobre tela. 111,5x70,5cm. Museu do Estado Russo, São Petersburgo.

Na obra Vaca e violino (Figura 28), podemos notar fortes influências cubistas com uma composição quase totalmente plana e um fundo desconstruído utilizando formas geométricas. As curvas são utilizadas com a intenção de proporcionar um leve volume, característica herdada de Picasso, que, empregando o chiaroscuro, construía os volumes em sua fase cubista. 
O predomínio de tons ocres e acinzentados é herdado de Braque, que, diferentemente de Picasso, não construía por volumes e sim por planos, passando a cor a ser mais intelectual do que sensorial. Apesar de Maliévitch construir um fundo cubista, as figuras principais, a vaca e o violino, foram construídas seguindo um modelo mais próximo ao academicismo, não havendo uma total desconstrução de todos os objetos. O suporte de madeira serviu para criar uma espécie de ilusionismo da textura do violino. A ideia de utilizar um animal e um violino é justamente para mostrar a autonomia do quadro, que não precisaria corresponder a uma lógica racional, pois a obra em si já possui sentido próprio.

Figura 28 - K. Maliévitch: Vaca e violino - 1913

Fonte: Bermejo (1995).

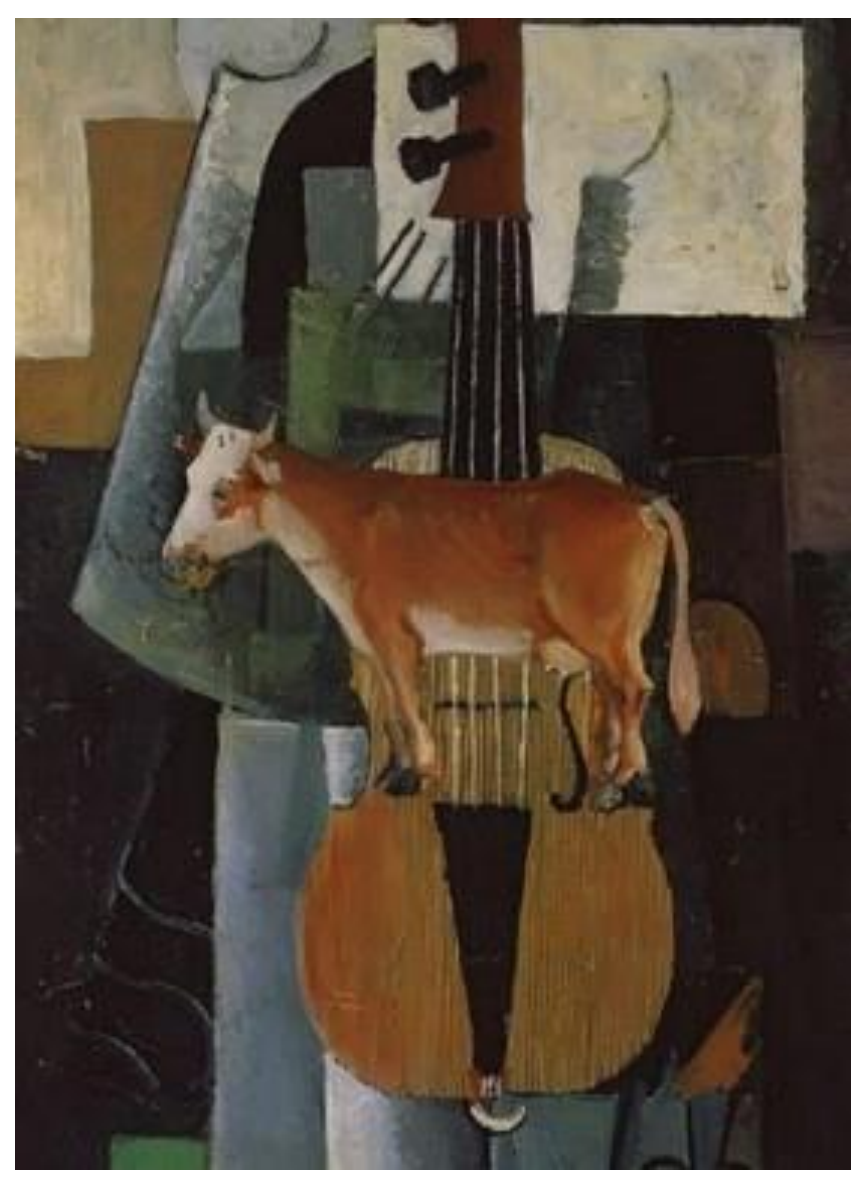

A pintura Um inglês em Moscou (Figura 29) é um retrato sobre Kruchenij. Podemos observar características cubo-futuristas: há um achatamento do fundo e dos volumes com o uso do dégradé. Há também objetos que possuem relação com o personagem, além da utilização de letras na composição. Segundo Argan (1992, p. 430), “[...] são como as letras alfabéticas, signos que, em si, nada significam, mas que são combinados de várias maneiras para significar alguma 
coisa". Isso ocorre por meio do emprego da sobreposição de imagens que fogem de uma lógica racional, seguindo características do Zaum e também do dada ${ }^{10}$.

Figura 29 - K. Maliévitch: Um inglês em Moscou - 1914

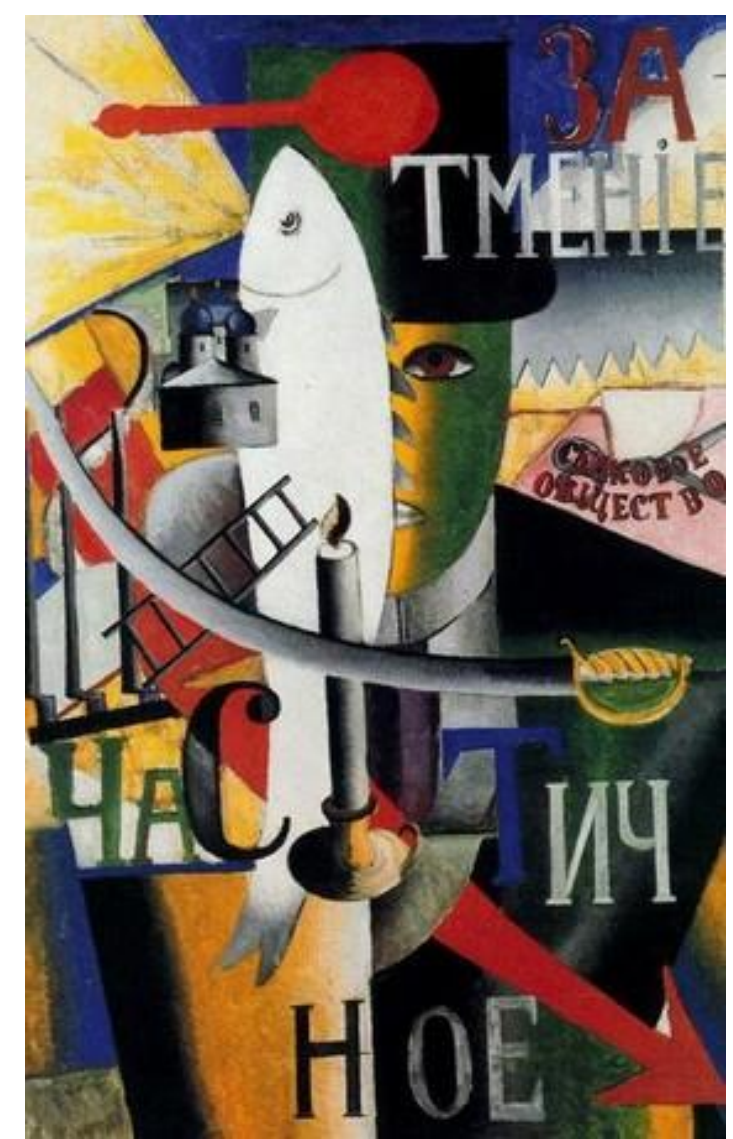

Fonte: Simmen e Kohlhoff (2001). Oleo sobre tela. 88x57cm. Stedelijk Museum, Amsterdã.

\subsection{O visível e o invisível em Maliévitch}

No início do século XX, assuntos e ideias neoplatônicas, como a existência de um outro mundo, perfeito e superior, entraram fortemente no circuito artístico. Crenças relacionadas à espiritualidade e à metafísica, como a existência de outras dimensões, foram defendidas por espiritualistas, místicos e pesquisadores que influenciaram muitos artistas da época, entre eles Maliévitch. Nessa época, apesar de trabalharem com poéticas visuais diferenciadas, os artistas da vanguarda carregavam um pensamento em comum: a rejeição pela representação do realismo e do naturalismo na arte, no caso, na pintura.

${ }^{10} \mathrm{O}$ dada foi um fenômeno internacional. Jovens artistas se reuniam para expressar sua indignação pelos conflitos de guerra, comprovando a falência e a hipocrisia dos valores estabelecidos. Eram contra as instituições políticas e sociais, e também contra a arte que atendia aos valores burgueses. Acreditavam que a única esperança era destruir os sistemas baseados na razão e na lógica, substituindo por valores associados à anarquia, ao primitivismo e ao irracional. O termo dada foi criado em Zurique em 1916 (DEMPSEY, 2008). 
O Movimento Simbolista, anunciado pelo poeta Jean Moréas (1856-1910), era contra a falsa sensibilidade e a descrição objetiva, com presença marcante na poesia e na literatura. Os simbolistas buscavam por novas formas de expressão, rejeitando a representação do mundo concreto, e valorizavam a subjetividade na representação artística. Ainda analisando os ideais simbolistas, podemos notar pensamentos primordiais que deram início a um tipo diferente da forma de pensar, como a valorização dos sentimentos e das sensações, a busca por uma arte que fosse o resultado da pureza interior, sem a necessidade de uma representação naturalista. Stéphane Mallarmé foi um dos principais expoentes do movimento, um poeta que desenvolveu ideologias que serviram de embasamento para os pintores simbolistas. Os pensamentos e atitudes de um cidadão comum, de classe média, eram condenados pelos respectivos artistas. Inspirados pelo romântico Charles Baudelaire, os simbolistas acreditavam existir maior realidade na imaginação e na fantasia do que na própria realidade. Esses escritores toleravam a vida em virtude de seus próprios sentimentos e buscavam por uma interiorização íntima, tendo como consequência a rejeição ao mundo exterior, composto por signos e imagens. A teoria das "Correspondências", de Baudelaire, exerceu forte influência nos poetas e pintores. Uma obra de arte deveria ser expressiva nos sentimentos a ponto de se elevar aonde todas as artes estivessem interligadas, sons que sugerissem cores e vice-versa.

[...] pintores e poetas estiveram sempre ligados, tanto em sua associação pessoal como em sua luta por problemas artísticos comuns. Este tipo de associação já tinha sido proposto por Richard Wagner, em seu conceito da "arte total" (CHIPP, 1999, p. 47).

Até o momento, a abstração era obtida como consequência de uma ideia concreta alterada. O poeta Gustave Kahn propõe o inverso, ou seja, que a criação deveria começar pela subjetividade e depois seguir para a objetividade.

Com relação a isso:

Enquanto Baudelaire louvava Delacroix porque suas formas e cores expressavam tão bem o estado de espírito do motivo de seus quadros, Kahn via as qualidades subjetivas, expressivas, das cores e formas como equivalentes, ou mesmo superiores ao motivo representado (CHIPP, 1999, p. 47).

Segundo Bóris Schnaiderman, o simbolismo russo teve como ponto de partida o simbolismo francês, mas desenvolveu características diferentes com elementos próprios e teve muita relação com Dostoievsky. Podemos defender que um dos principais embriões do abstracionismo fora plantado aqui, nas teorias e ideologias dos simbolistas. Artistas da vanguarda Russa, entre eles Kandinsky e Maliévitch, levaram a abstração para um "grau maior de elevação", pelo fato de a proposta pictórica não ser resultado de uma base figurativa. 
Segundo Aurier, há duas tendências contraditórias na história da arte. Uma depende da cegueira, a tendência realista, que seria a representação da aparência material, sem radicalismos. Ele também diz que há características na obra da alma de quem a fez, além de admitir que há obras-primas realistas fascinantes. A outra tendência é ideísta, oposta à anterior, considerada muito mais elevada, pois a arte seria a manifestação representativa do que há de mais elevado, ou seja, a Ideia (AURIER, 1891 apud CHIPP, 1999, p. 85).

Aos olhos do artista [...] os objetos, isto é, os seres relativos que não passam de uma tradução proporcionada à relatividade de nosso intelecto dos seres absolutos e essenciais, das Ideias, os objetos não podem ter valor enquanto objetos. Surgem apenas como signos. São letras de um imenso alfabeto que só o homem de gênio sabe soletra(CHIPP, 1999, p. 86).

Maliévitch, Kandinsky e Mondrian acreditavam que o artista tinha uma sensibilidade exacerbada e eram mediadores entre os mundos físico e espiritual, carregando uma missão de quase profetas. Essa visão mística foi defendida por pesquisadores, entre eles Helena Petrovna Blavatsky (1831-1891), conhecida como Madame Blavatsky ou HPB, e Piotr Demianovitch Ouspensky (1878-1947). Madame Blavatsky é considerada a mãe da espiritualidade moderna. Suas contribuições para a formação do pensamento espiritual são vistas como as mais importantes de sua época à cultura moderna geral. Em seus estudos, predominavam temas sobre sabedoria antiga, conhecimento interior e ensinamentos secretos, uma proposta ao renascimento espiritual, que oferecia um modo de contato como cosmos completamente diferente das religiões tradicionais. Blavatsky fundou, com colegas, uma Sociedade Teosófica em Nova Iorque (1875) que tinha como lema "não há religião superior à verdade". Segundo Lachman, quando Blavatsky morreu, em 1891, o movimento teosófico tinha se difundido em Nova Iorque, Índia e Europa e tinha diversos seguidores, como o inventor americano Thomas Edison e o ativista indiano Mohandas Gandhi.

O jornalista e pesquisador Ouspensky defendia a ideia do eterno retorno. Ele acreditava que, além de uma película fina que representava uma falsa realidade, existiria outra realidade que o homem comum ainda não teria condições de acessar. Nesse momento, em 1914, a Europa já estava no período de guerra, e, analisando as condições da existência humana na busca por novas respostas, Ouspensky não se conformava em ter uma vida que não levasse a parte alguma, por isso a busca por explicações em "universos paralelos". Acreditava que conseguiria acessar novas informações sobre a vida e o cosmos vindas das filosofias orientais. No início da busca de novos conhecimentos, o pesquisador chegou até a imaginar a possibilidade de estabelecer contato com escolas do passado remoto, como a escola de Pitágoras, mas, sempre atento à sedução do tema, notou que, mesmo em se tratando de um assunto metafísico, teria que ter uma ordem de 
pensamento, o que o levou a procurar uma escola que não fizesse apelos a regras relacionadas a religiosidade nem a algum tom devocional.

Sobre isso: "[...] a ideia de uma verdade espiritual servia a alguns como uma luz pela qual eles viam revelado o que tomavam pelos valores genericamente materialistas do mundo contemporâneo" (HARRISON; FRASCINA; PERRY, 1998, p. 210).

Apesar de o Manifesto Suprematista não ter relação com qualquer religião, são claras as influências do pensamento espiritual "moderno". Quando Maliévitch propõe um mundo sem objetos, um reinício, uma viagem ao âmago das sensações, apresenta ideias intimamente relacionadas aos pensamentos espiritualistas moderno e metafísico propostos principalmente por Madame Blavatsky e por Ouspensky.

A iconografia, desde o século XIII, sempre esteve presente na vida dos russos devido ao predomínio da Ortodoxia. Construtores e pintores de ícones vieram de Bizâncio, e o povo de "RUS" - nesta época a atual Rússia era conhecida por RUS de Kiev - começou a aprender com a sua arte. A forte religiosidade do povo foi fator decisivo para a evolução da arte dos ícones, que desde sempre estiveram ligados à religião na Rússia. O cristianismo ortodoxo determinou o caráter da cultura russa até o século XVIII e a partir do século XX continuaria a influenciá-la, porém de outra forma. Os ícones russos também tiveram presença constante na obra de Maliévitch. A presença da iconografia acompanhou o artista desde sua infância. A iconóstase foi ponto de encontro do mundo espiritual com o mundo material. Essa conexão de dois "mundos" é um dos fatores principais para a construção do pensamento suprematista. Na era dos ícones, se houvesse uma arte pictórica diferente, não subsistiria, pois todos os meios artísticos concentravam-se na arte eclesiástica. A maioria da população russa morava em principados e aldeias, e, devido à imensidão do país, as novas tendências que chegavam a São Petersburgo e Moscou demoravam para chegar aos povoados e, quando chegavam, ainda encontravam resistência.

Nos séculos XIV e XV, houve uma florescência de pinturas icônicas em Moscou, e, devido a questões políticas, a igreja renovava seu poder. Há um renascimento religioso e uma fé fervorosa destinada a São Sérgio ${ }^{11}$. Os ideais do sacerdote influenciaram não só a iconografia, mas também os monastérios e a sociedade civil, pensamentos e ensinamentos que permaneceram até a revolução bolchevique de 1917.

\footnotetext{
${ }^{11}$ Ordenado sacerdote para o melhor exercício da vocação de formar os monges na fundamental regra da oração e do trabalho, viveu São Sérgio: os "filhos", a pobreza, a mansidão e total confiança na Divina Providência. São Sérgio escreveu tanto que é considerado o grande educador nacional do povo russo. Faleceu com quase 80 anos de idade, em 25 de setembro de 1392, no mosteiro da Santíssima Trindade.
} 
As características dos ícones russos, herdados da arte Bizantina, possuem peculiaridades diferentes das dos ícones de Bizâncio. Enquanto os ícones russos apresentam mais fatos da vida (Figura 30) e possuem mais movimentos, os de Bizâncio são mais solenes, hieráticos e mais estáticos (Figura 31) (AGUILAR, 2002, p. 18). Além disso, os ícones seguem os modelos arquetípicos prescritos pelos manuais de iconografia. Podemos comprovar essas diferenças na comparação de obras de três ilustres artistas: Teófanes, o grego - fim do século XIV (Figura 32) -, Andrei Rubliov - início do século XV (Figura 33) - e Mestre Dionísio - entre os séculos XV e XVI (Figura 34).

\section{Figura 30 - Mãe de Deus do Enternecimento de Vladímir}

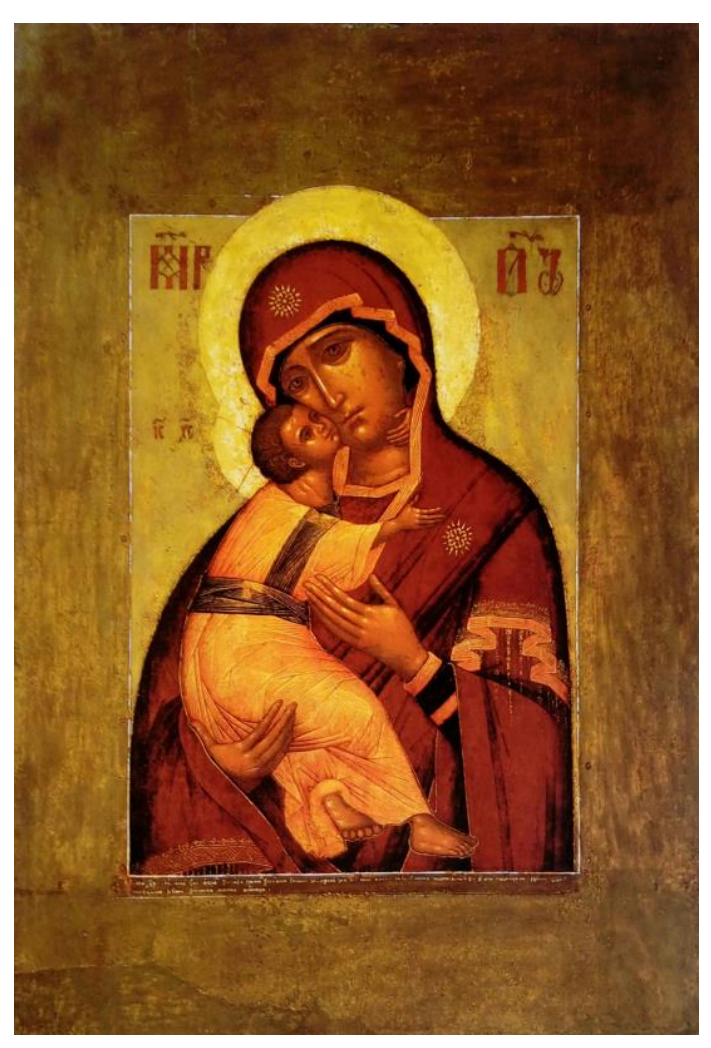

Fonte: Aguilar, 2002. 
Figura 31 - Mãe de Deus Odiguítria de Jerusalém

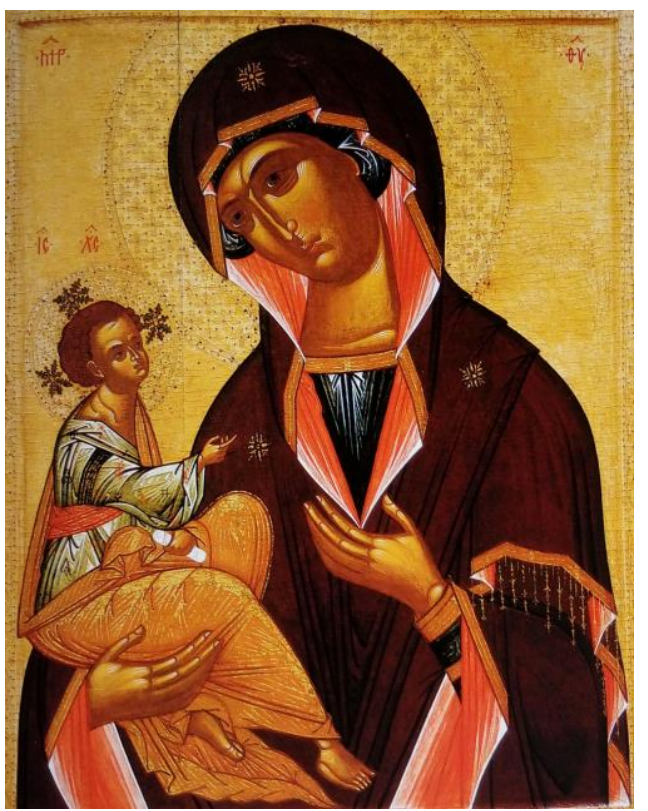

Fonte: Aguilar, 2002.

Figura 32 - Teófanes

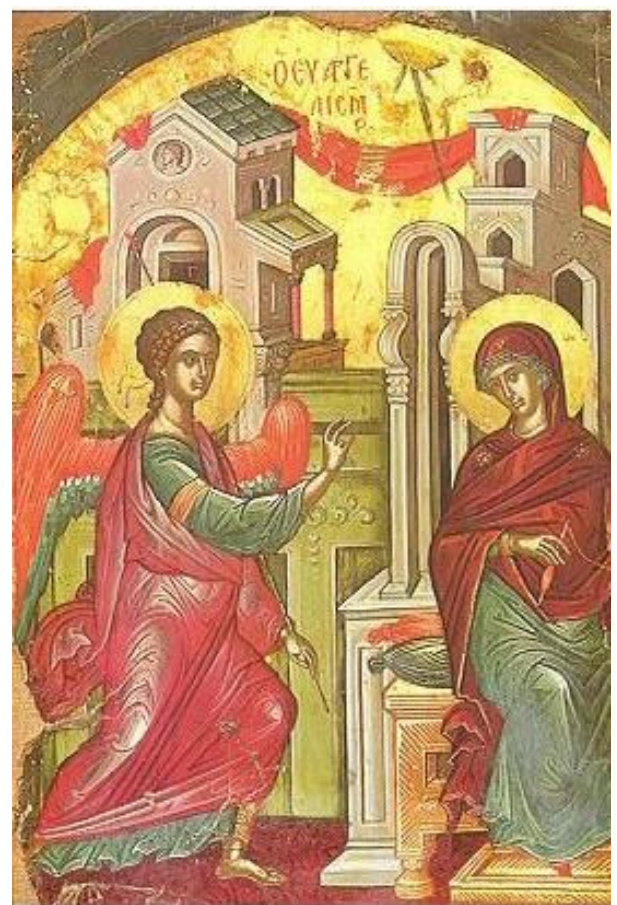

Fonte: disponível em: <www.ecclesia.com.br/biblioteca/iconografia/meditando_anunciacao>. Acesso em: 15 jan. 2019. 


\section{Figura 33 - Rublióv}

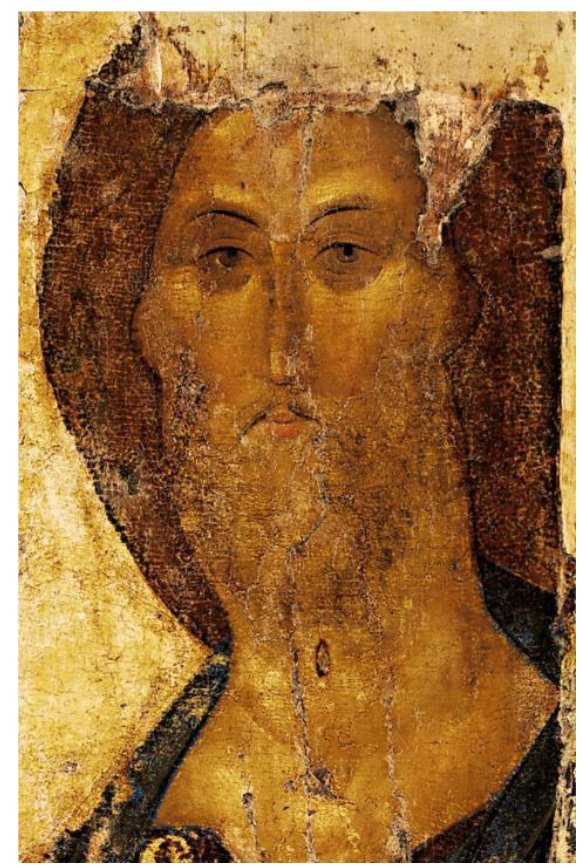

Fonte: disponível em: 〈http://artemazeh.blogspot.com.br/2017/02/andrei-rublev-e-os-icones-russos〉. Acesso em: 15 jan. 2019.

\section{Figura 34 - Dionísio}

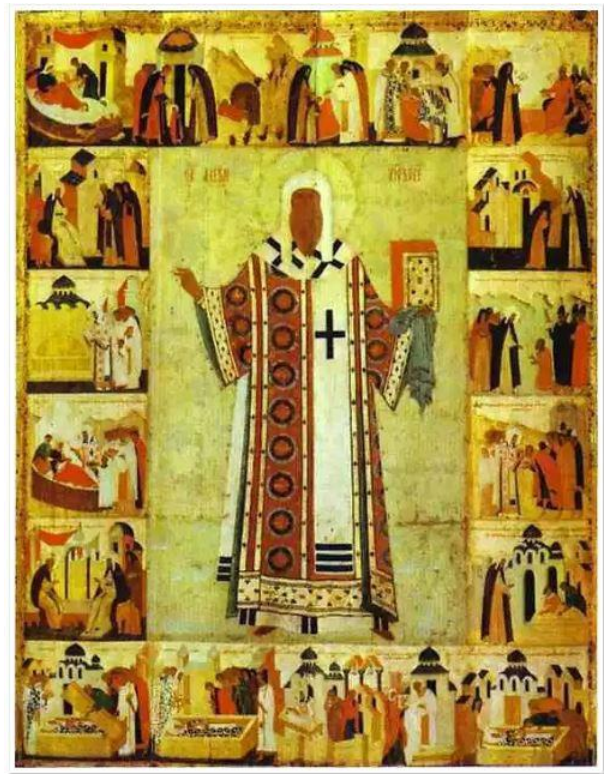

Fonte: disponível em: <artesehumordemulher.wordpress.com/pinturas-de-dionsio>. Acesso em: 15 jan. 2019.

Frequentemente, os ícones mostram partes do corpo que seriam impossíveis de serem vistas ao mesmo tempo. Por exemplo, há um modo específico de fazer a pintura de um rosto. O nariz é sempre voltado ao espectador, e a tinta dourada é utilizada para demonstrar o que não 
se vê (a auréola do Santo, os raios de luz). Essas características, citadas aqui quase como regras, não diminuem o trabalho do artista. A intenção e o talento humano são fundamentais para a criação do espaço físico e etéreo do quadro.

De acordo com Pável Floriênski (1882-1937), matemático, teólogo, físico, historiador da arte e padre ortodoxo, considerado por muitos como o "Leonardo da Vinci russo", não há somente um sistema geométrico que mostra a experiência da realidade. Há também outra perspectiva capaz de atingir uma realidade intangível, baseada na estrutura invisível de uma realidade metafísica e que se encontra presente na pintura dos ícones russos. Esse "sistema" ele denomina de perspectiva inversa ${ }^{12}$. (FLORIÊNSKI, 2012)

O pintor de ícone não utilizava a perspectiva renascentista por opção, não por falta de conhecimento. $\mathrm{O}$ uso da perspectiva inversa foi o modo que o artista encontrou para retratar uma sensibilidade superior.

Sobre o pensamento de Floriênski:

[...] a perspectiva inversa das obras daquele período (Idade Média) não decorria do fato de os pintores russos de ícones desconhecerem as leis da óptica que haviam sido assimiladas pelo Renascimento italiano depois de terem sido elaboradas, na Itália, por Leon Battista Alberti. Floriênski argumenta, de modo convincente, que não era possível observar a natureza sem vir a descobrir a perspectiva, estando esta, portanto, destinada a ser descoberta. Naquele momento, porém, ela podia ser necessária - podia-se ignorá-la. Assim, a perspectiva inversa na antiga pintura russa, a rejeição da pintura renascentista, expressa a necessidade de lançar luz sobre certos problemas espirituais que os pintores russos se colocavam, ao contrário dos artistas do Quattrocento italiano (FLORIÊNSKI, 2012, p. 13).

Poderíamos afirmar que a metafísica é uma constante nas pinturas de ícones, assim como nas obras de Maliévitch. Diferentemente da arte religiosa ocidental, em que cada pintor desenvolvia um tema de acordo com um pedido específico do clero, a pintura de ícone não é considerada uma arte individualista nesse sentido. Mesmo que cada pintor deixe marcadas suas características pessoais em uma pintura, o ícone nasce do consenso de uma comunidade eclesiástica. Os pensadores russos defendem que o ícone por si só representa uma transfiguração terrena de um cosmos.

Com relação à definição do caráter da iconografia russa:

A iconografia é a metafísica da existência concreta. Se a pintura a óleo é mais apta a reproduzir os dados sensoriais do mundo, se a gravura faz o mesmo com seu esquema racional, o ícone faz transparecer a essência metafísica daquilo

\footnotetext{
${ }^{12}$ De acordo com a apresentação de Neide Jallageas no livro A perspectiva inversa, "o autor [Pável Floriênski] não pensa, de forma alguma, em construir uma teoria da perspectiva inversa, tão somente gostaria de sublinhar, com energia suficiente, a existência do pensamento orgânico em um campo concreto". (Floriênski, 2012,pg. 17)
} 
que representa. Se as técnicas pictoriais e gráficas elaboram-se em função de necessidades culturais e se apresentam como condensação de uma época, a técnica iconográfica exprime-se pela exigência de exprimir a metafísica do mundo (AGUILAR, 2002, p. 96).

A percepção da importância do ícone russo retornou na segunda metade do século XIX e se impôs no século XX. A exposição para o Tricentenário de Románov, organizada em Moscou para celebrar o reinado de mil anos da dinastia dos Románov, influenciou no processo criativo da vanguarda russa nas décadas de 1910 e 1920. Os artistas dessa época tiveram consciência do tesouro nacional que havia sido construído por artistas russos no passado.

[...] o ícone como força expressiva, no momento em que são limpos, na exposição para o Tricentenário de Románov, em 1913, mudou completamente a qualidade visual da arte de vanguarda russa, porque se apreciou pela primeira vez um ícone como obra de arte ou mais forte do que obras de arte renascentistas, mais forte que a arte de Michelangelo, quer dizer uma arte realmente com condições expressivas, além da arte que você notou, além da arte bizantina mais hierática, muito cerimonial, enquanto que a arte de Andrei Rubliov é uma arte imediatamente transitiva, capaz de entrar em contato com todos (AGUILAR, 2002, p. 20).

\subsection{O Suprematismo}

De acordo com a Teoria do Elemento Adicional, desenvolvida por Maliévitch, o Cubismo, o Futurismo e o Suprematismo devem ser considerados como um tipo de arte advinda do meio industrial, tenso, pois suas características dependem desse ambiente, assim como a arte de Cézanne depende da província. Um artista urbano, cubista, futurista ou suprematista, se fosse viver no campo, perderia paulatinamente o elemento adicional de sua origem. Em virtude da influência do novo meio, retornaria à imitação da natureza. De acordo com esse raciocínio, não poderia existir Futurismo no campo, já que os futuristas têm a consciência sempre ativa e vivem de acordo com o ritmo acelerado da cidade. Outra percepção do artista é a de que há uma preferência do público por uma arte provinciana e uma rejeição à arte urbana.

Se, após uma estada mais prolongada na província, um futurista ou um cubista retornasse à cidade com uma série de adoráveis paisagens, ele seria alegremente recebido por seus amigos e pelos críticos como alguém que redescobriu a arte sadia. Isto caracteriza não apenas a atitude daquele que mora na província, como também a dos habitantes da grande cidade, pois eles - até eles! - ainda não se integraram à cultura metalizada da cidade grande, à cultura da nova natureza humana (MALIÉVITCH apud CHIPP, 1999, p. 342).

Considerando os fatores citados, a pintura encontra-se numa encruzilhada definida por três campos de força: a arte metálica - cubista e futurista - urbana; a arte de cavalete - plástica -, 
que pertence à província; e a arte utilitária - união da arte com a tecnologia. De acordo com o artista, não há aplicação para a arte.

Em defesa da superioridade da arte urbana:

[...] o elemento diferenciador entre a "multiplicação" da forma produzida pelos futuristas e a dos pintores assim chamados realistas (naturalistas) pode ser reconhecido na medida em que a multiplicação feita pelo futurista é crescente, ao passo que a do realista nunca passa de 1x1=1 (MALIÉVITCH apud CHIPP, 1999, p. 344).

O ano de 1913 foi intenso na vida artística de Maliévitch. Além de apresentar pinturas cubo-futuristas, participou do Primeiro Congresso Futurista de Todas as Rússias. Dessa reunião de vanguarda surgiu uma proposta de uma forma futurista de teatro juntamente com Matiushin e Kruchenykh, a ópera Vitória sobre o Sol. O sol, como símbolo do iluminismo, foi para os autores da ópera um sinônimo da estética ultrapassada. Essa ópera simbolizou a vitória da arte sobre a "estética esgotada".

Com relação a um trecho da ópera Vitória sobre o Sol: “O Sol está pálido [...] Viva a escuridão! E os deuses negros [...] O Sol da idade do ferro morreu [...] Os nossos rostos são escuros [...] A luz está em nós" (SIMMEN; KOHLHOFF, 2001, p. 50).

$\mathrm{O}$ projeto da ópera era absurdamente moderno, no sentido de ser antinaturalista. A linguagem alógica de Kruchenykh alia-se à música de Matiushin, constituída por gemidos e gritos, característicos da proposta Zaum. Os figurinos e o cenário foram criados por Maliévitch. Nos desenhos, o artista utilizou uma linguagem cubo-futurista que seguia suas pinturas da época. A maioria dos personagens utilizava máscaras. O corpo também era coberto de modo que as formas corporais desaparecessem quase por completo. Os materiais utilizados nas roupas, como papelão e arames, dificultavam de propósito os movimentos dos atores para que se locomovessem de modo pesado. Os personagens são anônimos, como o Desportista, o Novo, o Muitos, o Malvado. Maliévitch utilizou preto e branco, além de cores primárias. A escala cromática das roupas não harmoniza com a anatomia humana. $\mathrm{O}$ artista realçava algumas partes do corpo com o uso das cores. Definiu um tipo de bailado multicolorido e inaugurou uma nova lógica visual e abstrata do espaço (Figuras 35, 36, 37, 38 e 39). Os telões de fundo do cenário eram desprovidos de ilusão de profundidade, novamente de acordo com a estética cubista. No quinto quadro (Figura 40), Maliévitch reduziu o espaço cênico de modo que o fundo limitava-se a um retângulo dividido na diagonal. 
Figura 35 - K. Maliévitch: Representação da Vitória sobre o Sol - 1913

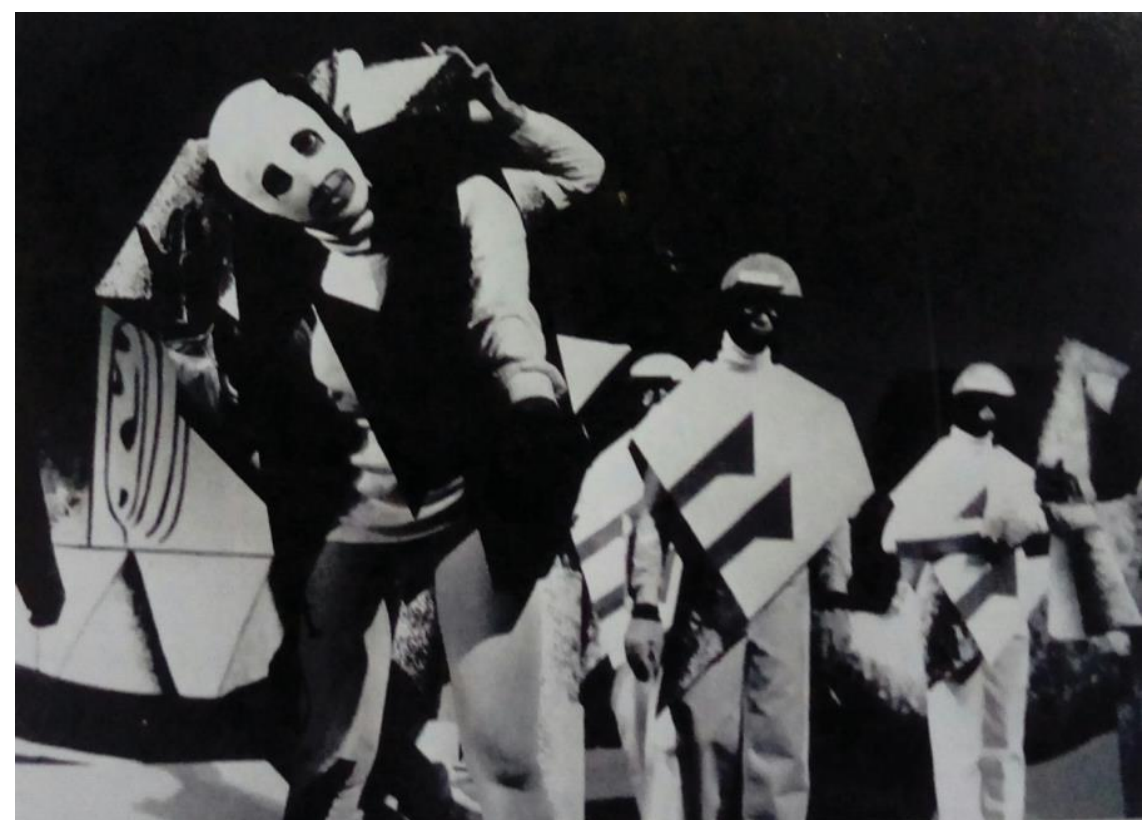

Fonte: Simmen e Kohlhoff (2001).

Figura 36 - K. Maliévitch: Homem Forte - 1913

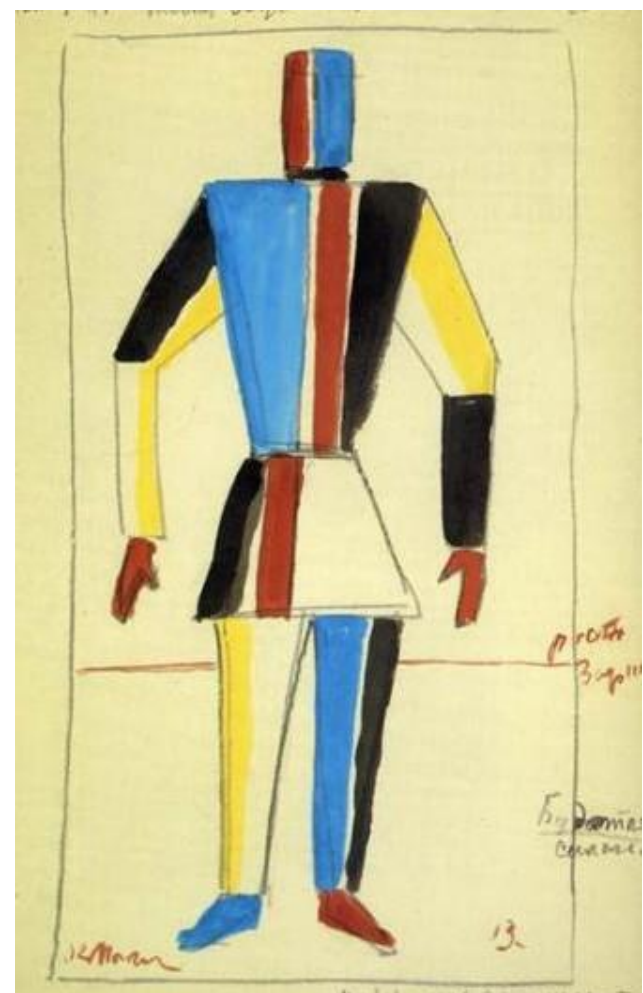

Fonte: Simmen e Kohlhoff (2001). Aquarela, carvão sobre papel. 53,3×36,1 cm. Museu do Estado Russo, São Petersburgo. 
Figura 37 - K. Maliévitch: O Novo - 1913

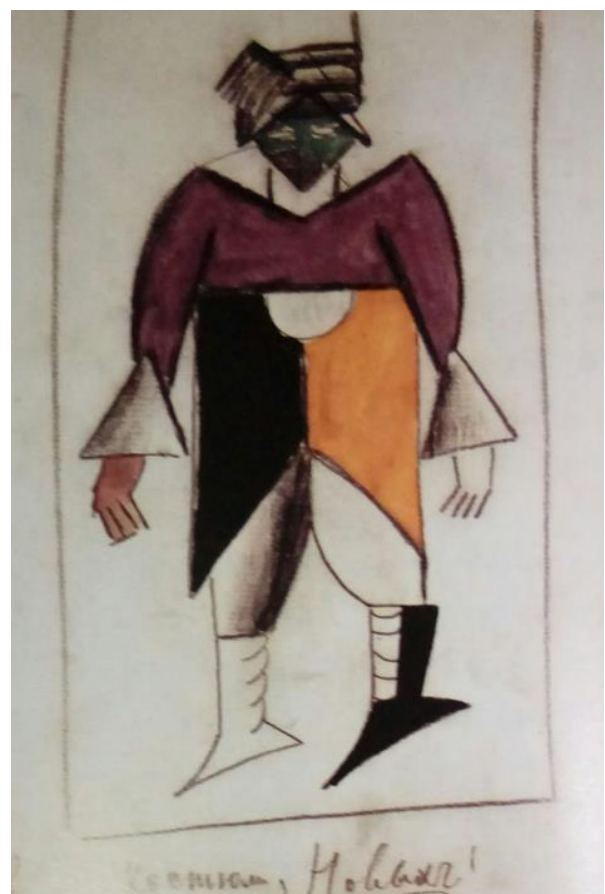

Fonte: Simmen e Kohlhoff (2001). Giz preto, aquarela e tinta-da-china. 26x21 cm. Museu Nacional da Música e do Teatro, São Petersburgo.

Figura 38 - K. Maliévitch: Esportista - 1913

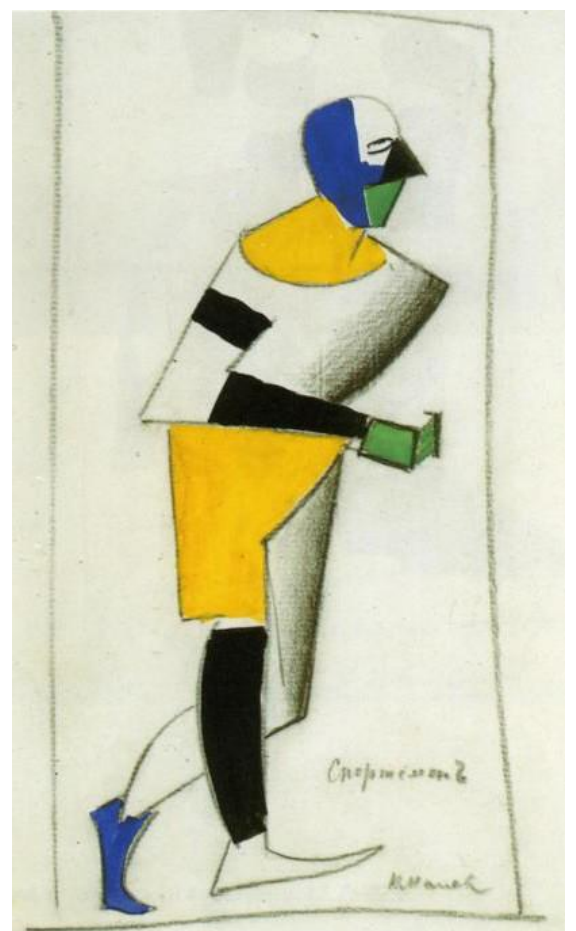

Fonte: Harrison, Frascina e Perry (1998). Aquarela, nanquim e carvão sobre papel. 27x21cm. Museu Estatal Russo, São Petersburgo. 
Figura 39 - K. Maliévitch: Figurinos - 1913

Fonte: Gray (2004).

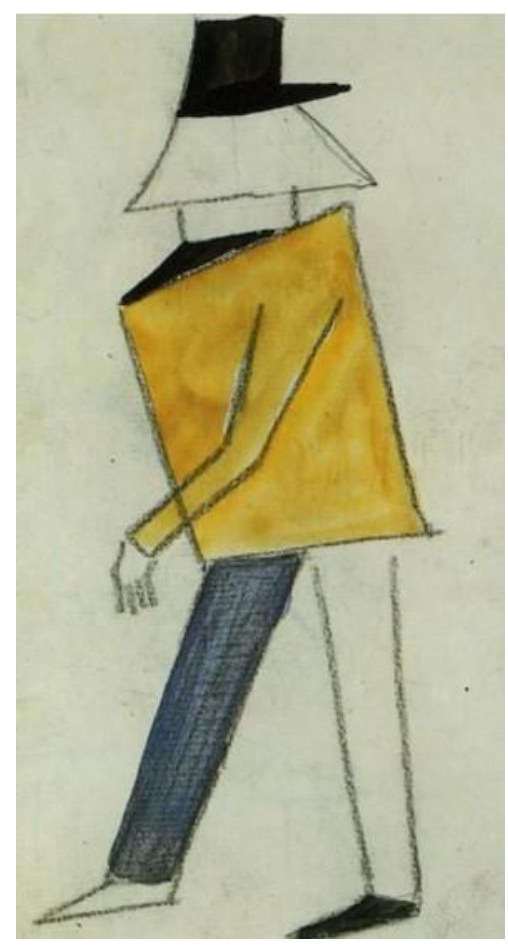

Figura 40 - K. Maliévitch: Quadrado negro - 1913 (estudo cenográfico da ópera Vitória sobre o Sol)

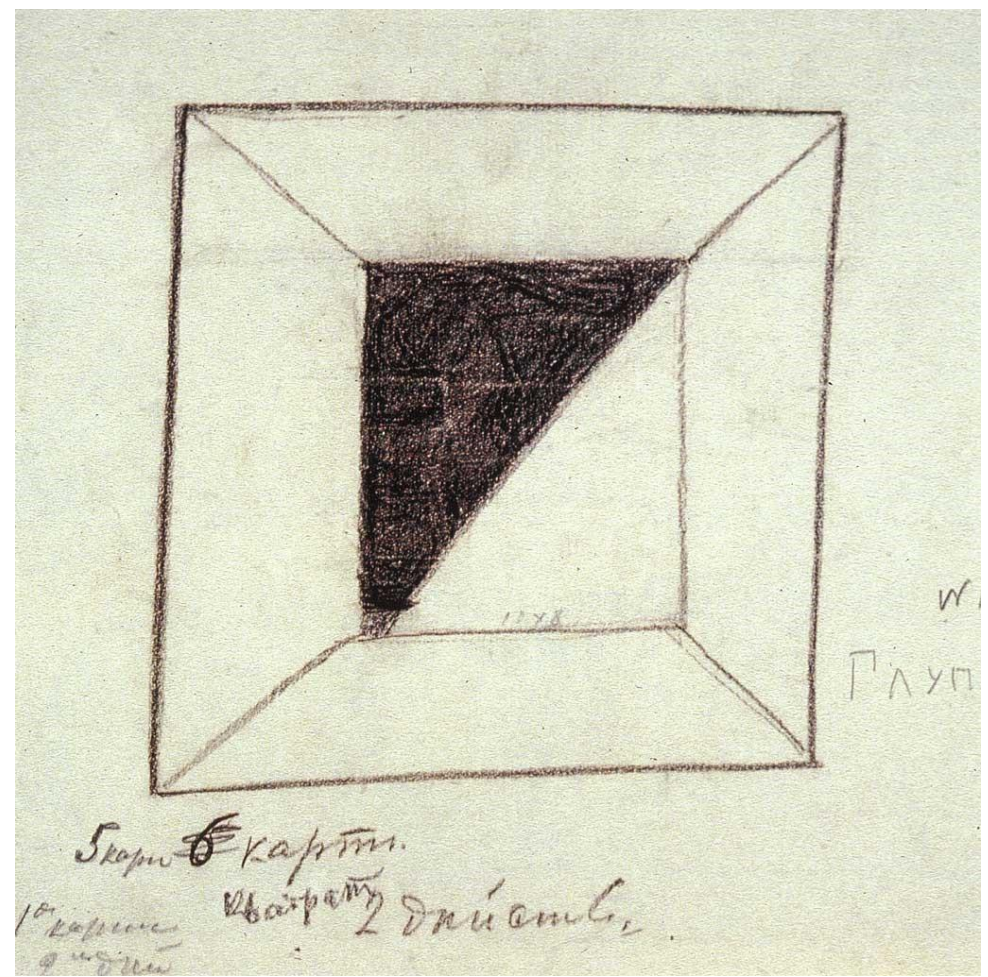

Fonte: Simmen e Kohlhoff (2001). Carvão sobre papel. 21x27cm. Museu Nacional da Música e do teatro. São Petersburgo. 
Podemos observar, nas pinturas que aderiram ao Zaum, que o artista utilizou para a representação pictórica desta estética características do cubo-futurismo, em se tratando da composição de imagens e tratamento das cores, mas, por trás de todos esses conceitos, houve imagens constituídas por vários signos conhecidos, aliados e compostos de modo alógico. A base de todos esses processos foi construída por imagens figurativas e conhecidas, que foram submetidas a estilos de composição que não seguiram uma lógica racional na composição da obra.

Estudando o movimento pictórico cubista, julguei que a cultura pictórica deve seguir sem objeto [...] devemos construir uma nova forma pictórica sem imitar as formas prontas, e, consequentemente, já nos direcionaremos para o caminho espontâneo da criação [...] (SIMMEN; KOHLHOFF, 2001, p. 51).

A partir da ópera Vitória sobre o Sol, podemos notar que o trabalho de Maliévitch deu um imenso salto a caminho da criação da estética pictórica e conceitual do Suprematismo. $\mathrm{O}$ artista trabalhou os figurinos de modo cubo-futurista, como já vimos, e, mesmo tendo uma base real e figurativa, no caso o corpo humano, ele se supera na criação do fundo do palco, onde o Quadrado Preto (Figura 37) aparece pela primeira vez.

Segue um trecho da carta do artista enviada a Matiushin: "A cortina representa um quadrado preto, o embrião de todas as possibilidades, que, ao desenvolver-se, chega a atingir uma força tremenda [...] É o início da vitória" (SIMMEN; KOHLHOFF, 2001, p. 35).

Maliévitch acredita na verdadeira revolução de que a arte possa transformar vidas e, partindo desse princípio, propõe pictoricamente um abstracionismo radical.

Sobre esse aspecto:

A verdadeira revolução não é uma substituição de uma concepção de mundo decadente por uma nova concepção: é um mundo destituído de objetos, noções passado e futuro, uma transformação radical em que o objeto e o sujeito são igualmente reduzidos ao "grau zero" (ARGAN, 1992, p. 324).

Maliévitch assume que chegou inconscientemente à ideia do quadrado preto. Esse processo é comum na história da arte. O resultado inconsciente de um trabalho equivale a uma resposta de um conjunto de questões carregadas anteriormente pelo artista. Numa carta enviada a Matiushin em 1915, o artista escreveu:

Ficarei muito grato se você mesmo posicionar meu desenho de cortina para o ato no qual a vitória é ganha [...] Esse desenho [ou projeto] terá grande significação para a pintura: o que foi feito inconscientemente está agora dando frutos extraordinários (HARRISON; FRASCINA; PERRY, 1998, p. 236).

No texto From Cubism and Futurism to Suprematism, Maliévitch (1915) descreve o Suprematismo como o último estágio de um desenvolvimento progressivo, fazendo uma analogia com a "arte dos selvagens". Seguindo este pensamento, o homem selvagem iniciou um tipo de 
representação visual com a tentativa de produzir uma autoimagem e também imagens miméticas da natureza, resultando no naturalismo, que alcançou o auge da representação no Renascimento. Sendo assim, o Quadrado Preto poderia ser o início de uma nova derivação estética, retornando às formas puras, um ponto de origem que partiria do zero da forma, um reinício sem interferências do passado. Esse novo estilo na pintura, chamado de "novo realismo pictórico" ou "suprematismo", defende o movimento do ato criativo, a transformação do mundo visível. O homem sempre deve inventar o novo e, sendo assim, não se pode afirmar que um tipo de beleza seja eterna. Assim como na natureza, sempre estamos em desenvolvimento e, por fazermos parte dela, não há como caminhar ao passado na arte.

Sobre essa questão:

Agora que a arte, graças ao Suprematismo, encontrou-se a si mesma, encontrou sua pura e inaplicada forma e reconheceu a infalibilidade do sentimento nãoobjetivo, ela tenta estabelecer uma nova e verdadeira ordenação do mundo, uma nova visão de mundo (MALIÉVITCH apud CHIPP, 1999, p. 350).

Entre outras considerações do movimento, foi declarado que a economia era uma nova dimensão, a quinta. $\mathrm{O}$ ato econômico, para Maliévitch, seria o acesso à quinta dimensão, o contato com um plano mais elevado, a intuição, e também um modo de gastar menos energia associada à mimesis, que hoje não faz mais sentido. Essa nova forma de pensar traz novas definições para a contemporaneidade da criação e da arte, consequentemente, o novo realismo pictórico. Não somente o Suprematismo, mas também o Cubismo e o Futurismo estão baseados nesse tipo de ato. De acordo com o artista, se a arte continuar seguindo o velho ato estético, não participará do mundo atual, pois, quando surgiu o naturalismo na arte, os gregos e os romanos alcançaram excelência em sua pesquisa, mas o mundo e a arte caminham incansavelmente e muito se conhecerá depois de nós.

[...] a arte de Rafael, Rubens, Rembrandt, e outros, transformou-se para a crítica e para a sociedade em nada mais do que uma concretização de incontáveis "coisas" que obscurecem seu real valor: o sentimento que lhes deu origem. Digno de admiração era tão somente o virtuosismo da representação objetiva (MALIÉVITCH apud CHIPP, 1999, p. 346).

O modo que Maliévitch encontrou para expor pictoricamente o seu modo de pensar, contrário à imitação da natureza, foi a escolha de uma forma que não existe na própria natureza: o quadrado. O Quadrado Preto (Figura 38) foi considerado por Maliévitch como o primeiro passo para a criação pura na arte, se encontra entre o apagamento de uma realidade material e a manifestação de um mundo sem objetos. A obra em questão não foi o resultado de um processo de abstração ou estilização. O Quadrado foi uma proposta de uma nova ordem puramente pictórica, em que cada forma é livre, individual e independe de aparências naturalistas, um modo 
de captar e mostrar o sentimento não objetivo ao mundo. $\mathrm{O}$ artista refugiou-se na forma de um quadrado e afirmou a necessidade desesperada de libertar a arte da objetividade.

Sobre este aspecto:

Mas o sentimento recompensador da não-objetividade libertadora impeliu-me para o deserto, onde nadaé concreto além do sentimento [...] Esta vida não era o "quadrado vazio" que eu havia exposto, mas o sentimento da não-objetividade (MALIÉVITCH apud CHIPP, 1999, p. 346).

Apesar de Maliévitch datar o primeiro Quadrado Preto em 1913, sabe-se que a obra foi concluída em 1915. O artista considerou o ano em que foi iniciada a ideia, na ópera Vitória Sobre o Sol, em 1913. São consideradas ao menos três versões do Quadrado Preto (Figura 41), tendo sido feita a última no final da década de 1920. 
Figura 41 - K. Maliévitch: Quadrado Preto - c. 1914

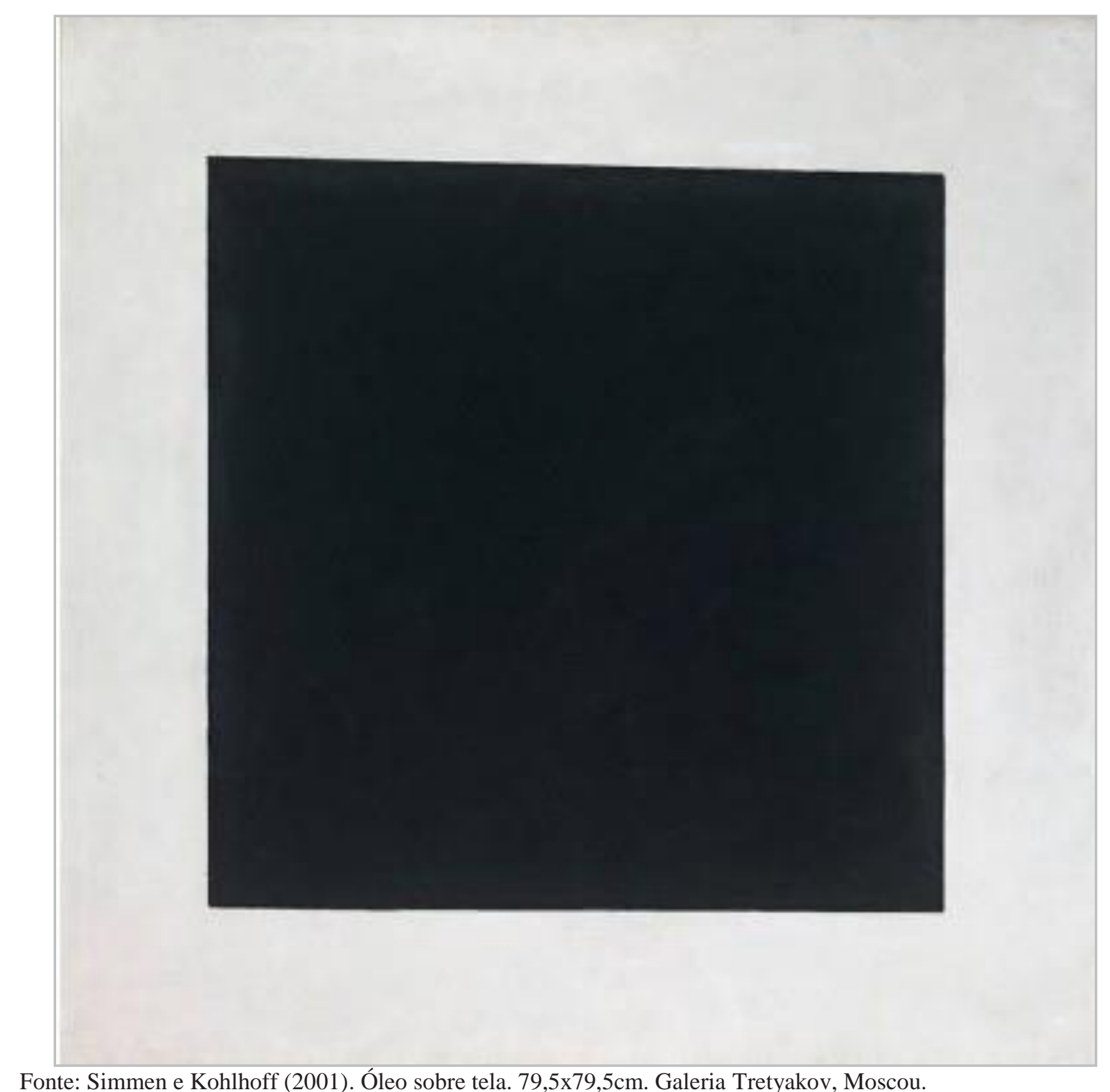

Sobre o Quadrado Preto:

O Quadrilátero Negro constitui, assim, a primeira redefinição satisfatória, em termos visuais e conceptuais, do tempo e do espaço na arte moderna. [...] tem uma elegante simplicidade que esconde o enorme esforço necessário para se conseguir sintetizar um conjunto de ideias complexas, reduzindo-as a uma 'lei' fundamental (JANSON, 1998, p. 689).

Maliévitch acreditava na existência de uma harmonia universal, que o homem poderia acessá-la caso possuísse um espírito puro e livre de conflitos. De acordo com Maliévitch (apud CHIPP, 1999, p. 345), “[...] o Suprematismo é a supremacia do sentimento puro na arte plástica”. Os suprematistas entendem que os fenômenos visuais do mundo objetivo não têm em si qualquer 
significado. Essencial é o sentimento como tal, completamente independente do meio em que foi evocado.

Como exemplo desse pensamento:

A ascensão às alturas da arte não objetiva é cansativa e cheia e tormentos, e ainda assim nos torna felizes [...] 'tudo aquilo que um dia gostamos e de que vivemos' - torna-se invisível. Não há mais 'imagens da realidade', não há mais representações ideais, nada há mais, a não ser um deserto! [...] O êxito da liberdade não-objetiva me levou porém para o deserto, onde não existe outra realidade a não ser a sensibilidade... - e, assim, a sensibilidade tornou-se o único conteúdo da minha vida (MALIÉVITCH apud DE MICHELLI, 2002, p. 233-234).

Para o suprematista, o meio de representação apropriado é sempre aquele que possibilita a representação tão completa quanto possível do sentimento como tal, que ignora o aspecto familiar dos objetos. Enquanto a arte do passado estava a serviço da religião e do estado, a arte pura do Suprematismo quer o despertar de uma vida nova e a construção de um mundo novo: o mundo do sentimento. $\mathrm{O}$ sentimento como elemento determinante possibilita a arte chegar a uma representação não objetiva. Tudo o que determinava uma estrutura ou ideal da arte, sejam ideias, sejam conceitos, sejam concepções, o artista deve rejeitar e dar espaço ao sentimento puro.

Sobre o Manifesto Suprematista:

Os suprematistas, ao contrário, deixaram de lado a representação da face humana (da objetividade naturalista) e encontraram novos traços para a reprodução direta dos sentimentos (e não dos reflexos "exteriorizados" dos sentimentos) pois o suprematista não observa nem tateia, sente (MALIÉVITCH apud CHIPP, 1999, p. 349).

Apesar de entender a importância do Cubismo e do Futurismo para as artes visuais e realizar muitas obras seguindo essas correntes, Maliévitch questionou as limitações cubistas pelo fato de as obras mostrarem somente os três lados dos objetos, seguindo orientações acadêmicas. O artista também questionou a razão e a lógica que oprimem a força do espontâneo e afirmou que quem sente a pintura vê menos o objeto. Com relação às limitações do Futurismo, Maliévitch questionou o fato de as obras ficarem datadas, pois, além de o processo de evolução das máquinas ser constante, a pintura sempre estaria submetida a algum tipo de ilustração relacionada ao objeto.

Sobre essa questão:

[...] a cultura pictórica deve seguir sem-objeto, como publiquei em 1915, no opúsculo do suprematismo como um novo realismo pictórico sem-objeto. Diantes do sem-objeto, devemos construir uma nova forma pictórica sem imitar as formas prontas, e, consequentemente, já nos direcionaremos para o caminho espontâneo da criação [...] (MALIÉVITCH, 2007, p. 51). 
Depois do quadrado, Maliévitch apresentou o Círculo Negro (Figura 42) como se fosse uma rotação do quadrado. O círculo foi posicionado no canto direito e superior da tela e está liberto da gravidade, como se flutuasse. Na pintura Cruz Negra (Figura 43), o artista dividiu dois retângulos irregulares que se unem num espaço plano. Em ambas as pinturas, as formas foram construídas sobre um fundo acinzentado, que representava um tipo de espaço cósmico. Para Maliévitch, o quadrado, o círculo e a cruz não eram simples formas não figurativas. Sobre esse aspecto, o artista retornou aos cânones da antiga arte russa, interpretando-a de forma peculiar. Nos ícones, a cor branca representa a eternidade.

Figura 42 - K. Maliévitch: Círculo Negro - 1923

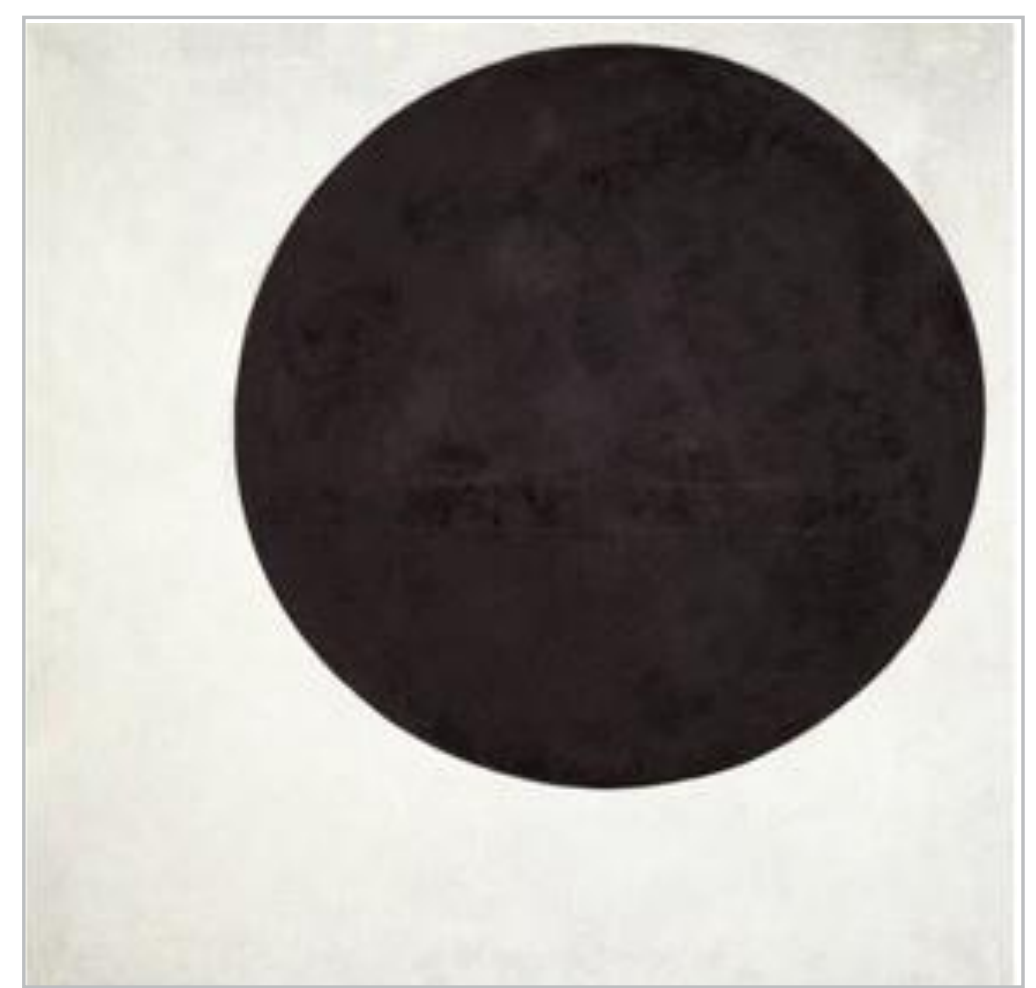

Fonte: Simmen e Kohlhoff (2001). Óleo sobre tela. 105x105cm. Museu do Estado Russo, São Petersburgo. 
Figura 43 - K. Maliévitch: Cruz Negra - 1923

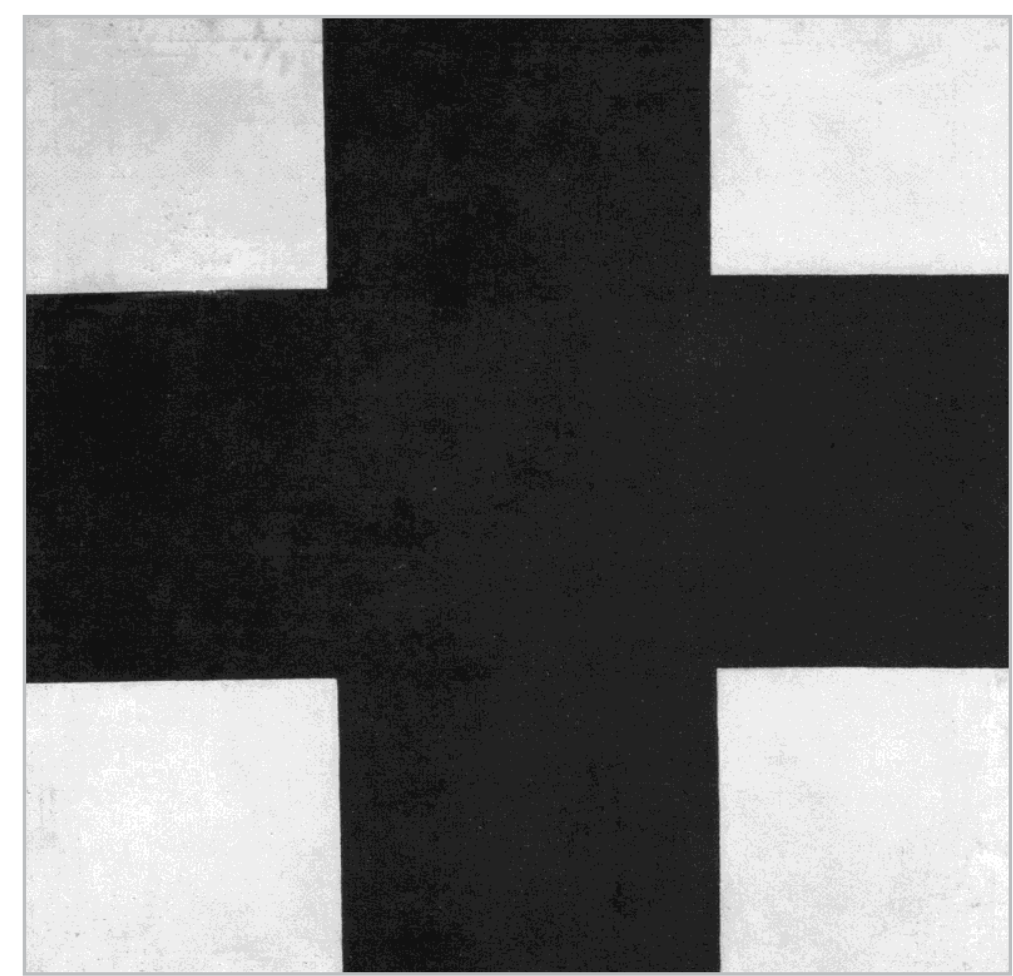

Fonte: Simmen e Kohlhoff (2001). Óleo sobre tela. 106x106cm. Museu do Estado Russo, São Petersburgo.

O quadrado, o círculo e a cruz foram utilizados pelos pintores de ícones como indicações de escuridão, inferno e sofrimento. Enquanto os antigos mestres pintavam inspirados na Sagrada Escritura, Maliévitch excluiu qualquer enredo, reduzindo as imagens a uma forma pura. Em vez do fundo vermelho ou dourado, típicos da iconologia, Maliévitch utiliza o fundo branco. Assim, o ícone ortodoxo russo volta na obra de Maliévitch com um aspecto modernizado (AGUILAR, 2002, p. 72).

Sobre isso o artista argumenta:

O Suprematismo não dá vida a um novo mundo de sentimentos, a uma nova representação direta ao mundo dos sentimentos.

O quadrado se modifica e dá origem a novas formas, cujos elementos são ordenados desta ou daquela maneira, de acordo com o sentimento que lhes deu origem (MALIÉVITCH apud CHIPP, 1999, p. 348).

O trabalho mais conhecido e comentado do Suprematismo é o Quadrado Preto. Na série em preto e branco, poderíamos concluir que pela ausência de cores e pela simplificação da forma ao extremo, o artista convida firmemente e silenciosamente o espectador a um mergulho nas profundezas do self. Pelo fato de essas obras fugirem do encantamento visual proporcionado pelo sensualismo da pintura de cavalete, o espectador, ao se deparar com uma pintura de extremo, não consegue escapar da sua realidade. Nesse aspecto, o artista não nos deixou opção. É como se 
buscássemos por respostas entre extremos que se completam, como a luz e a escuridão, yin-yang, material e espiritual, visível e invisível, razão e intuição.

O Quadrado Vermelho (Figura 44) foi apresentado pela primeira vez na 0.10. A última exposição futurista. No verso da pintura foi escrito: "Realismo Pictórico de Uma Camponesa em Duas Dimensões". O vermelho foi a primeira cor acrescentada à paleta depois do preto e do branco. Diferentemente do Quadrado Preto, que apresentava uma forma fechada, o Quadrado Vermelho salta para a frente da tela com cantos que parecem pulsar para fora. Em 1915, a Europa estava em guerra e a Revolução de 1917 na Rússia estava prestes a eclodir. Poderíamos deduzir a constante pressão emocional de viver numa época de guerra, revoluções e sangue derramado.

De acordo com essa percepção: "Púrpura representa o poder bizantino, vermelho é o sangue dos mártires, a nobreza czarista carrega a púrpura como insígnia da classe, vermelho é o comunismo, vermelho-sangue a revolução" (KRUNTORAD apud SIMMEN; KOHLHOFF, 2001, p. 48).

Para cada cor utilizada na pintura iconográfica há um significado. O vermelho é uma cor sempre presente. Significa o amor divino e o sangue que Cristo derramou para a vida do mundo.

Sobre Quadrado Vermelho:

Este título é uma prova evidente da busca, já nos meados dos anos 10, de uma imagem sincrética, na qual o símbolo da Rússia - a Camponesa, como Nossa Senhora nos ícones, possa ser representada de uma maneira lacônica e abrangente, uma nova forma descoberta por ela - a suprematista (AGUILAR, 2002, p. 72). 
Figura 44 - K. Maliévitch: Quadrado Vermelho - Realismo Pictórico da Camponesa em Duas Dimensões - 1915

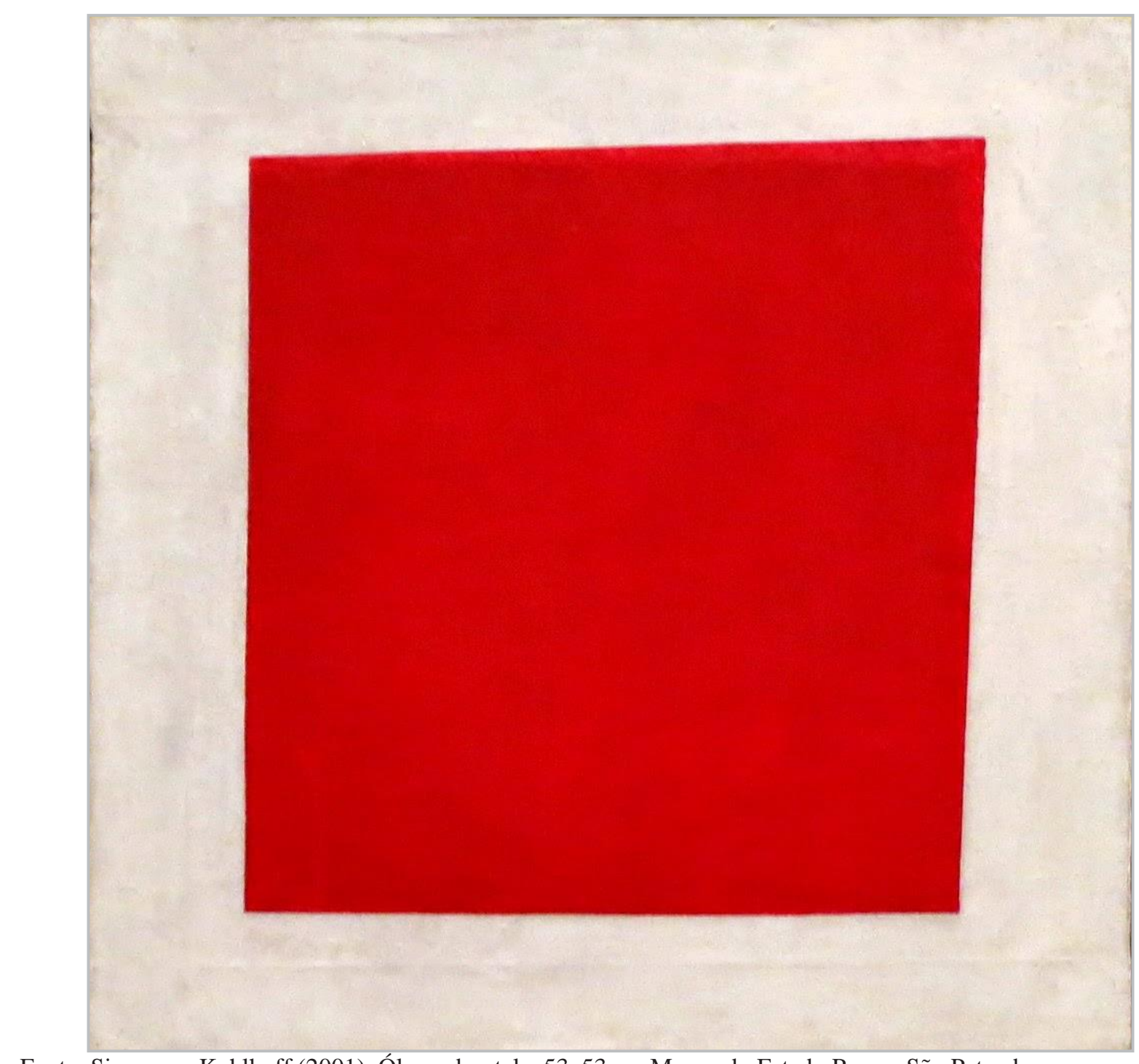

Fonte: Simmen e Kohlhoff (2001). Óleo sobre tela. 53x53cm. Museu do Estado Russo. São Petersburgo.

As obras suprematistas foram apresentadas ao público pela primeira vez na exposição 0.10. A última exposição futurista (Figura 45 e 46), na galeria particular Dobytchina, em Petrogrado. Essa exposição teve a participação de 14 artistas, que carregavam um objetivo em comum: esclarecer os motivos do rompimento com o Cubismo, Futurismo e com qualquer outro movimento simpatizante, para tomarem outro rumo. Houve muito desentendimento entre seus organizadores, tendo sido a principal causa da confusão o antagonismo entre Maliévitch e Tatlin, pois, num futuro próximo, Tatlin criaria outro movimento, o Construtivismo, que, entre outras ideologias, tinha como meta a criação de uma arte utilitária, ou seja, ideia oposta à defendida por Maliévitch. Tatlin chegou a declarar que as pinturas de Maliévitch eram amadoras e não poderiam participar de uma exposição de pintores profissionais. Maliévitch, nessa altura, já tinha 
conseguido inúmeros seguidores e era visto como um líder da vanguarda, ou seja, não seria possível realizar a exposição sem ele. Depois de uma discussão exacerbada, decidiram pela separação das salas. As quarenta obras de Maliévitch ficariam numa sala exclusiva, em que seriam expostas também as obras de seus seguidores. Tatlin, nada satisfeito, colocou uma placa em cima da entrada da sala que continha suas obras com a escrita: Exposição de Pintores Profissionais. O famoso Quadrado Preto foi colocado no canto entre duas paredes. Esse local costumava ser utilizado para os ícones nas casas russas. As outras obras foram apresentadas entre as duas paredes. Maliévitch, além de apresentar suas obras suprematistas, também lançou um Manifesto e distribuiu o folheto Do cubismo e futurismo ao suprematismo. Em seu Manifesto, explicou sobre "o zero da forma" e sobre o fundo branco como: o vazio que se situa além deste sentimento.

Sobre isso o artista escreveu:

Somente quando tiver desaparecido o hábito da consciência de um indivíduo enxergar na pintura fragmentos da natureza, madonas e nus despudorados é que veremos uma composição puramente pictórica [...] A arte se move em direção ao fim da criação, a que ela mesma se propôs, e ao domínio das formas da natureza (MALIÉVITCH apud DEMPSEY, 2008, p. 104).

Figura 45 - Cartaz da Exposição “0.10” - 1915

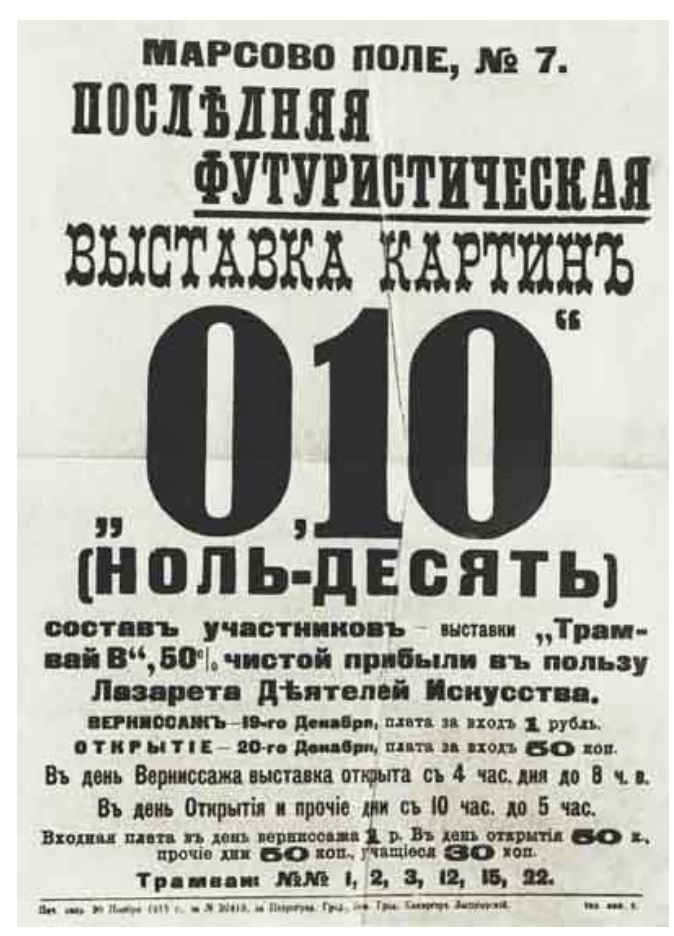

Fonte: Simmen e Kohlhoff (2001). 
Figura 46 - Foto da exposição “0.10. A última exposição futurista” - 1915

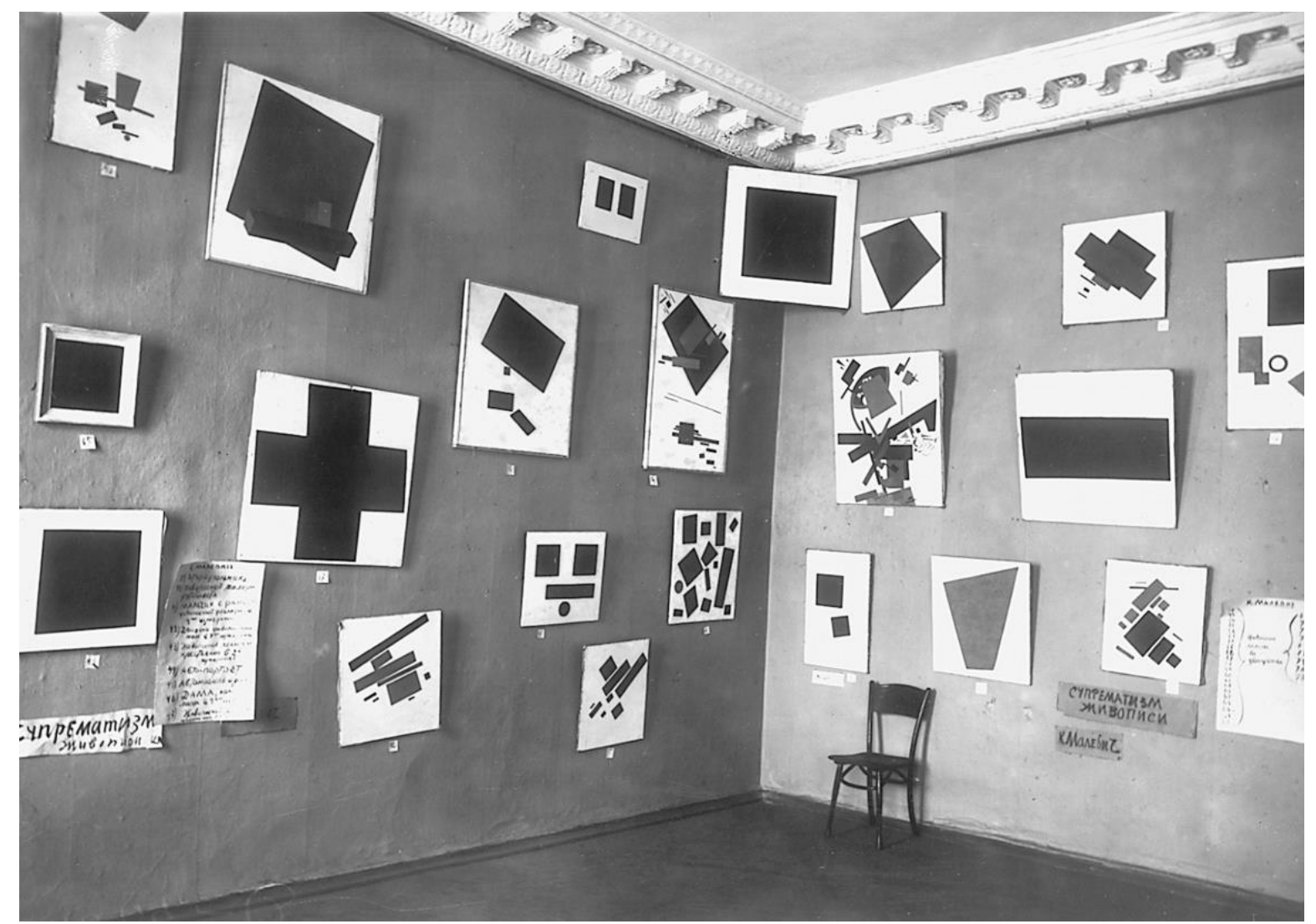

Fonte: Harrison, Frascina e Perry (1998).

A partir de 1915, o artista começa a introduzir novas relações cromáticas - o verde, o azul e o amarelo são acrescentados -, além de relações composicionais mais complexas. Nas obras Voo de Aeroplano (Figura 47), Autorretrato em duas Dimensões (Figura 48) e Suprematismo (Figura 49), barras retangulares se repetem com sobreposição de formas. Em Suprematismo (Figura 50), além das características já citadas, houve acréscimo de cores secundárias e uma forma orgânica na composição. Na Pintura Suprematista (Figura. 51), iniciase o acréscimo de sombra como forma de proporcionar uma terceira dimensão. A sombra é descrita pelo artista como símbolo de infinitude, como estrelas no cosmos. Podemos notar uma espécie de movimento entre os elementos do quadro. É como se estivessem pairando sobre um espaço gravitacional. Em cada momento seríamos surpreendidos com novas composições e rotações dos elementos, que ora se afastavam, ora se sobrepunham. Essa fase é denominada por alguns autores como Suprematismo Dinâmico. 
Figura 47 - K. Maliévitch: Composição Suprematista: Voo de Aeroplano - 1915 (datado de 1914)

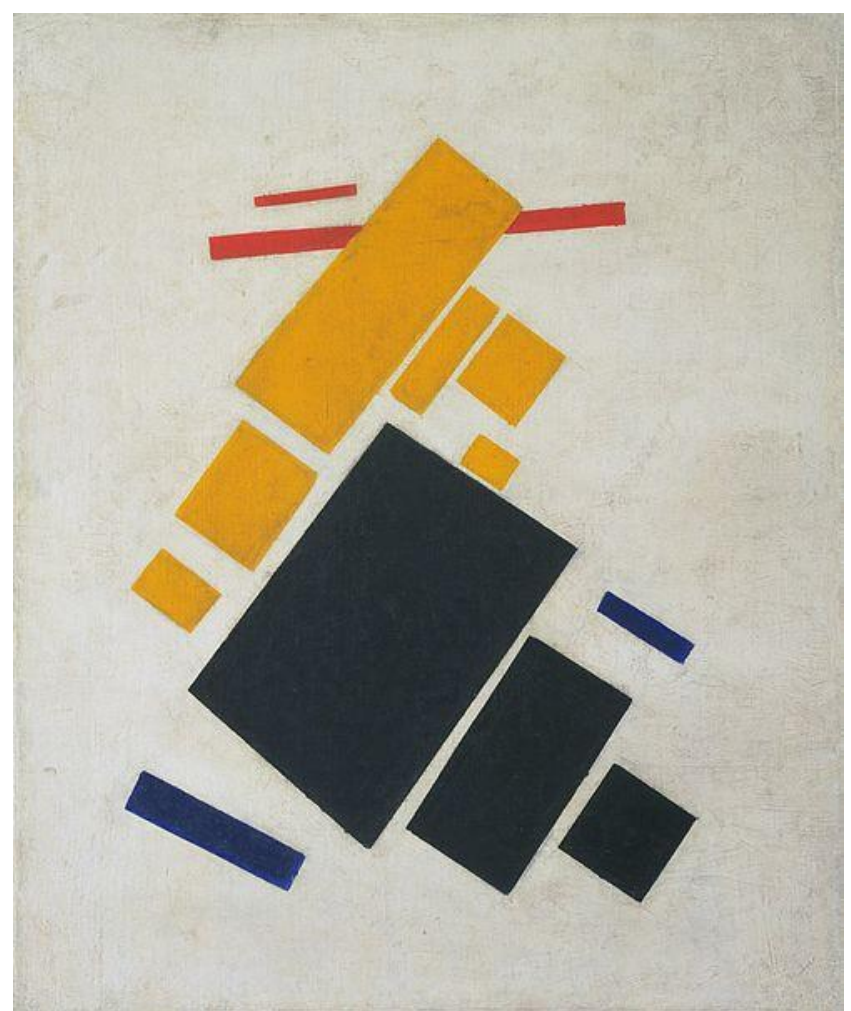

Fonte: Harrison, Frascina e Perry (1998). Óleo sobre tela. 58x48cm. Coleção, The Museum of Modern Art, Nova Iorque. 
Figura 48 - K. Maliévitch: Autorretrato em duas dimensões - 1915

Fonte: Bermejo (1995).

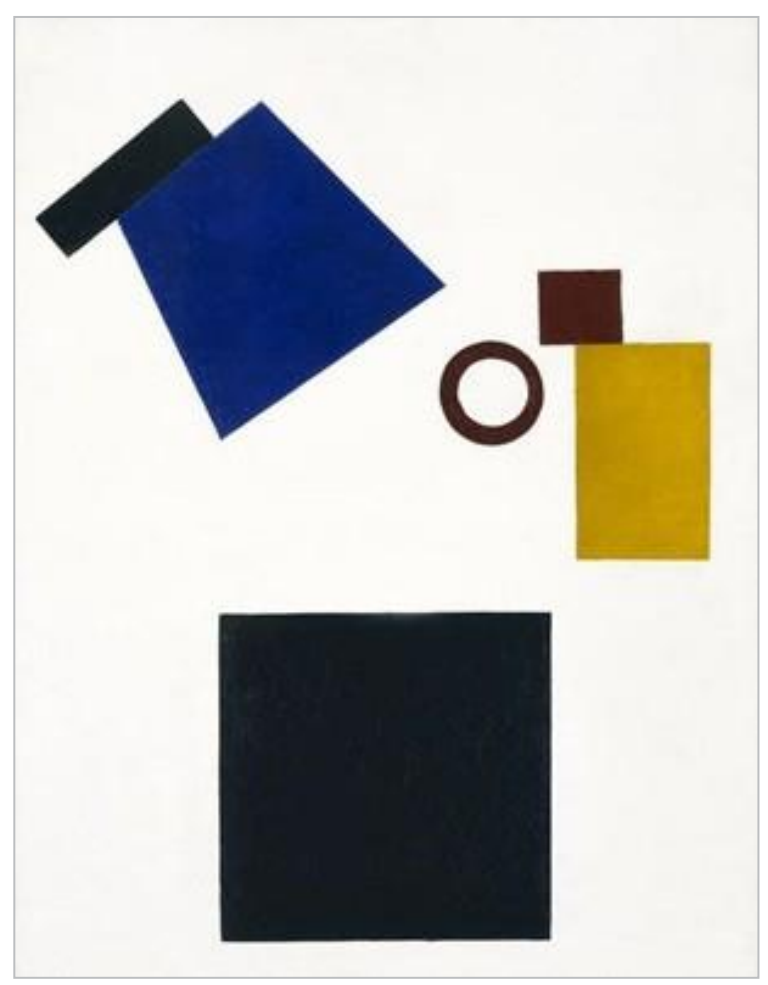

Figura 49 - K. Maliévitch: Suprematismo - 1916-1917

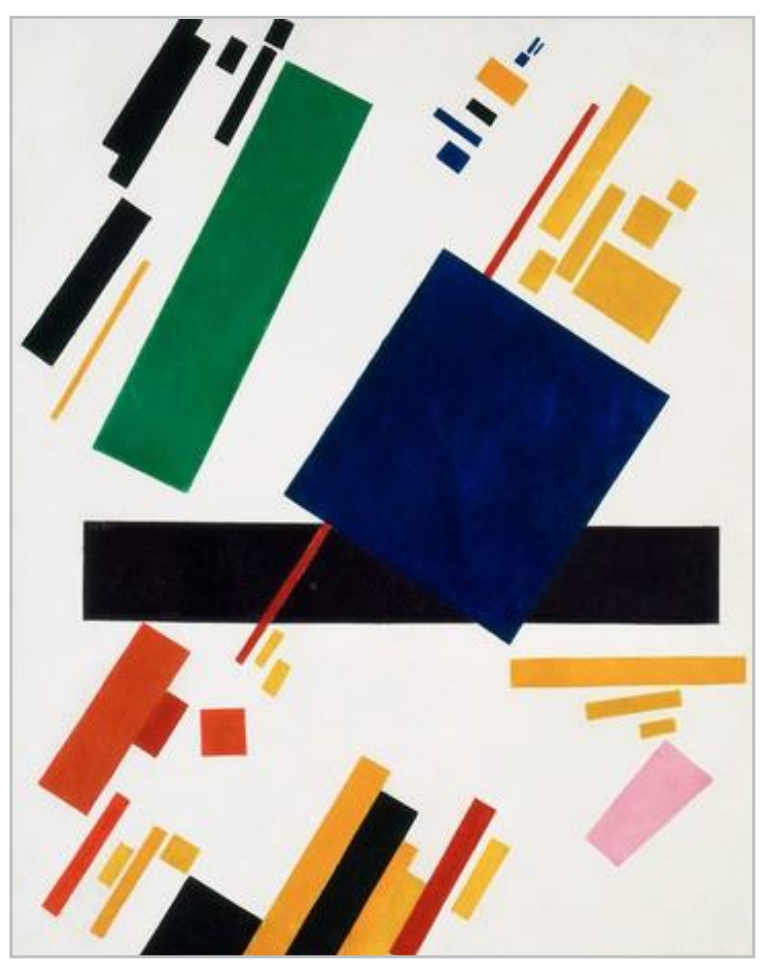

Fonte: Bermejo (1995). 
Figura 50 - K. Maliévitch: Suprematismo - 1916-1917

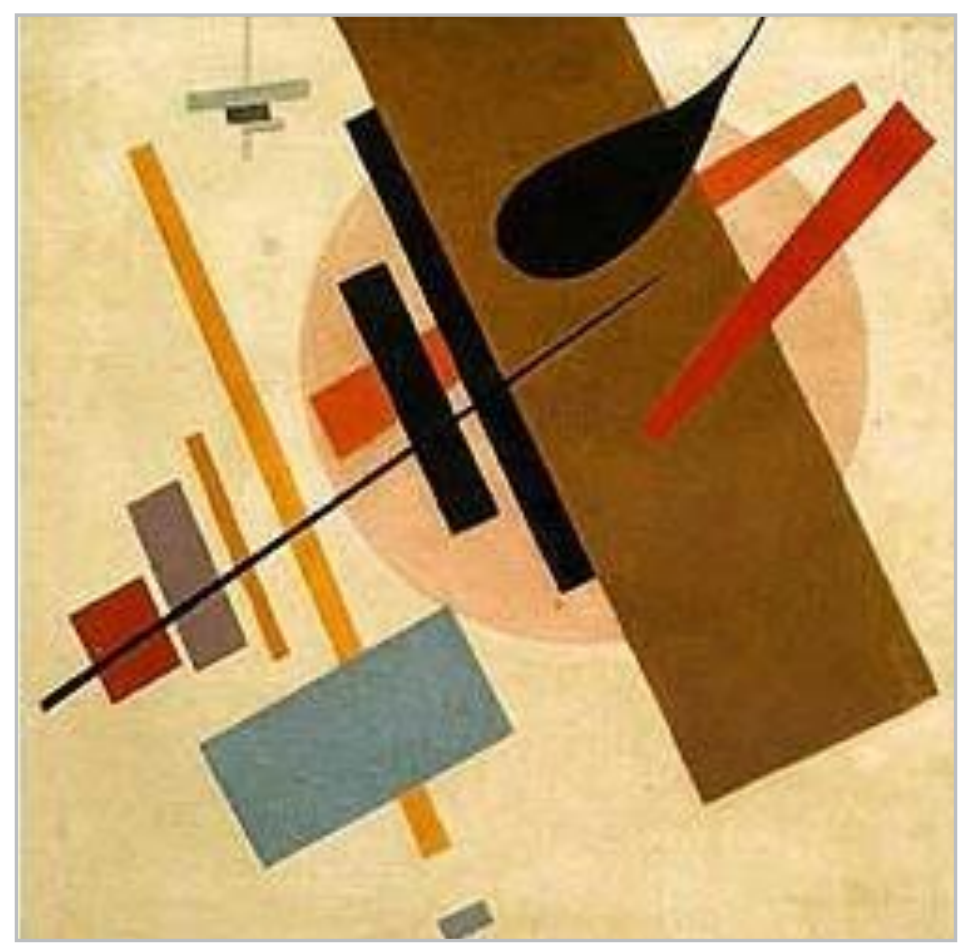

Fonte: Bermejo (1995).

Figura 51 - K. Maliévitch: Pintura suprematista - 1917-1918

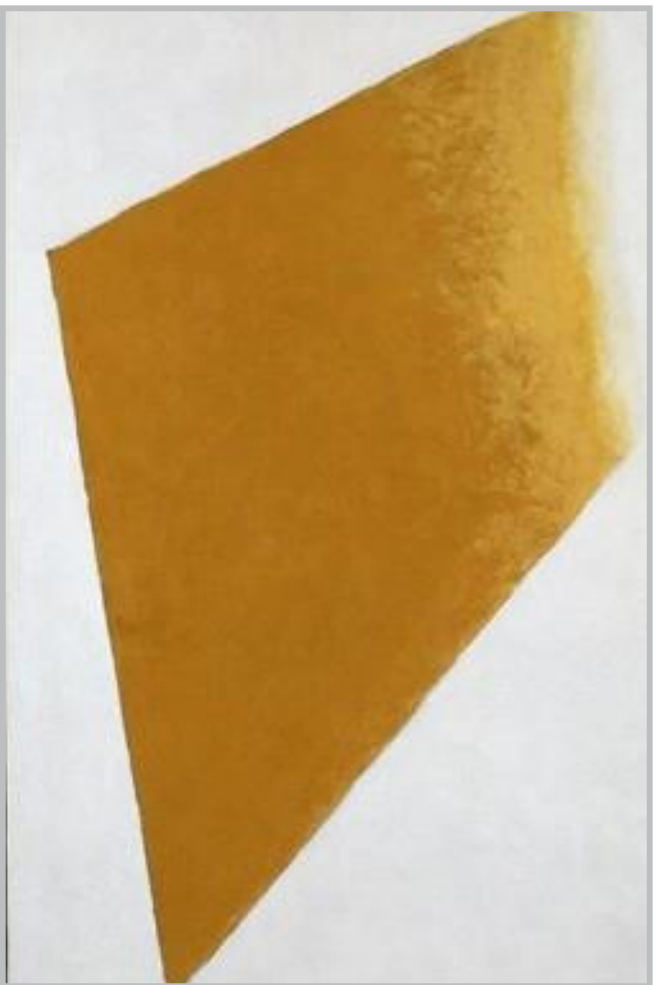

Fonte: Gray (2004). Óleo sobre tela. 106x70,5cm. Museu de Stedelijk, Amsterdã. 
Depois de as obras suprematistas terem sido apresentadas ao público na 0.10. A última exposição futurista, Maliévitch organizou com outros artistas uma discussão aberta sobre o Suprematismo na Escola Tenisheva de Artes Decorativas, em Petrogrado. A palestra foi anunciada como Dos movimentos surgidos na exposição 0.10, e foram discutidos temas relacionados ao Cubismo e ao Futurismo. Inclusive, nesse evento, o artista demonstrou, ao vivo, uma pintura cubista até chegar ao suprematismo. O artista não tinha o apoio de críticos, mas tinha um grande número de seguidores, a ponto de a imprensa reconhecer que o Suprematismo era o movimento predominante entre os artistas. Maliévitch foi um dos artistas mais utópicos da década de 1920. Acreditava que os problemas de existência social de sua época seriam resolvidos somente se o planejamento fosse conduzido pelo desenvolvimento da arte abstrata.

Sobre isso:

O projeto de vanguarda de Maliévitch, que havia começado no antinaturalismo e no antirracionalismo futurista, foi portanto continuado como uma campanha ambiciosa pela autonomia da criação e da forma artística. De fato, ele parece ter acreditado que a universalidade potencial e a autonomia formal absoluta da arte suprematista a qualificam, não simplesmente como o mais atualizado estilo de vanguarda, mas sim como a base estética potencial para toda uma nova ordem mundial (HARRISON; FRASCINA; PERRY, 1998, p. 238).

Na Décima Exposição Estatal: Criação Abstrata e Suprematismo, ápice da pintura abstrata na Rússia, Maliévitch apresentou uma série de pinturas monocromáticas, entre elas o Quadrado Branco sobre Fundo Branco (Figura 52) e a Pintura Suprematista (Figura 53). As pinturas tinham elementos branco-azulados, frios, enquanto as bases eram branco-cremosas, quentes. Essa fase, considerada como a última fase do Suprematismo, ideia confirmada pelo artista, pode ser considerada como o apogeu do Movimento. A figura do quadrado não está nem à frente nem atrás. Encontra-se num equilíbrio entre brancos, em que figura e fundo se fundem, e levita num espaço que imita o cosmos, como se não houvesse lei da gravidade. 
Figura 52 - K. Maliévitch: Quadrado branco sobre fundo branco - 1918

Fonte: Simmen e Kohlhoff (2001). Óleo sobre tela.78,7x78,7cm. Museum of Modern Art, Nova Iorque. 
Figura 53 - K. Maliévitch: Pintura Suprematista - 1917-1918

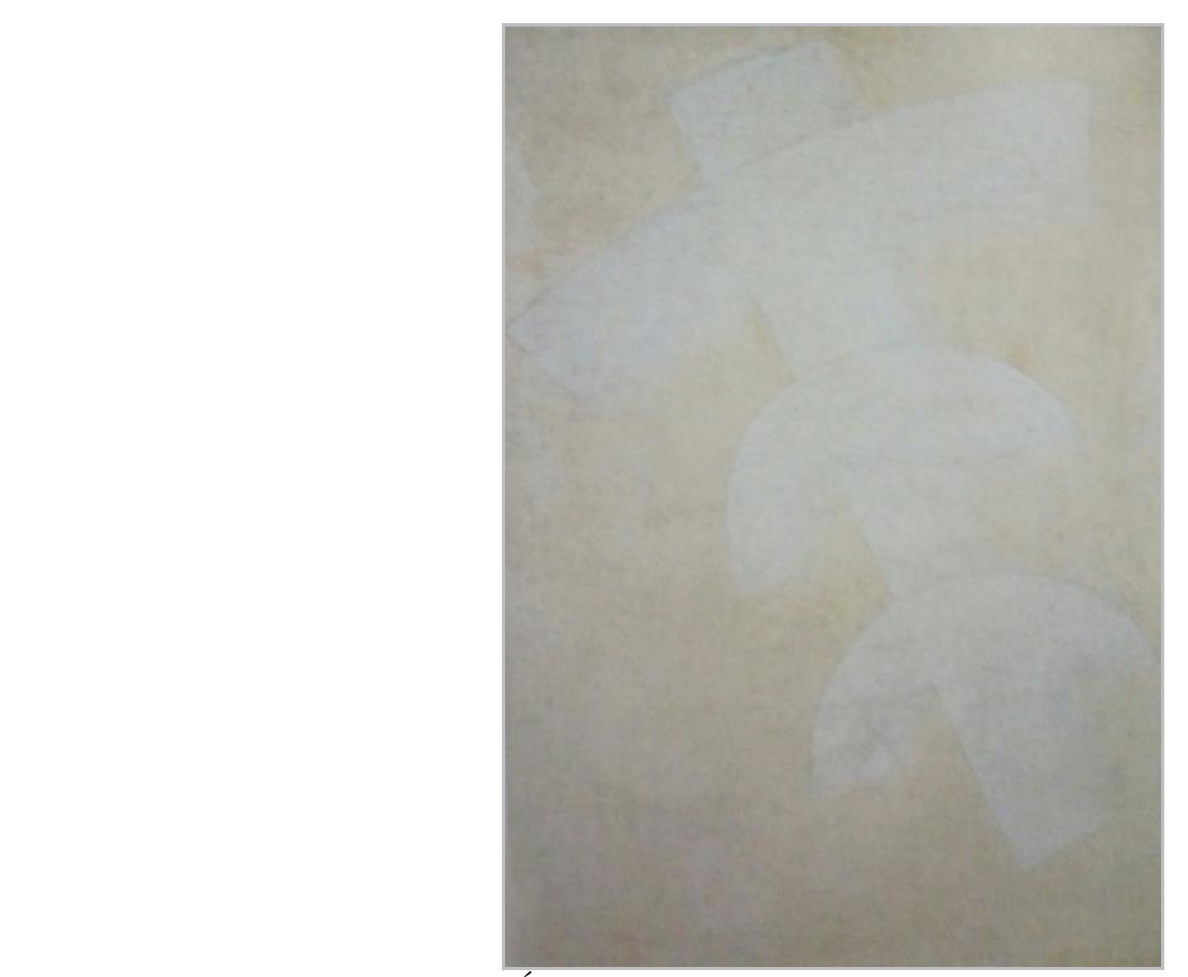

Fonte: Simmen e Kohlhoff (2001). Óleo do sobre tela. 97x70cm. Stedelijk Museum, Amsterdã.

Com relação ao Quadrado Branco sobre Fundo Branco:

[...] Ignoramos realmente o que Malevich pretendeu representar. Mas, no contexto de suas outras obras e considerando suas próprias declarações, não será audacioso demais supor que pretendia transmitir algo como a emancipação final: um estado de nirvana, a afirmação final da consciência suprematista. O quadrado (a vontade humana, talvez o homem?) solta a sua materialidade e funde-se com o infinito. Um tênue vestígio de sua presença é tudo o que resta (SCHARF, 2000, p. 101-102).

Segundo a tradição dos ícones, o branco está associado à pureza. A monocromia, nesse caso, poderia ser associada a um convite à transcendência e à purificação. $\mathrm{O}$ branco também poderia ser justificado como o princípio de tudo, em que não há nada.

For Malevich, the monochrome was both a spiritual icon to be displayed as religious images were traditionally seen in Russia, as well as a step in the revolutionary process toward the elimination of the objetc [...] The idea was to create a space as limitless as the sky, which would transcend the limited boundaries of the canvas ${ }^{13}$ (ROSE, 2004, p. 27).

Seguindo a Teoria do Elemento Adicional, em que o artista é completamente influenciado pelo meio em que vive, devido ao fato de a Rússia apresentar uma temperatura abaixo de zero durante vários meses do ano, torna-se comum para um cidadão russo conviver

13 "Para Malevich, o monocromático era um ícone espiritual a ser exibido como as imagens religiosas eram tradicionalmente vistas na Rússia, como também um passo no processo revolucionário para a eliminação do objetivo [...] A ideia era criar um espaço tão ilimitado quanto o céu, que transcenderia os limites limitados da tela". 
com a neve e com o branco, sempre presentes em paisagens urbanas e provinciais. O convívio com o branco passou a ser uma constante que trouxe como consequência influências para a criação da série de pinturas branco sobre branco.

No catálogo da exposição o artista escreveu: "Rompi a barreira do azul das fronteiras da cor e desemboquei no branco. Atrás de mim meus colegas pilotos nadam na brancura. Finquei o semáforo do suprematismo. Nadem!" (MALIÉVITCH apud DEMPSEY, 2008, p. 104).

Depois da última exposição em grupo, em 1919, Maliévitch realizou uma mostra individual: Do Impressionismo ao Suprematismo (Figura 54). Nessa mostra, ele comunica que o Suprematismo, como movimento em pintura, havia terminado. Afirma que a cruz que estivera presente em muitos de seus trabalhos é a sua própria cruz e que ele sentia essa "morte da pintura" (GRAY, 2004).

\section{Figura 54 - Exposição Do Impressionismo ao Suprematismo}

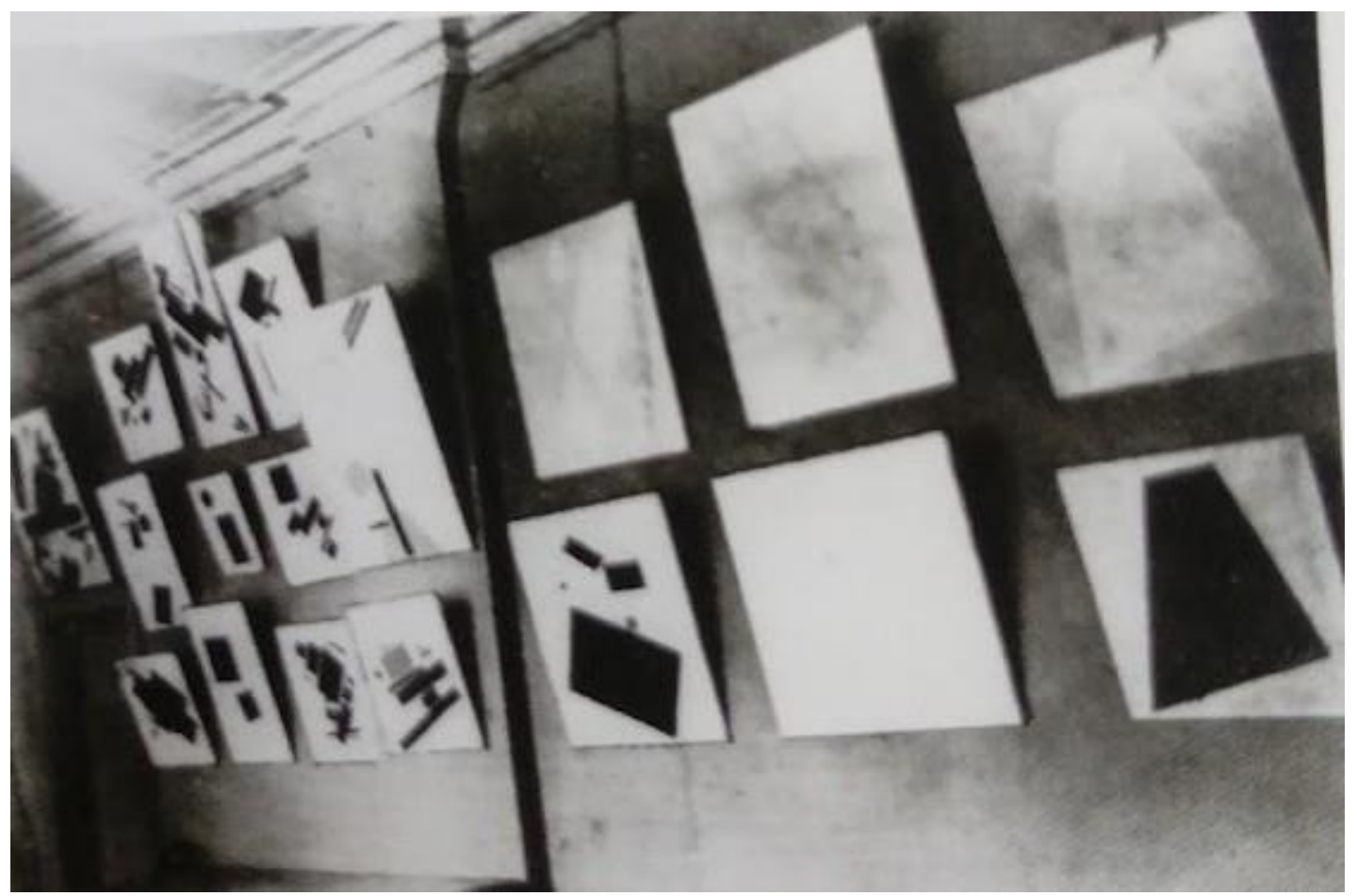

Fonte: Drutt (2003).

Ao analisarmos o percurso artístico na Rússia, notamos que até o início do século XX houve grande oscilação de influências e interesses. Ora a nobreza valorizava a arte que vinha de fora, no caso da Europa, em especial de Paris, ora a vanguarda e os dirigentes valorizavam a arte local de seus antepassados. Na década de 1910, com a abstração de Maliévitch, Kandinsky e outros artistas, houve um fortalecimento do universo artístico russo, fato que levou o cenário artístico para outra posição. Em vez de importar conceitos e movimentos, a Rússia começa a 
exportar conceitos e ideias artísticas. Infelizmente, o país passou por períodos de revoluções e guerra que o levaram a um isolamento por um longo período.

De acordo com essa percepção:

[...] as artes plásticas russas foram os primos pobres da história da arte, tão enraizada estava a ideia convencional de que, por mais que tivesse uma literatura inesgotável, uma música e um ballet originais, a Rússia não era um país de pintores. [...] na década de 1960, historiadores de arte como Camilla Gray, Troels Andersen, Valentine Marcadé, revelaram a amplitude do movimento pictórico russo no primeiro quarto do século XX [...] (AGUILAR, 2002, p. 83).

Na obra Quadrado Preto sobre fundo Branco, o próprio título já nos esclarece que, apesar de a pintura ser plana, o quadrado preto está à frente do fundo branco. Ao observarmos as obras dessa fase, incluindo as pinturas Círculo Negro e Cruz Negra, notamos uma forte rigidez na escolha das formas e do modo composicional, assim como na utilização tão explícita do preto e do branco. Com o propósito de criar novos signos para uma nova era, o artista tinha a intenção de criar um novo sistema, com novos significados.

Sobre esse aspecto:

The case of Malevich is unique in the history of art because he was both a great painter and a great thinker. Many painters from Leonardo da Vinci to Vasily Kandinsky have left their philosophical thoughts, but Malevich created an ontological system [...] (DRUTT, 2003, p. 35) ${ }^{14}$.

Considerando uma proposta de um mundo novo e sem objetos, poderíamos concluir que este "mundo novo" não teria um início tão fácil. O "preto no branco", sem nenhuma ilusão de profundidade, não nos permitiria viver de forma alguma fora da realidade. A realidade estava ali e dentro de nós, representada, talvez, como nunca fora anteriormente. Na segunda fase suprematista, chamada de Suprematismo Dinâmico, o artista começa a soltar os elementos no espaço. Inclusive, podemos notar essa característica em títulos como Voo de Aeroplano. Em vez de uma única forma, que ocuparia toda a dimensão do quadro, o artista adota várias formas, praticamente todas geométricas, e faz uma dança entre elas. Com relação às cores, primeiramente há o acréscimo de cores primárias e na sequência o artista utiliza também cores secundárias, oferecendo ao espectador literalmente um outro tom visual. A rigidez da primeira fase perde o espaço imposto e sem movimento, que dá a vez para os elementos flutuarem num espaço sem gravidade e sem opressão. Na considerada como última fase suprematista, a fase branco sobre branco, poderíamos dizer que o artista chegou a um estágio evolutivo pictórico e espiritual, que, ao nosso olhar, seria o ápice da evolução.

\footnotetext{
14 "O caso de Malevich é único na história da arte porque ele foi um grande pintor e pensador. Muitos pintores, de Leonardo da Vinci a Vasily Kandinsky, deixaram seus pensamentos filosóficos, mas Malevich criou um sistema ontológico".
} 
Essa evolução o artista aprendeu com ele mesmo. Ao observarmos o percurso dessa fase suprematista, percebemos nitidamente a trajetória rumo à evolução. No Quadrado Branco sobre Branco, poderíamos entender que toda a efervescência sobre os aspectos contraditórios humanos poderia ser resolvida nessa obra. Não há mais disputas. Agora tudo é branco, tudo é igual, não há mais também figuras à frente de um fundo. Agora tudo está lado a lado, sem sobressaltos. Não há mais nada à frente de nada. Apesar da utilização de uma única forma e do retorno ao quadrado, dessa vez o quadrado flutua, estando literalmente solto no universo. Aliás, ele passa a ser o próprio universo.

Depois dessas fases, o Suprematismo toma outros rumos e retorna à figuração. A proposta inicial do artista (que afirma que tudo muda o tempo todo) de que somos parte da natureza nos leva a conclusão de que, depois de uma tarefa cumprida, podemos retornar novamente a um outro início, para daí seguirmos rumo a novos caminhos de evolução.

\subsection{A figuração no Suprematismo}

Depois da revolução de outubro de 1917, com a queda do czarismo, a nova ordem seria baseada na industrialização. Maliévitch acreditava que a arte havia sido um arsenal em que a sociedade se baseara para crescer e perceber a necessidade de uma revolução. Sobre isso ele diz: "O cubismo e o futurismo foram as formas revolucionárias da arte que prenunciaram a revolução na vida política e econômica de 1917” (MALIÉVITCH, 1920 apud GRAY, 2004, p. 115).

O Departamento de Belas Artes foi criado em 1918 com o objetivo de cuidar e organizar a vida artística do país. No período da Revolução de 1917 até 1926, Maliévitch ocupou alguns postos importantes no sistema educacional-artístico na União Soviética. Em 1920, pôs em prática, na Escola de Artes de Vitebsk um método de ensino baseado no Suprematismo como um sistema completo e universal que seria realizado com um trabalho coletivo. Esse grupo foi denominado Unovis (Figura 55). 


\section{Figura 55 - Grupo Unovis}

Fonte: Drutt (2003).

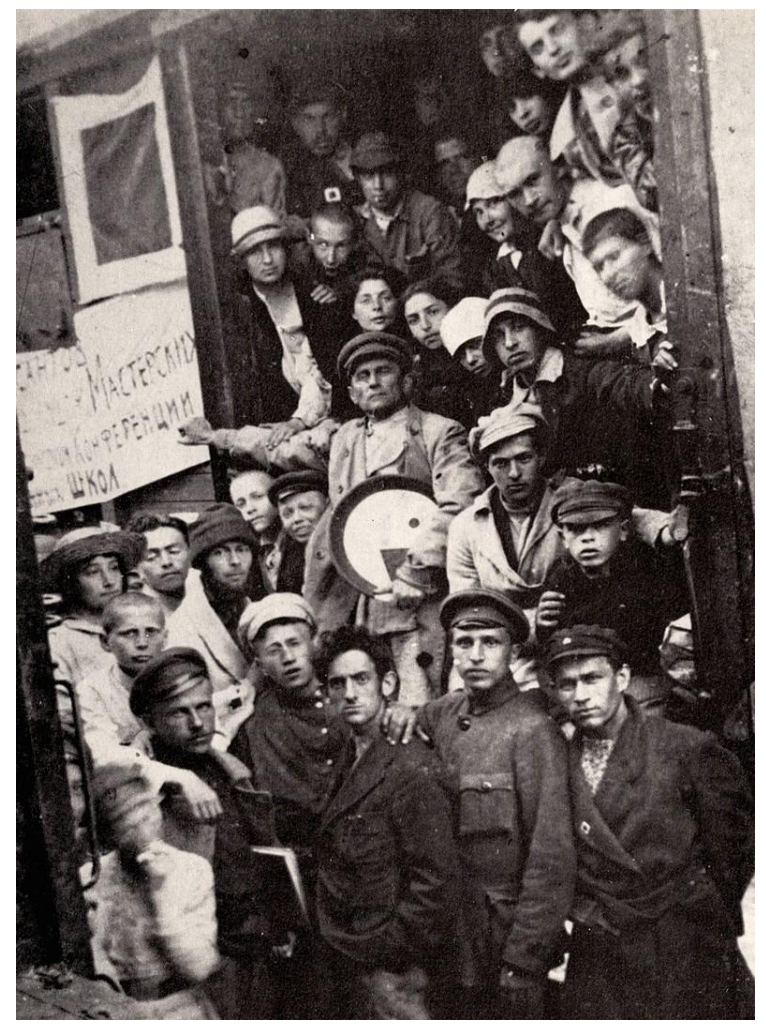

O grupo optou por não assinar o nome do artista nas obras produzidas. As obras eram assinadas com um quadrado, que, além de representar o ideal suprematista, compartilharia a autoria e a responsabilidade por todos os trabalhos produzidos. Notamos que o fato de o grupo não buscar a possível fama advinda de uma autoria, compartilhava dos ideais marxistas da época. Entre 1923 e 1928, na Galeria de Cultura Artística, em Petrogrado, local em que também residiu, Maliévitch foi responsável pelo laboratório de pintura experimental, que tinha como objetivo estabelecer uma teoria crítica sobre a história da arte. O artista implementou o GINKhUK, regime de pesquisa entre 1924-1926. Em 1927, Maliévitch foi convidado a fazer uma exposição em Berlim (Figura 56), e acreditou-se que ele havia tentado iniciar uma nova carreira no Ocidente, pois nessa viagem levou consigo um grande volume de material teórico, no qual estava incluída a inédita: Teoria do Elemento Adicional na Pintura. Esse ensaio foi publicado na Alemanha em 1929. 
Figura 56 - K. Maliévitch: Exposição - 1927

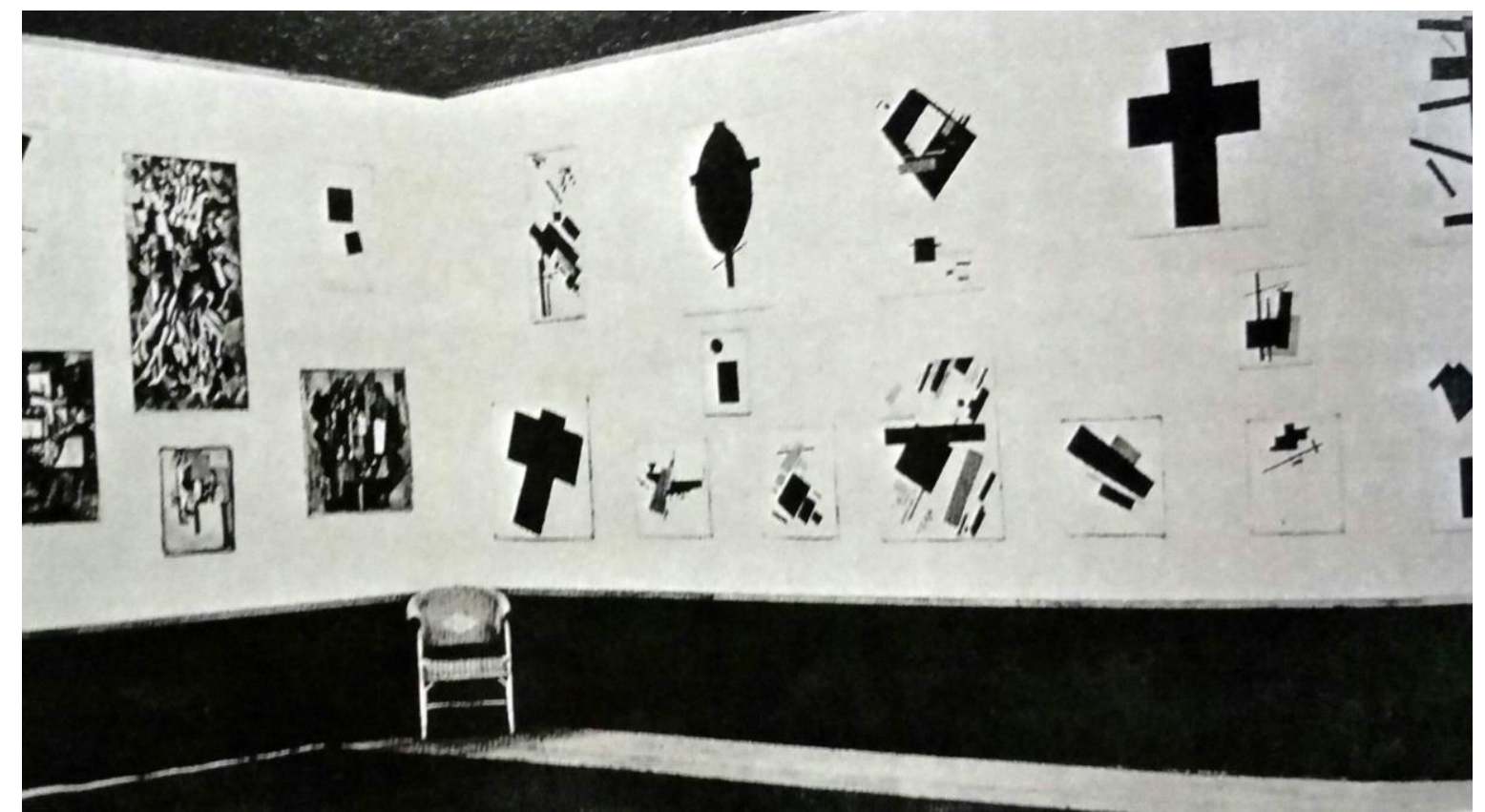

Fonte: Simmen e Kohlhoff (2001).

O trabalho de Maliévitch era incompreensível para os historiadores de arte. Em 1929, o artista e seus seguidores foram expulsos do departamento do Instituto Estatal.

Com a morte de Lenin em 1924, o estado cede ao stalinismo, e a arte realista passa a ganhar força, tornando-se um agente de propaganda do poder. A consagração do realismo socialista acabou gerando um silêncio na vanguarda russa. Maliévitch, que já havia retornado à figuração, pintou figuras de camponeses em formato de cruz (Figura 57), além de camponeses sem braço, como se estivessem envolvidos num colete de força (Figura 58). O artista apresentou as obras figurativas com as obras suprematistas, afirmando existir coerência entre ambas. Em 1928, Maliévitch afirma, em uma de suas cartas, uma nova etapa de sua criação. Nesse período, ele continua a busca por novas formas do Suprematismo. 
Figura 57 - K. Maliévitch: Figura de braços estendidos em cruz - 1933

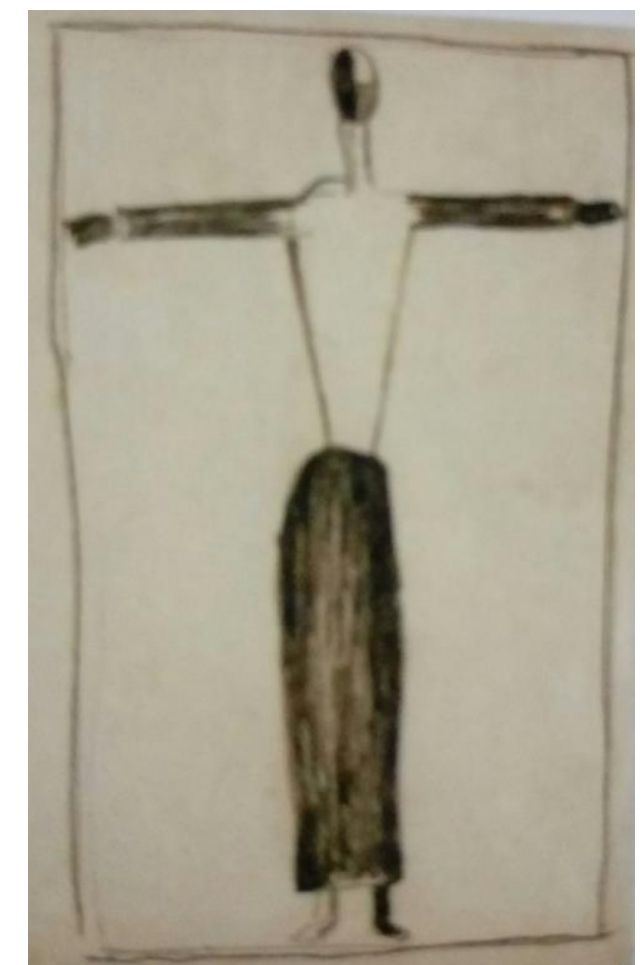

Fonte: Simmen e Kohlhoff (2001). Lápis sobre papel. 36x22,5cm. Ludwig Museum, Colónia.

Figura 58 - K. Maliévitch: Suprematismo. Figura Feminina - 1928-1932

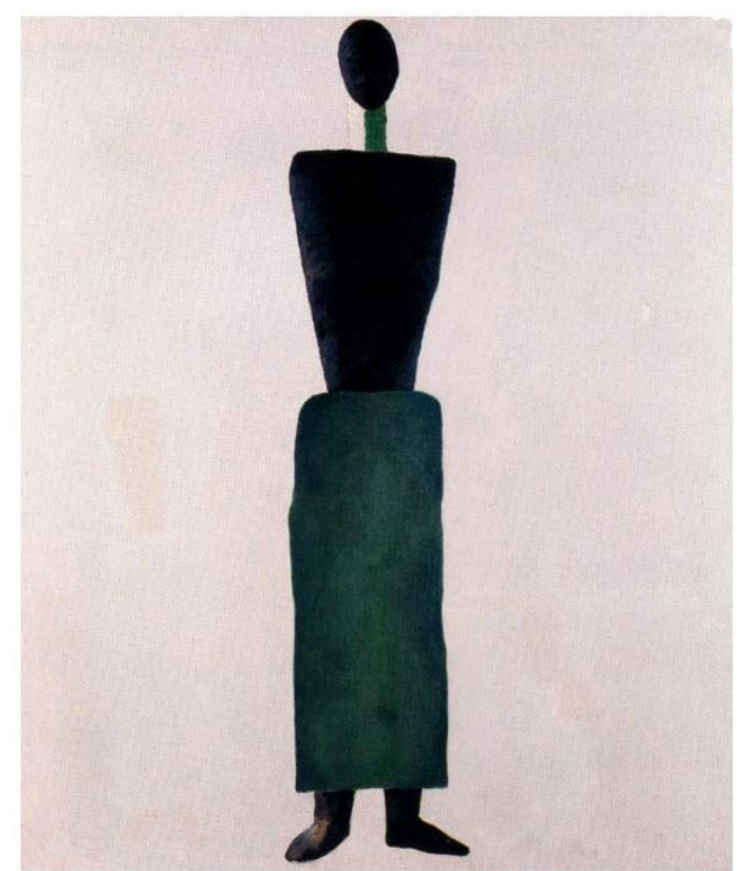

Fonte: Simmen e Kohlhoff (2001). Óleo sobre tela. 126x106cm. Museu do Estado Russo, São Petersburgo.

Em seu retorno à pintura figurativa, o artista opta por enfatizar a figura do homem do campo, entre outros temas. Notamos que a característica do indivíduo sem rosto, que o acompanha desde o início de suas pinturas, continua presente. Há uma lógica simétrica nas obras 
e volta-se à figura e fundo, apesar de não utilizar perspectiva, somente diferenças de planos. Notamos também o predomínio de cores fortes e a preferência pelas cores primárias. Essas caraterísticas podem ser validadas nas obras Torso feminino (Figura 59), Camponeses (Figura 60) e Esportistas (Figura 61), e em outras telas pintadas entre 1928-1932.

\section{Figura 59 - K. Maliévitch: Torso feminino - 1928-1932}

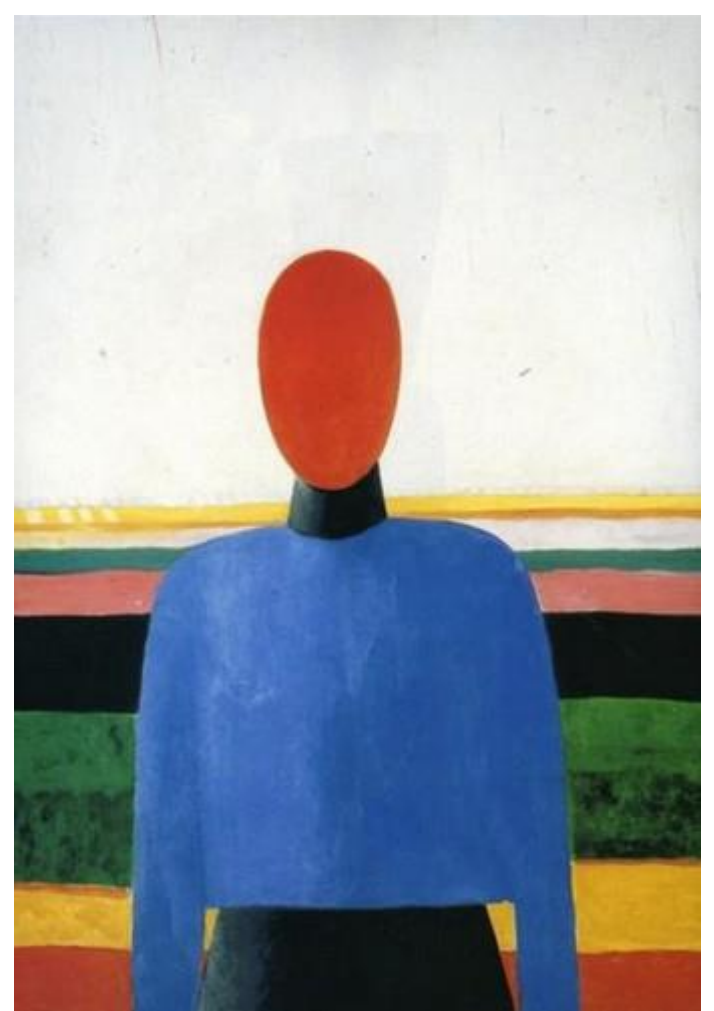

Fonte: Aguilar, 2002. Óleo sobre madeira. 73x52,5cm. Museu do Estado Russo, São Petersburgo. 
Figura 60 - K. Maliévitch: Camponeses no campo - 1929

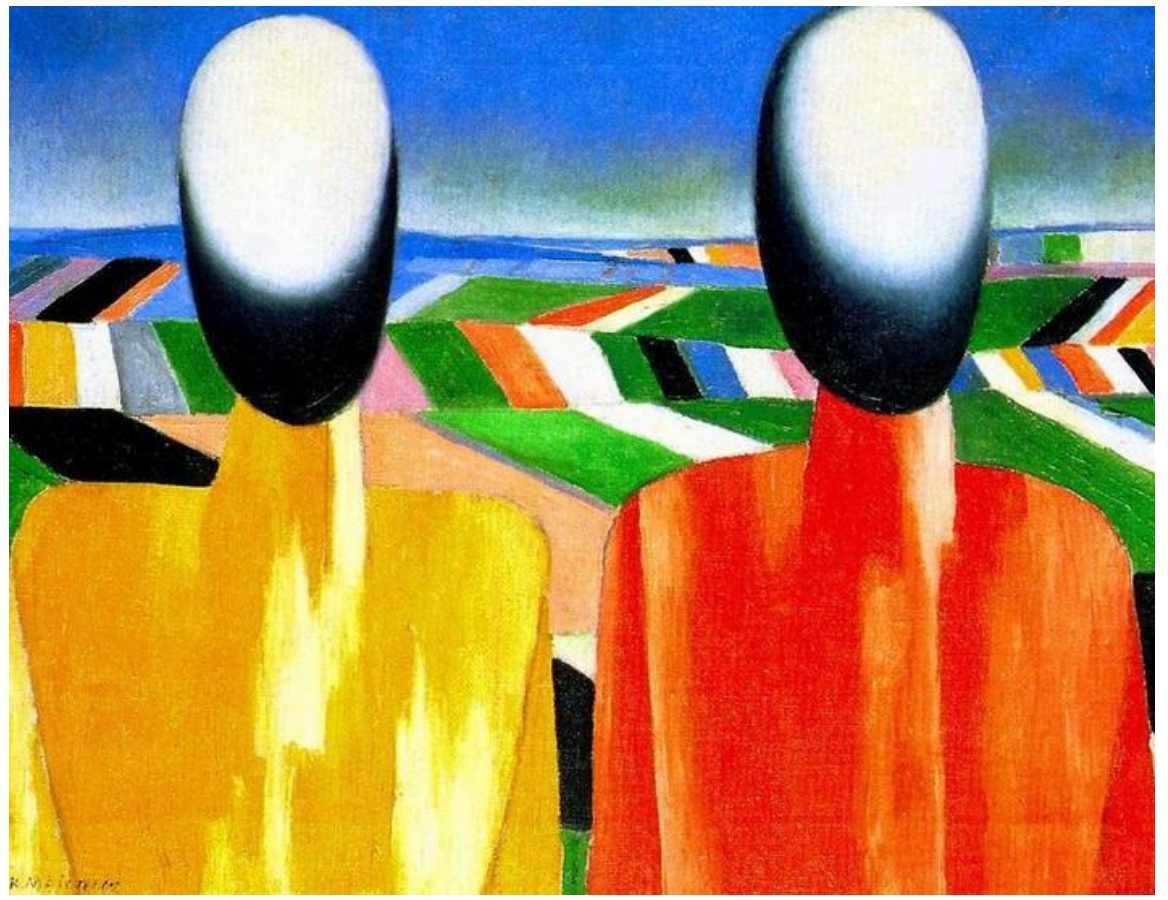

Fonte: Souter. Museu do Estado Russo, São Petersburgo.

Figura 61 - K. Maliévitch: Esportistas - 1930-1932

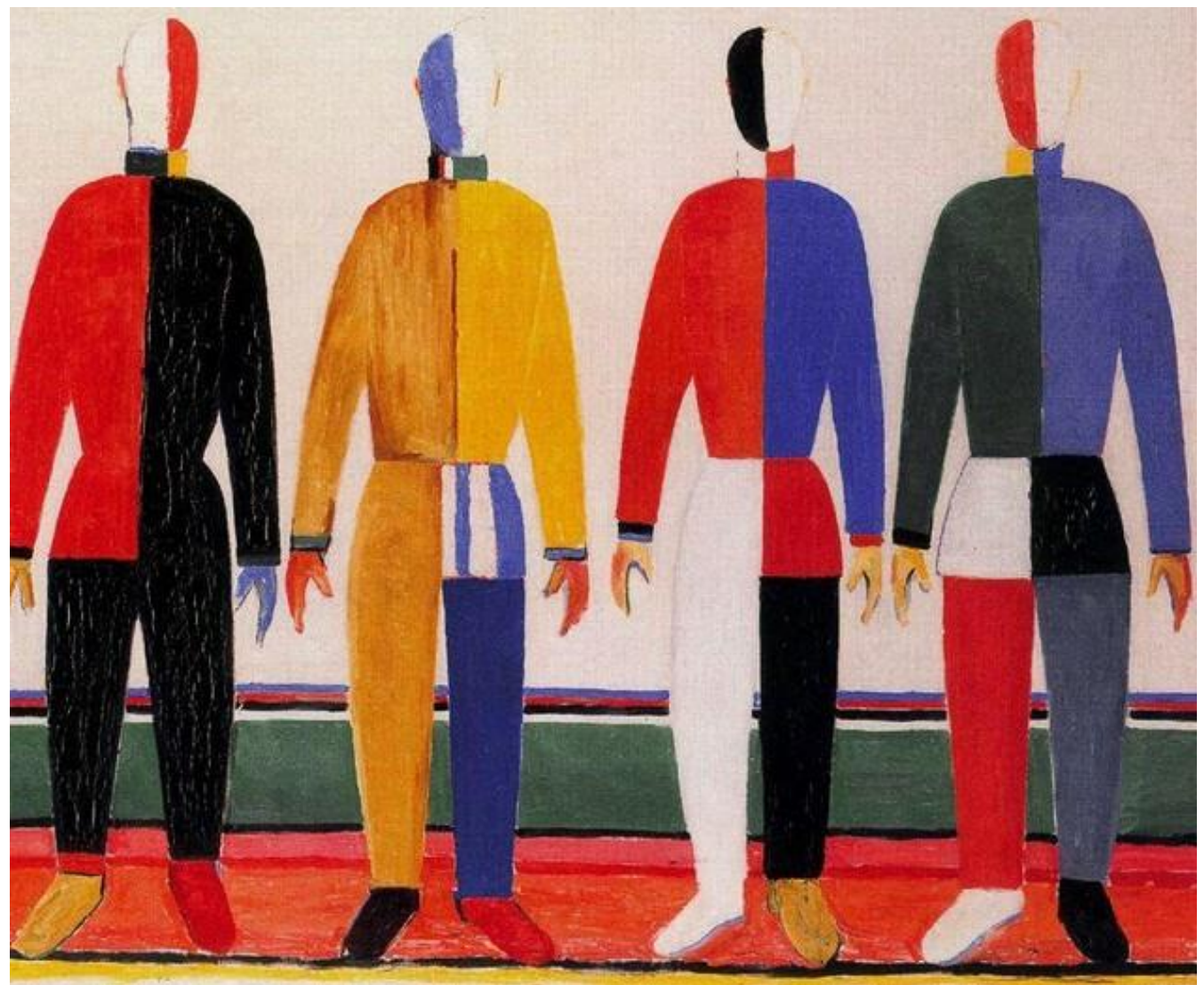

Fonte: Harrison, Frascina e Perry (1998). Óleo sobre tela. 142x164cm. Museu do Estatado Russo, São Petersburgo. 
Há certa imaterialidade e leveza nessas obras. Essa imaterialidade acompanha o artista desde o início do Suprematismo. No verso de Esportistas (1930-1932), o artista escreveu: "Suprematismo com silhuetas de esportistas". Essa combinação entre imagem e descrição confirma o interesse consciente de Maliévitch pela elaboração de um novo conceito de Suprematismo. É interessante observar que "os personagens" continuam sendo os mesmos de décadas anteriores. $O$ esportista já havia sido utilizado na ópera Vitória sobre o Sol. Nas fases que antecederam o Suprematismo, o artista pintava trabalhadores do campo, sempre com aspecto pesado e sofrido. Quase duas décadas passaram, com períodos de guerra, revolução, mudanças no setor industrial, e o artista retornou a temas do passado. Talvez, mesmo depois de tanto crescimento na cidade, a vida do campo continuasse tão limitada quanto antes.

Poderíamos tentar justificar essas conclusões com elementos da pintura Para a colheita II (Figura 62), em que o artista, no final da década de 1920, ainda utiliza conhecimentos já adquiridos anteriormente no cubo-futurismo, com a mesma temática. 
Figura 62 - K. Maliévitch: Para a colheita II - 1928-1929

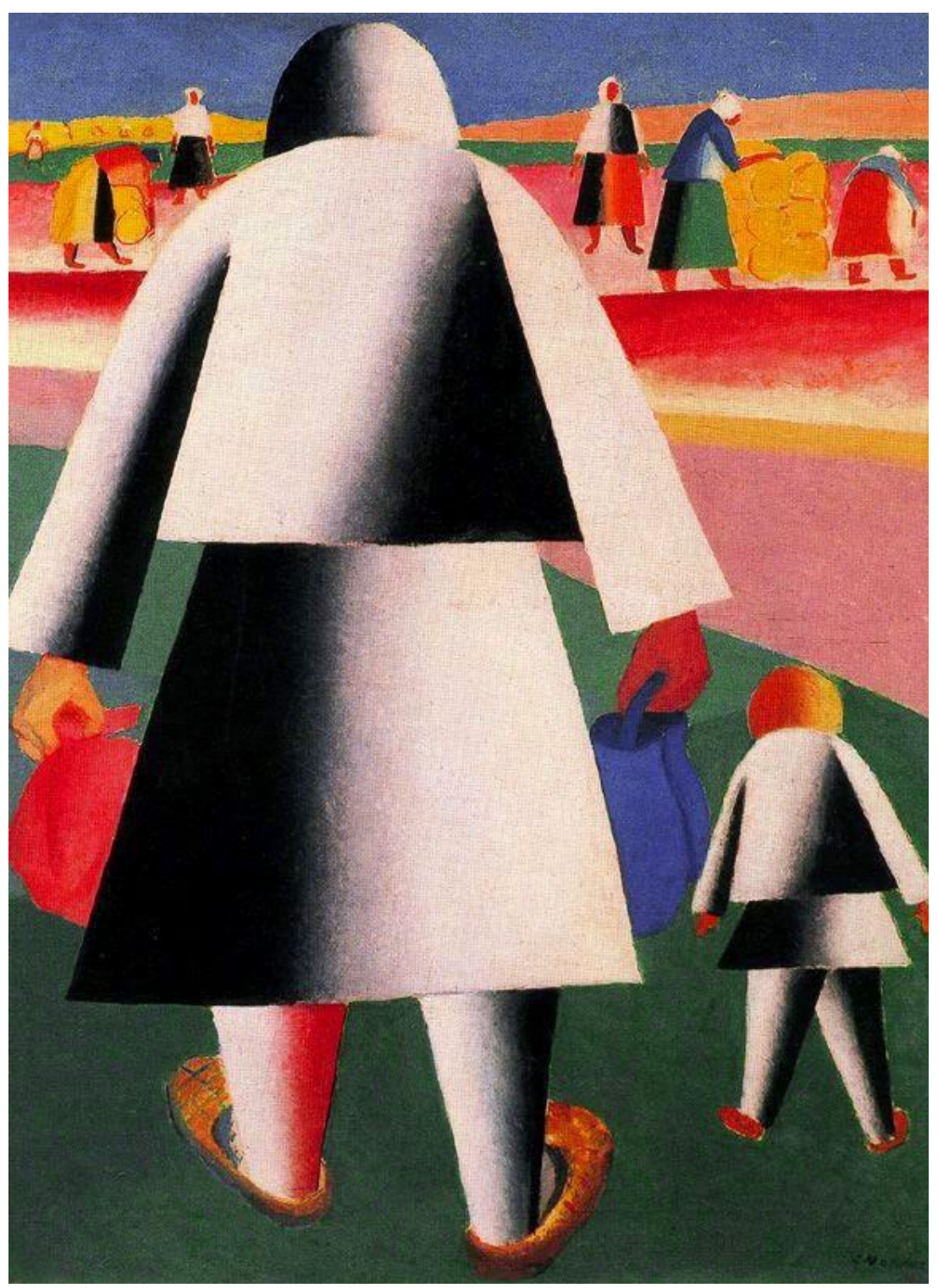

Fonte: Souter.

Na obra Autorretrato (Figura 63), notamos o retorno de um gesto sacralizado, de acordo com a tradição dos ícones, e da pintura renascentista devido a frontalidade assemelhando-se ao divino (Figura 64). Na pintura A operária (Figura 65), notamos certa imaterialidade nas roupas, construídas com cores primárias; os braços e o corpo são robustos; a feminilidade é perceptível apenas por pequenos detalhes, pois a figura assemelha-se à robustez masculina, na imagem seguinte observamos o artista em seu ateliê pintando Garota com bastão Vermelho (Figura 66). Notamos ainda que a assinatura do Autorretrato é representada por um quadrado. Podemos entender que, de acordo com a visão do artista, o Suprematismo continua. 
Figura 63 - K. Maliévitch: Autorretrato - 1933

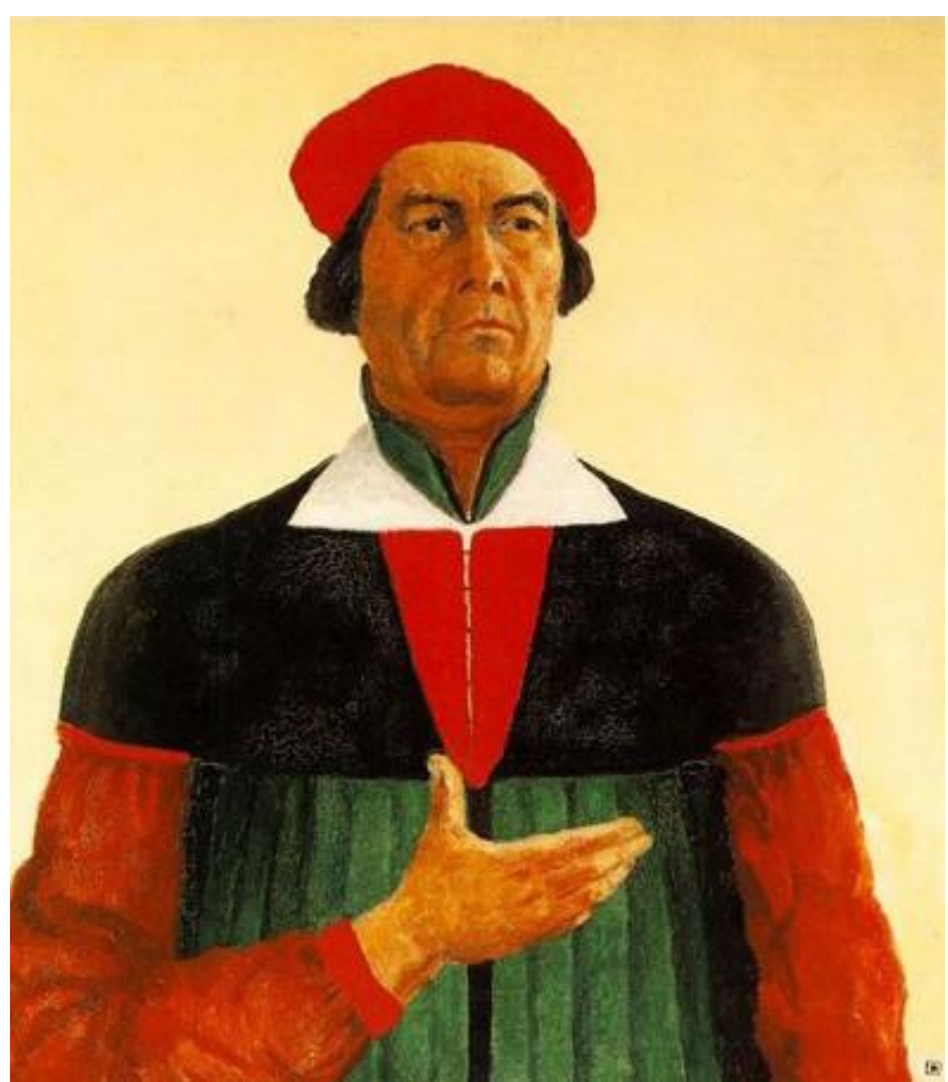

Fonte: Aguilar (2002). Óleo sobre tela. 73x66cm. Museu do Estado Russo, São Petersburgo.

Figura 64 - Albrecht Dürer: Autorretrato com casaco de Pele - 1500

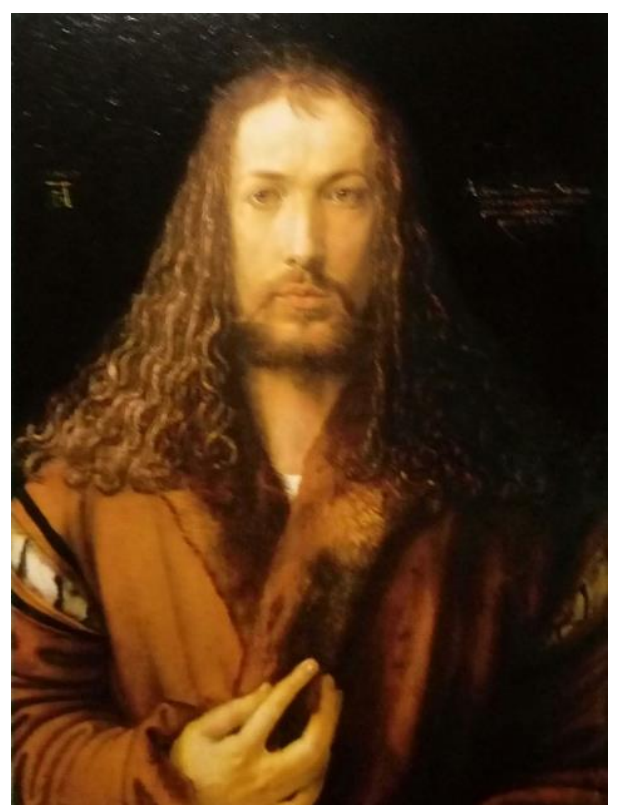

Fonte: Simmen e Kohlhoff (2001). Madeira. 67x49cm. Alte Pinakothek, Munique. 
Figura 65 - K. Maliévitch: A operária - 1933

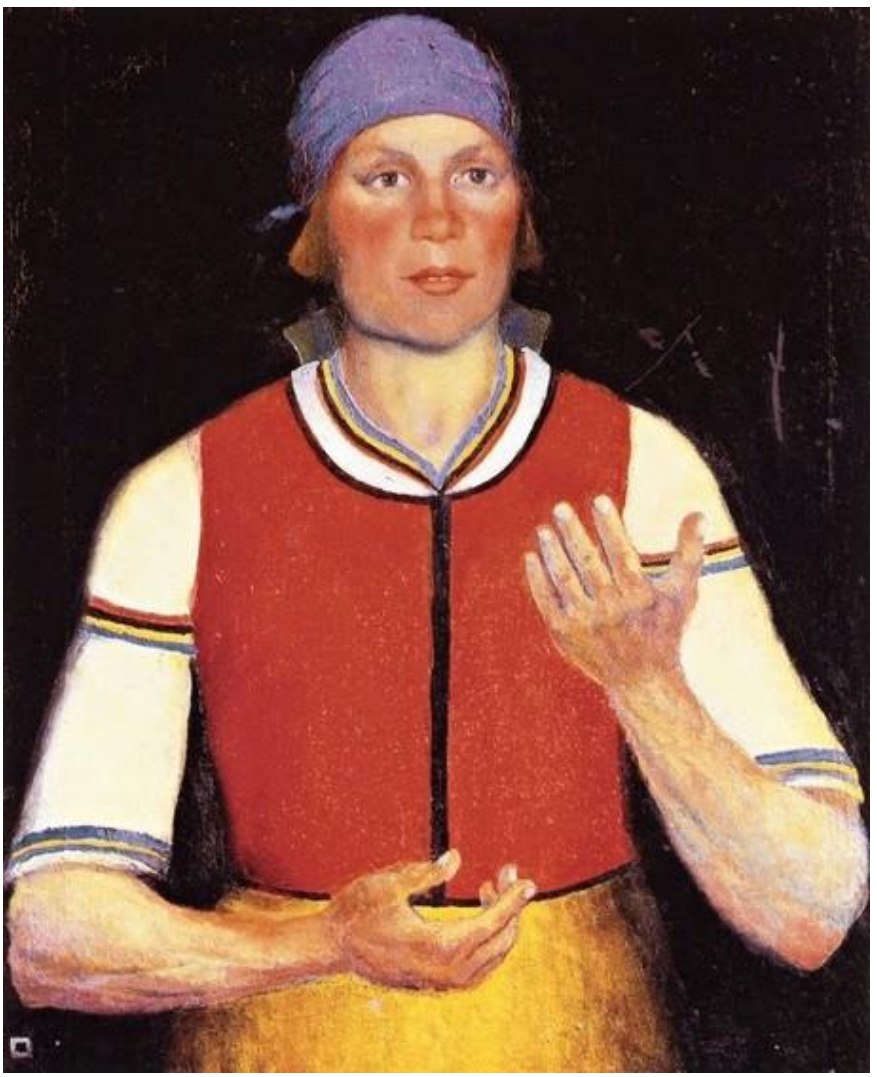

Fonte: Bermejo (1995)

Figura 66 - K. Maliévitch: Garota com Bastão Vermelho - 1932

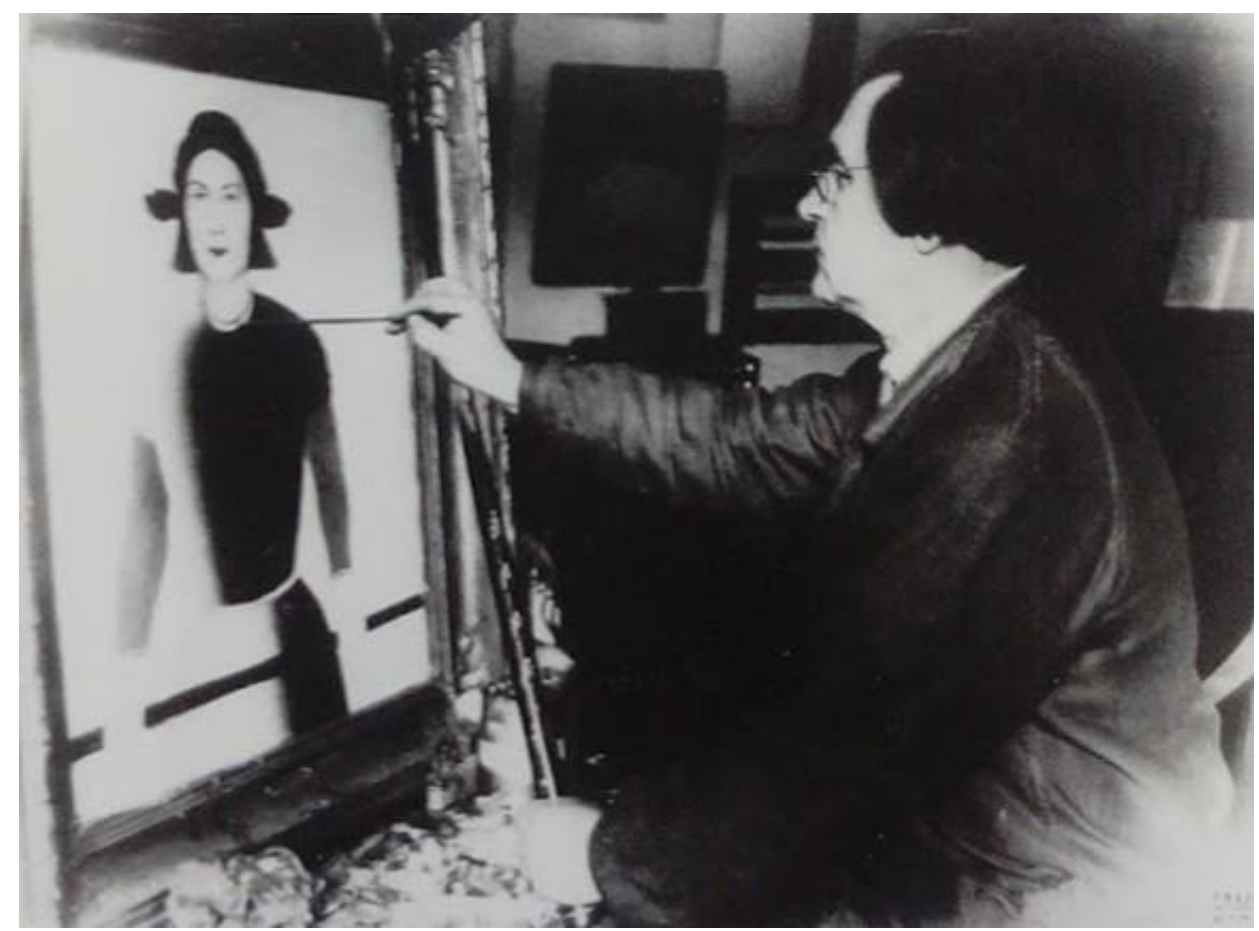

Fonte: Drutt (2003). 
Apesar do silêncio, praticamente imposto aos artistas devido às condições e obrigações com o estado, Maliévitch continuou atuando como pintor, mas não se pode negar o estranhamento que sua volta à pintura figurativa tenha causado.

Sobre esse aspecto: "Cumprimentamos o homem valente que se lançou ao abismo a fim de ressuscitar os mortos sob uma nova forma. Se a linha pictórica desceu regularmente... 6, 5, 4, 3, 2, 1, até 0 , no outro extremo começa uma linha nova $0,1,2,3,4,5, \ldots$,.' (LISSITZKY, 1922 apud BERMEJO, 1995, p. 46).

Nas fases anteriores do artista, a face foi representada de modo a não identificar o rosto do indivíduo, representando um indivíduo daquele momento no universo. No Suprematismo, as formas são os próprios ícones, os ícones modernos. No Suprematismo Figurativo, notamos as semelhanças das figuras humanas com ícones, o homem de uma nova época.

Conclui-se essa análise com a analogia feita no livro da exposição 500 Anos de Arte Russa (Figura 67 e 68).

Figura 67 - K. Maliévitch: Cabeça de camponês - c. 1928-1929

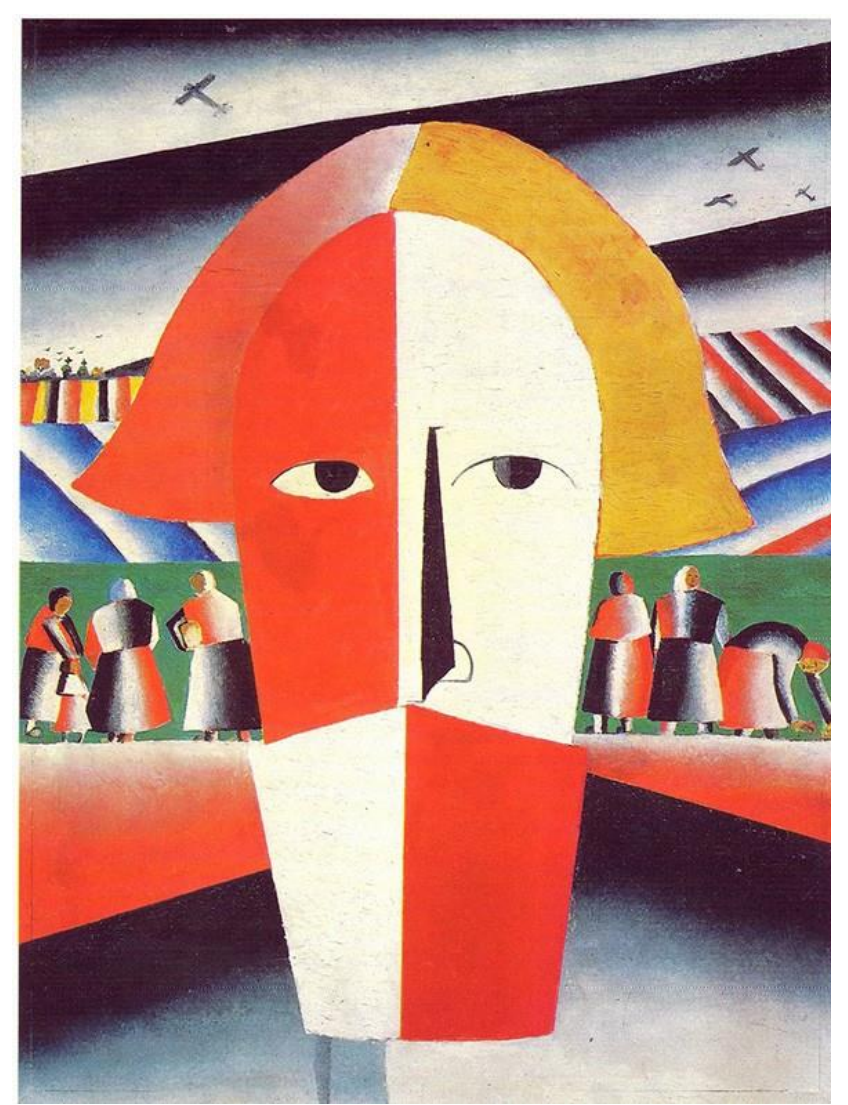

Fonte: Aguilar (2002). Óleo sobre madeira. 72×54cm. 


\section{Figura 68 - Salvador Todo Poderoso}

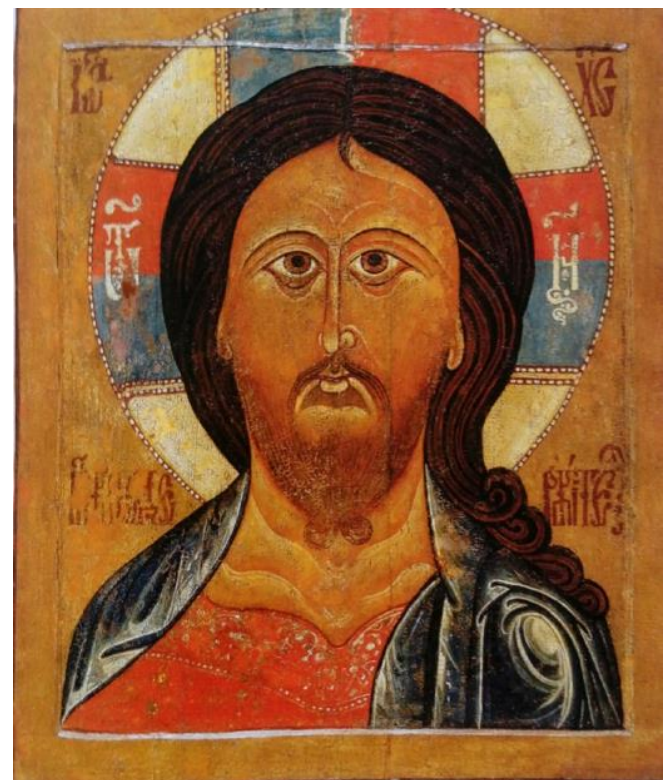

Fonte: Aguilar (2002). Têmpera sobre madeira. 89,2x76,5x3,5. Original da Igreja da Proteção da Mãe de Deus, da vila Liadini, Kargóspolsk, região de Arkhânguelsk.

Sobre a obra A Cavalaria Vermelha (Figura 69), há comentários divergentes. Alguns críticos acreditam que o artista cedeu às diretrizes artísticas reacionárias da época, imperantes na União Soviética, enquanto outros acreditam que a obra utiliza elementos figurativos, que estiveram presentes desde o início de sua carreira, relacionando o simbolismo da cavalaria vermelha a uma dimensão poética e não política.

\section{Figura 69- K. Maliévitch: A Cavalaria Vermelha - 1928-1932}

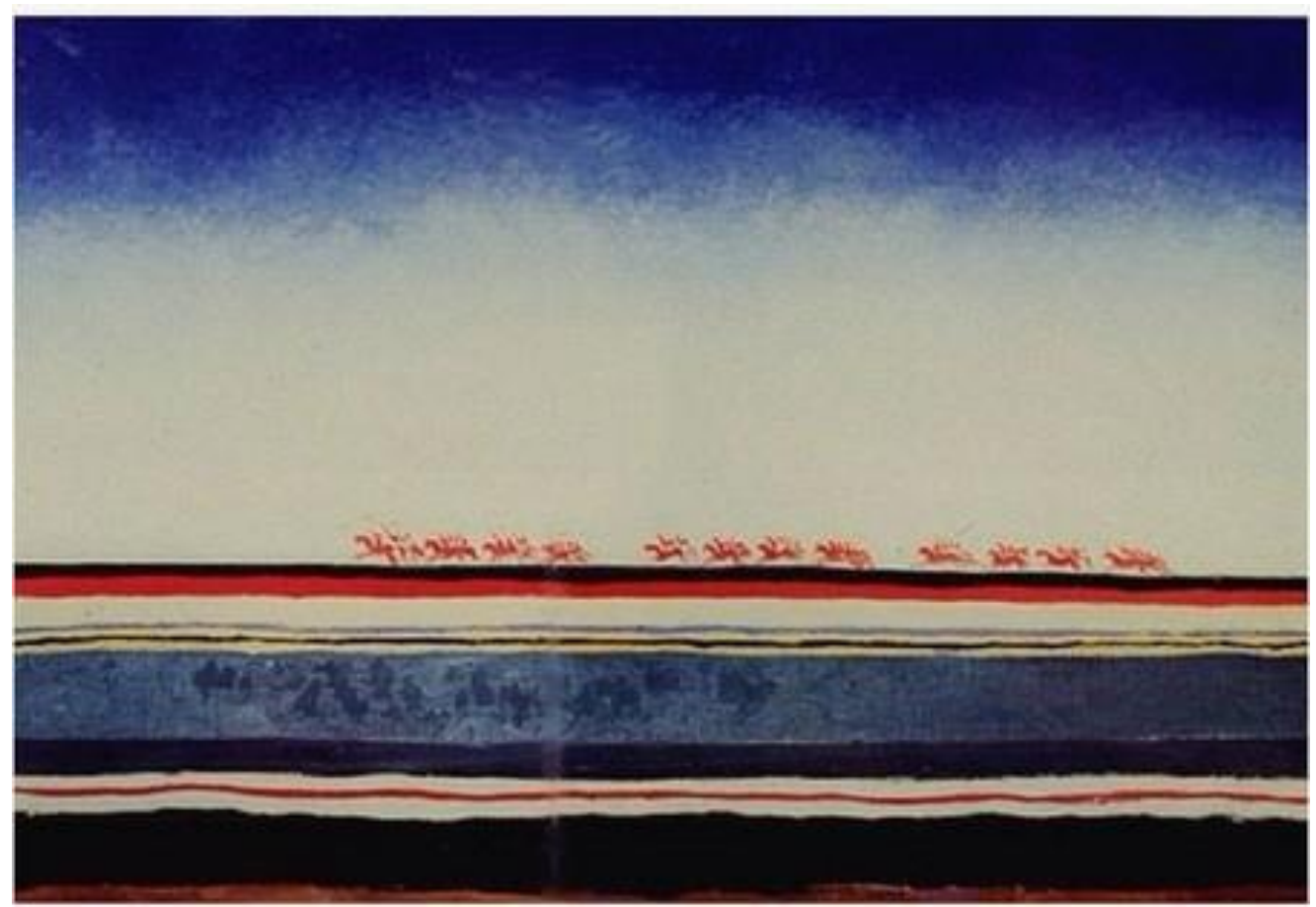

Fonte: Simmen e Kohlhoff, 2001. Óleo sobre tela. 91x140cm. Museu do Estado Russo, São Petersburgo. 
De 1918 até o fim de sua vida, em 1935, além do estudo sobre os Arquitéctonos $^{15}$, Maliévitch se dedicou ao desenvolvimento de seu método pedagógico e escreveu tratados sobre o movimento moderno. Em 1935, o artista morreu de câncer e foi cremado num caixão decorado com desenhos suprematistas executados por ele mesmo (Figura 70).

\section{Figura 70 - Maliévitch no leito de morte}

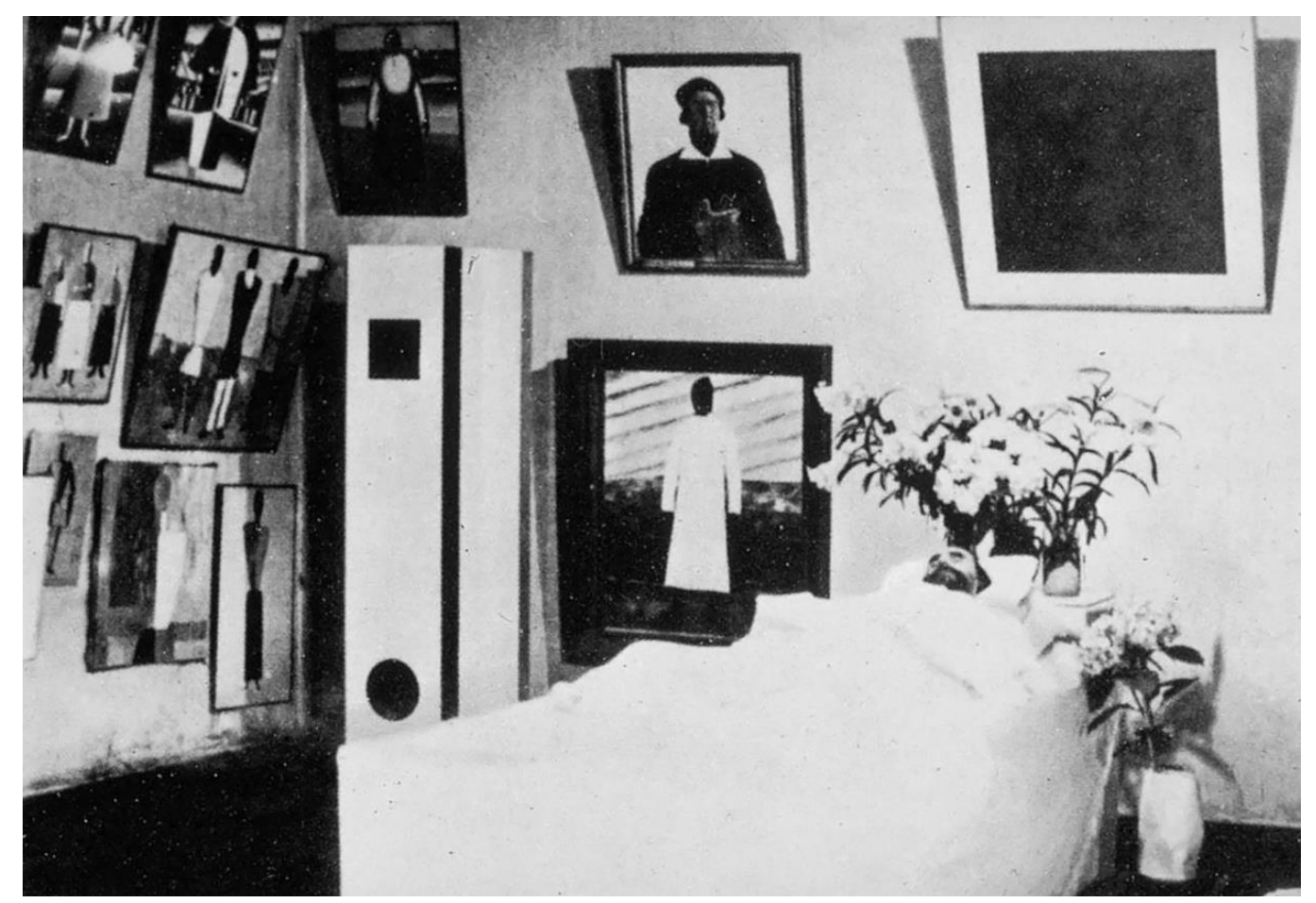

Fonte: Centro Cultural Banco do Brasil (2002).

Estudando a arte abstrata, pode-se notar a infinitude da arte. Depois de séculos de caminhos artísticos, percebemos que a criação não para, seja ela humana, seja divina. Em cada obra ou Movimento artístico, observa-se que tudo acontece a seu tempo. Depois de um esgotamento mimético vivido por décadas, foram apresentadas propostas artísticas abstratas. Que sentido poderia fazer para um indivíduo que viveu no Renascimento uma obra como o Quadrado Preto? E hoje, qual seria o sentido dessa pintura? Depois do trabalho artístico de Maliévitch, que foi e continua sendo considerado como um dos pais da abstração e da busca por extremos, seria natural concluir que não poderiam existir outras inovações artísticas que também chegassem a outro extremo. Ledo engano. Rothko apresentou uma pintura intimista, talvez por uma intuição divina, só para provar que a criação realmente é infinita, assim como o criador.

\footnotetext{
${ }^{15}$ Modelos volumétricos com inesgotáveis possibilidades plásticas (AGUILAR, 2002, p. 425).
} 


\section{UM OLHAR PÓS-SUPREMATISTA: ASPECTOS DA OBRA DE MARK ROTHKO}

Lançar um olhar Maliévitchniano sobre a obra de Mark Rothko deve-se à imensa importância da percepção de questões de imaterialidade que suas pinturas abarcam. Não temos a intenção de analisar a extensa obra de Mark Rothko, ou seja, a importância do sensível em relação ao inteligível, do metafísico ao pictórico, características neoplatônicas ${ }^{16}$ presentes, também, em Maliévitch.

Sobre essa ideia:

Eles valorizam a expressão mais do que a perfeição, a vitalidade mais do que o acabamento, a flutuação mais do que o repouso, o desconhecido mais do que o conhecido, o velado mais do que o claro, o individual mais do que o social, e o interior mais do que o exterior (SEITZ apud BAAL-TESHUVA, 2003, p. 10).

Maliévitch e Rothko são artistas russos. Enquanto Maliévitch atuou nas proximidades de seu território natal, Rothko imigrou para os Estados Unidos ainda criança e foi um dos artistas expressionistas abstratos, integrantes da Escola de Nova Iorque.

Na década de 1920, os Estados Unidos passavam por um isolacionismo cultural e econômico, como consequência de suas relações políticas. A Rússia também havia passado por um período semelhante devido à Primeira Guerra e à Revolução de 1917. As instituições de arte americanas, antes de 1945, demonstravam pouco interesse pela arte local e somente depois da Primeira Guerra essa arte americana começou a ganhar território devido à inauguração de importantes galerias, entre elas: The Intimate Gallery e An American Place. A Escola de Nova Iorque começou a ter destaque com a exposição no Museu de Arte Moderna (MoMA), em 1952, conhecida como Quinze Americanos.

[...] a inauguração dessas galerias e seu crescimento ao longo dos anos que se seguiram ao Armory Show, além da criação de um mercado e de um público para o Modernismo tanto europeu quanto americano demonstravam que a arte dos Estados Unidos não estava necessariamente limitada às suas formas vernáculas predominantes nos anos 30 (HARRISON et al., 1998, p. 35).

$\mathrm{Na}$ segunda metade do século XX, a abstração ainda era tida por muitos como um sintoma de decadência cultural. Clement Greenberg, um dos principais críticos de arte da época, era defensor da abstração.

A arte é rigorosamente uma questão de experiência, e não de princípios; na arte o que conta em primeira e última estância é a qualidade [...] Ninguém ainda foi

\footnotetext{
16 Neoplatônico: o neoplatonismo é geralmente uma filosofia metafísica e epistemológica (disponível em:
} <https://pt.wikipedia.org/wiki/Neoplatonismo>. Acesso em 23 jan. 2019). 
capaz de demonstrar que o representativo, como tal, aumenta ou diminui o mérito de um quadro ou de uma estátua (GREENBERG, 1961 apud CHIPP, 1999, p. 588).

A pintura social-realista também estava em declínio por estar associada a ideais comunistas russos, mas a opção pela abstração permitiu Rothko libertar-se dos contextos opressivos políticos e ideológicos. O pintor considerava que o nacionalismo artístico era nocivo ao desenvolvimento da arte.

Com relação a esse aspecto:

Se pudermos recuperar a verdadeira política daquele momento, do final dos anos 30 ao final dos 40, e relacionar a cultura e a política da Depressão à dos primórdios da Guerra Fria, talvez possamos entender por que a idéia e o sonho de uma arte desvinculada das realidades políticas e sociais passou a exercer tanta atração em artistas que antes haviam estado comprometidos com a transformação da sociedade americana (HARRISON et al., 1998, p. 35).

A escala das pinturas dos expressionistas abstratos demonstrou uma nova forma de organização pictórica, comparadas à dimensão de um mural. Esta "nova dimensão" foi definida por Greenberg como: pintura à americana. Outra caraterística presente nesses artistas é a "composição total” (all over), ou seja, composições que não têm um foco único. (HARRISON et al., 1998, p. 50).

Nos estudos de Maliévitch sobre os Novos Sistemas da Arte, o artista considerou a importância que o Cubismo e o Futurismo exerceram para a formação do pensamento suprematista. No entanto, para Greenberg, o expressionismo abstrato foi uma decorrência influenciada pelo cubismo europeu. O crítico não considerou que o percurso artístico de Maliévitch, pictórico ou conceitual, pudesse ter influenciado os artistas na segunda fase da abstração: “[...] Na verdade, seu julgamento mais direto sobre Malevich, publicado em 1942, é que, embora a obra dele tenha 'valor documental', é 'escassa em resultados estéticos' (HARRISON; FRASCINA; PERRY, 1998, p. 217).

Em relação a Rothko, sua carreira artística pode ser dividida em quatro períodos: Realista, de 1924 a 1940; Surrealista, de 1940 a 1946; Fase de transição, de 1946 a 1949; Classicismo, de 1949 a 1970. Essa última fase é a mais relevante para este estudo.

Rothko tinha a necessidade de expressar, em suas obras, o drama humano, ou seja, sua arte não era uma representação, mas uma revelação profética. A busca pelo espiritual e sensível não estaria ligada às técnicas de pintura, nem a algum tipo de virtuosismo, mas a um sentimento de apreensão da essência, interioridade e expressão de espontaneidade da forma artística. 
[...] Com Rothko, chega-se à convicção de que a pintura e a tinta têm a ver com emoção, enquanto que para os outros tinta é apenas tinta... A sua pincelada repercute-se em todo o sentir que a pintura provoca [...] (MARDEN, 1927 apud BAAL-TESHUVA, 2003, p. 24).

Rothko também se interessava pela educação e espontaneidade infantil. Para o artista, as crianças deveriam começar um trabalho artístico pela cor, pois o fato de elas iniciarem o trabalho pelo desenho já seria um aspecto limitante.

Embora Maliévitch e Rothko fossem artistas e filósofos, os respectivos processos criativos foram totalmente diferentes. Para Maliévitch, antes da existência da obra, havia um conceito definido, um manifesto, e o resultado pictórico era consequência da proposta conceitual. Nota-se essa característica em todos os Quadrados, por exemplo. O artista tinha o controle do resultado final da pintura. Em Rothko, a pintura iniciava-se intuitivamente, e, na sequência do trabalho, no ato de pintar, a própria pintura decidiria seus passos seguintes. É como se a pintura fosse amadurecendo em si mesma.

Sobre esse aspecto:

Pictures must be miraculous: the instant one is completed, the intimacy between the creation and the creator is ended. He is an outsider. The picture must be for him, as for anyone experiencing it later, a revelation, an unexpected and unprecedented resolution of an eternally familiar need ${ }^{17}$ (ADORNO et al. 1947).

Na busca por inspirações, o pintor visitava museus, encantando-se com algumas obras, em especial com A Sala Vermelha, de Matisse. Rothko dizia que, ao olhar para a obra, "tornamonos a própria cor". Como sabemos, Matisse construía seus quadros com a cor através de campos harmônicos. O artista criava o espaço e suas relações composicionais que resultariam em formas figurativas. Rothko também pintava suas telas com grande força composicional, com "campos coloridos" que objetivavam levar uma introspecção entre obra e indivíduo, sem qualquer imagem familiar. A pintura Homenagem a Matisse, 1948 (Figura 71), foi o modo que o artista encontrou para demonstrar seu encantamento pelo artista.

\footnotetext{
17 “As imagens devem ser miraculosas: no instante da conclusão [da obra], a intimidade entre a criação e o criador é encerrada. Ele passa a ser um estranho. A imagem deve ser para ele como para qualquer um que a visualize depois, uma revelação, uma resolução inesperada e sem precedentes familiares".
} 
Figura 71 - Homenagem a Matisse - 1948

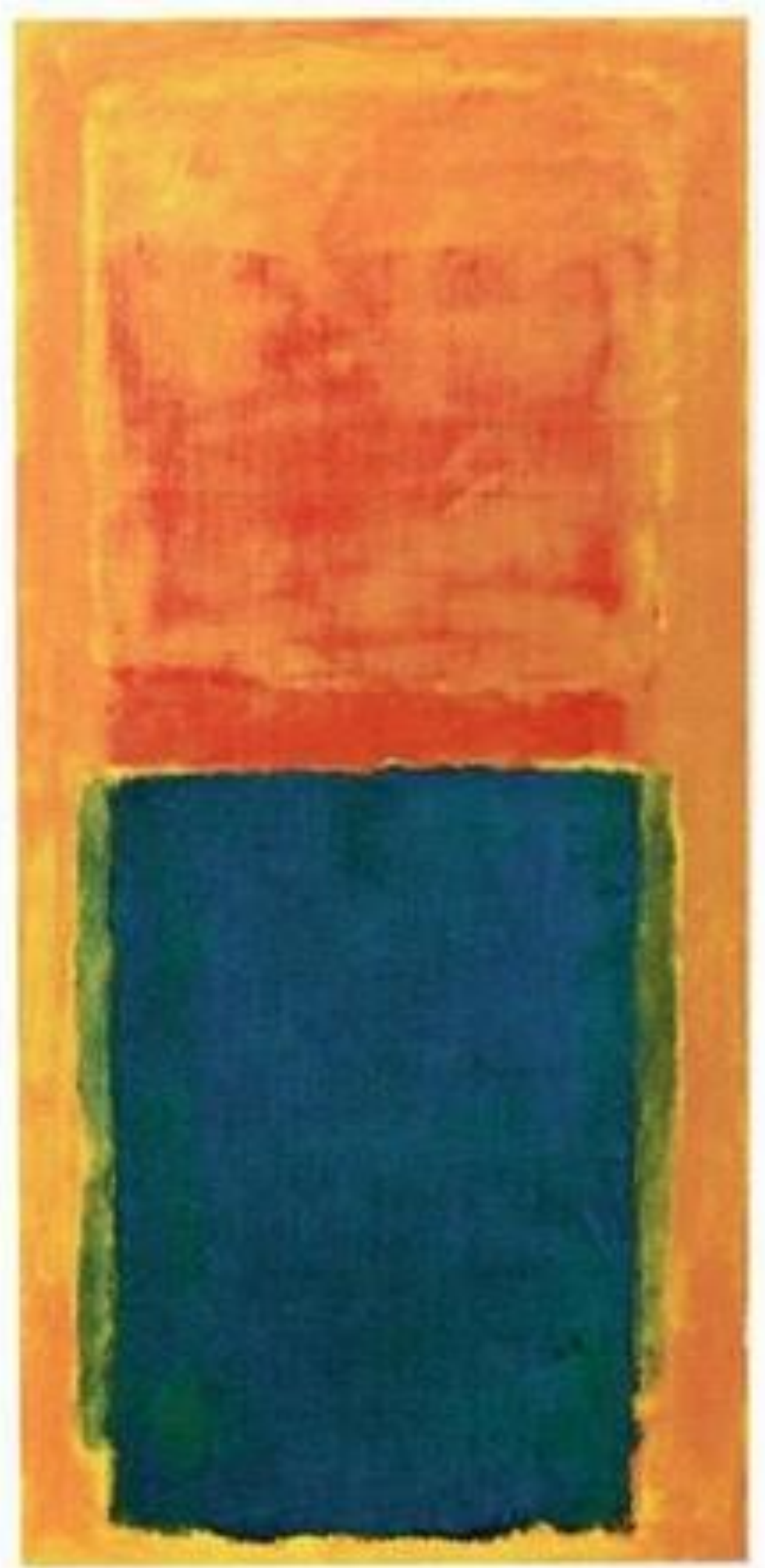

Fonte: Baal-Teshuva (2003). Óleo sobre tela. 268,3x129,5cm. Coleção The Edward R. Broida Trust. 
Rothko defendia a eliminação de todos os obstáculos entre o pintor e a pintura e também entre a ideia e o observador, ansiando por experiências transcendentais. Resistia a tentativas de interpretação. Para o artista, a obra deveria falar por si só, uma experiência entre pintura e indivíduo. Nenhum conjunto de notas pode explicar as nossas pinturas [...] A explicação tem de advir de uma experiência consumada entre pintura e observador" (BAAL-TESHUVA, 2003, p. 7).

A busca por uma arte intuitiva e o prevalecimento do espírito sobre o intelecto são características predominantes entre artistas que buscavam dar materialidade ao sensível. Assim como Maliévitch, Rothko também aboliu a narração em seus quadros. O artista escreveu: "The familiar identity of things has to be pulverized in order to destroy the finite associations with which our society increasingly enshrouds every aspect of our environment"18 (ADORNO et al., 1947).

A partir de 1947, as pinturas de Rothko foram chamadas de "pinturas de campo de cor". Nas obras $N^{o} 61$ (Figura 72), Açafrão (Figura 73), $N^{o} 8$ (Figura 74), as vibrações de campos de cores em áreas determinadas criam pulsações, flutuações e derramamentos de luminosidades. Um detalhe importante nas obras de Rothko é que o artista fazia questão de acompanhar as instalações de suas obras em galerias e museus para controlar a iluminação e manter o ar de mistério. Podemos notas que a flutuação em Rothko difere da de Maliévitch. Na segunda fase do Suprematismo, em que formas aparecem soltas no espaço, há uma movimentação constante, como se fossem produzir diferentes composições sobre um fundo, um "cosmos de sentidos visuais".

Poderíamos inferir que o artista não controla o entendimento de sua obra pelo observador. Tanto em Maliévitch quanto em Rothko, poderíamos intuir que, para um maior discernimento sobre a dimensão física e espiritual de suas obras, o espectador precisaria de ter um olhar sensível para as questões da visualidade moderna e atual.

Merleau-Ponty diz que, quando um indivíduo acessa uma obra, ele também está acessando seu próprio ser (MERLEAU-PONTY, 2004). Além da forte presença da imaterialidade em Maliévitch e Rothko, podemos considerar esse modo de conhecimento de mundo outra característica fortemente encontrada na proposta pictórica de ambos.

"A minha arte não é abstrata, vive e respira" [...] Talvez tenham notado que na
minha pintura existem duas características: ou as superfícies são expansivas
e empurram para fora em todas as direcções, ou as suas superfícies contraem-se
e puxam para dentro em todas as direções. Entre estes dois pólos, encontrarão
tudo o que eu quero dizer" (BAAL-TESHUVA, 2003, p. 50).

18 "A identidade familiar das coisas tem que ser pulverizada a fim de destruir as associações finitas com as quais nossa sociedade cada vez mais encobre cada aspecto de nosso ambiente". 
Figura 72 - No 61 (Castanho e Azul) - 1953

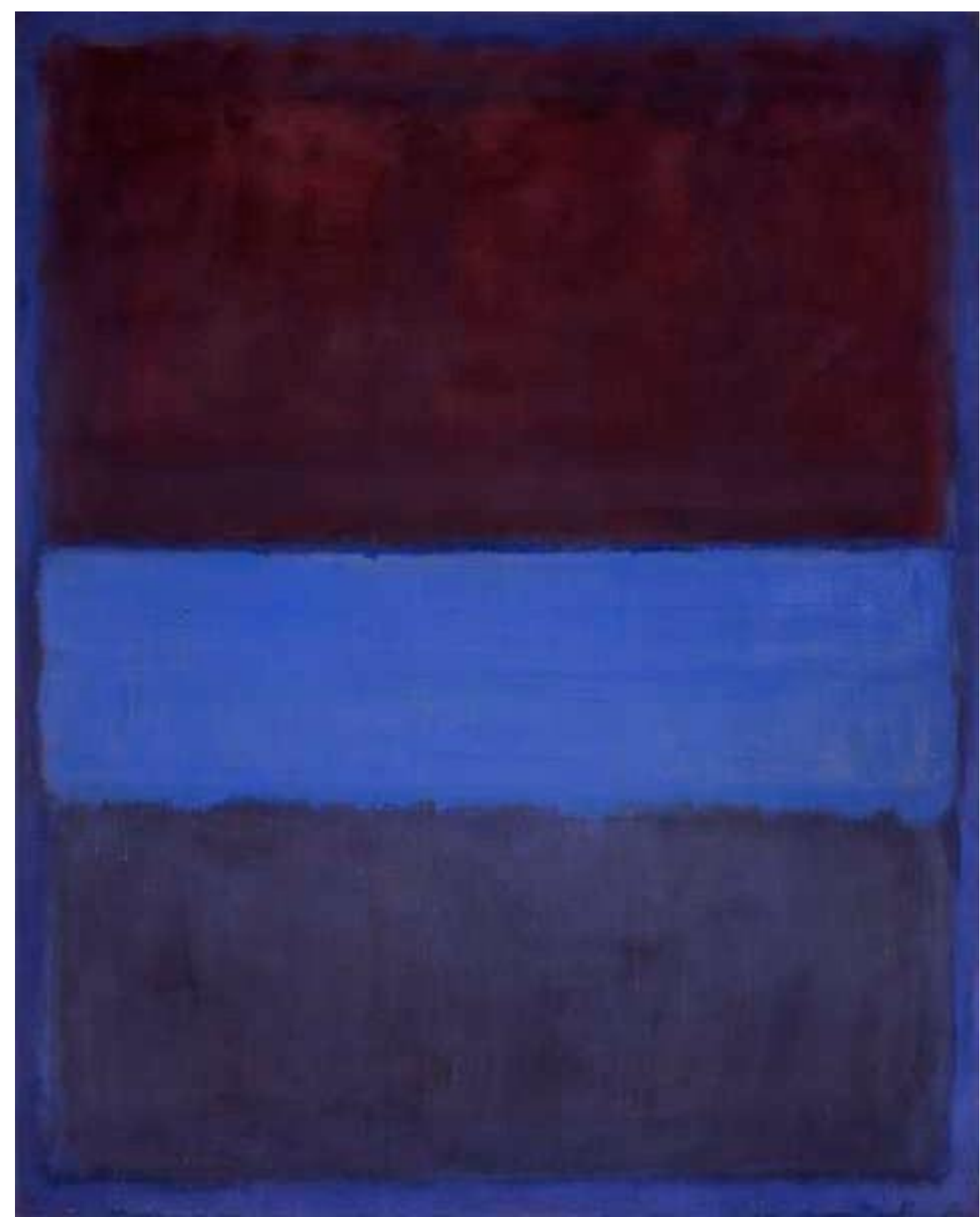

Fonte: Baal-Teshuva (2003). Óleo sobre Tela. 294x232,4cm. Los Angeles, Museu de Arte Contemporânea, Coleção Panza. 
Figura 73 - Açafrão - 1957

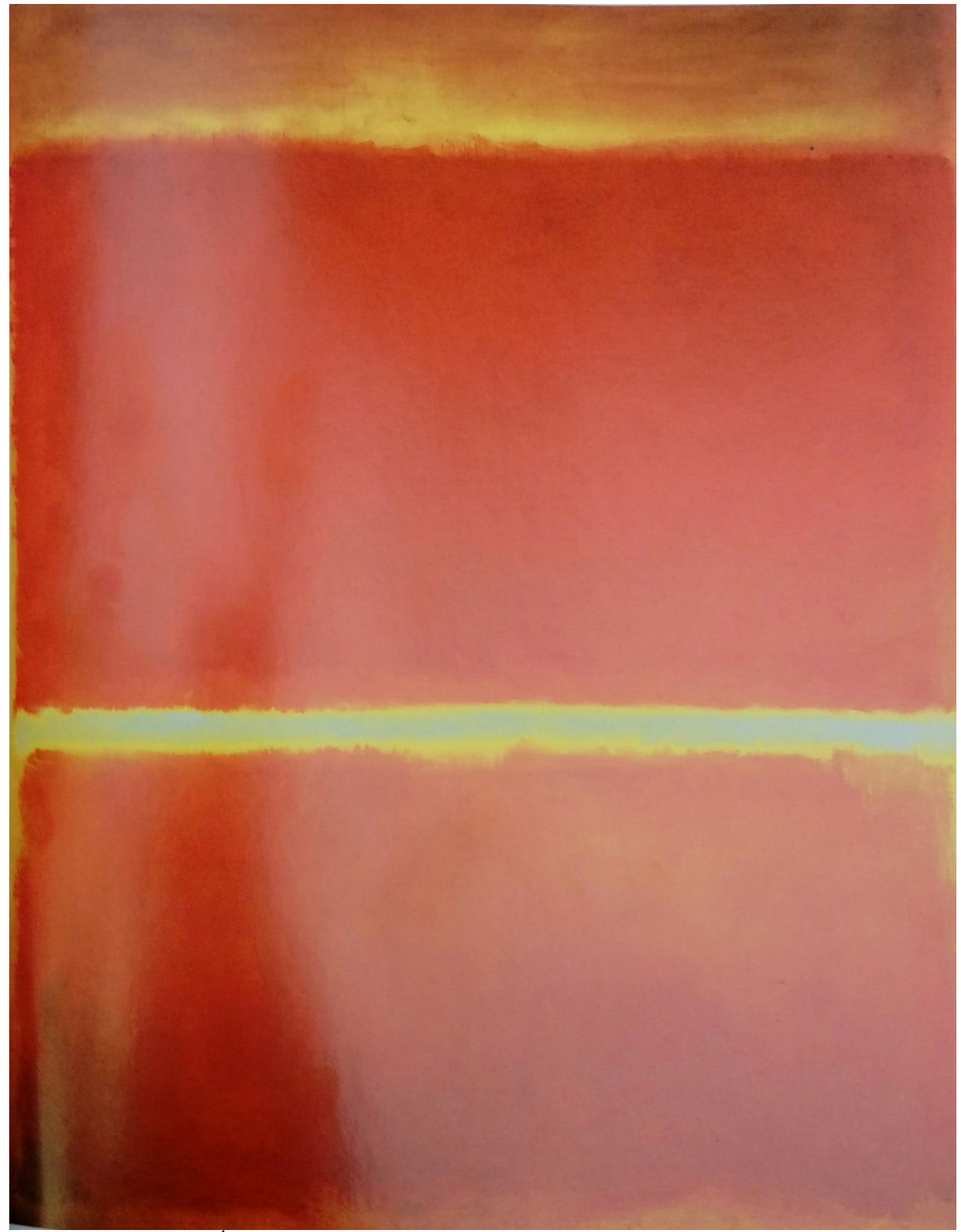

Fonte: Baal-Teshuva (2003). Óleo sobre Tela. 177x137cm. Liechtenstein, coleção privada. 
Figura $74-\mathbf{N}^{\circ} 8$ (Barra Branca) -1958

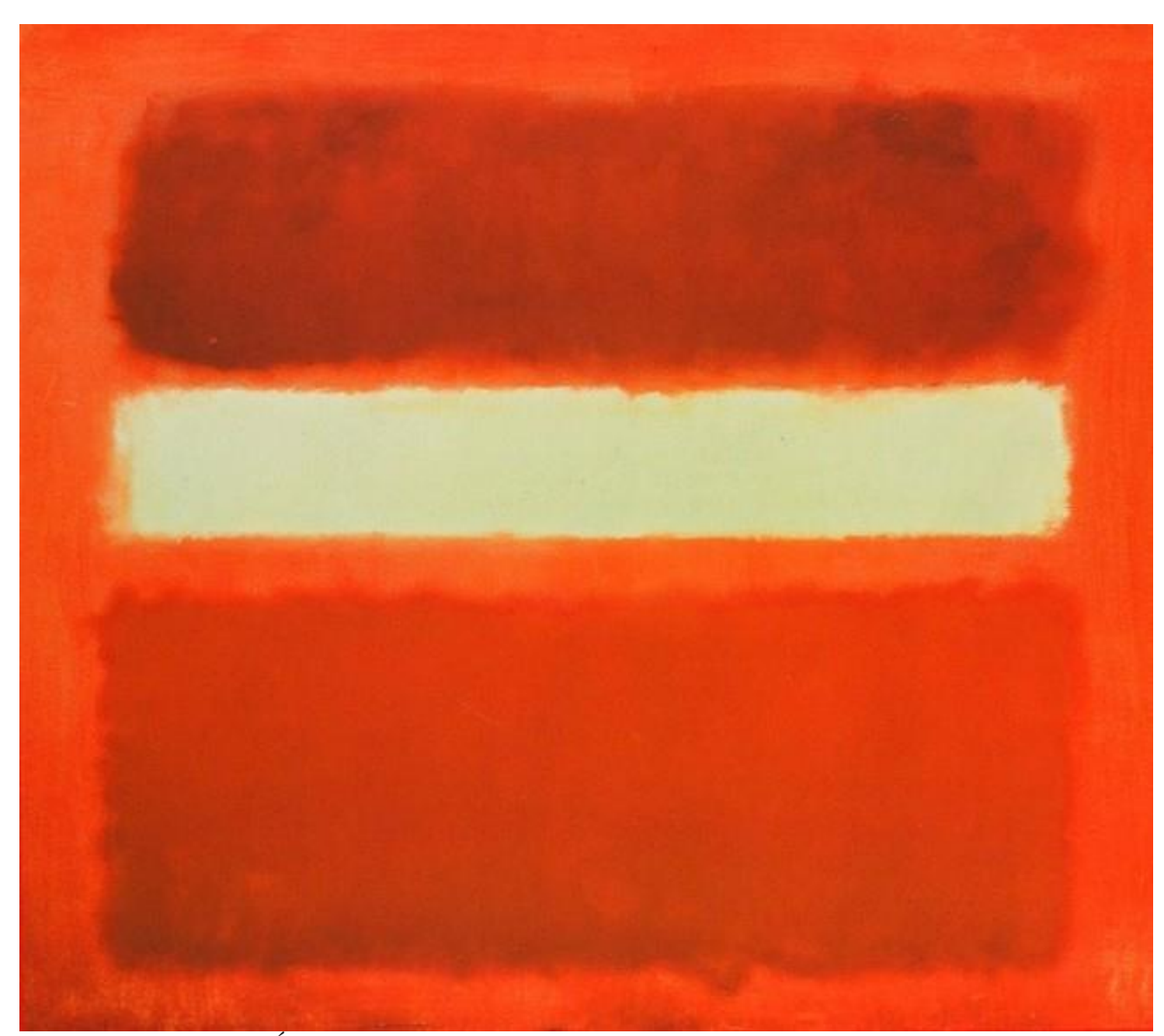

Fonte: Baal-Teshuva (2003). Óleo sobre tela. 207x232,4cm. Coleção particular.

Essa imersão entre o observador e a obra do artista teve como consequência, em 1964, um convite para pintar os murais da Capela Rothko, em Houston. O artista considerou que essa encomenda seria a maior experiência artística de sua carreira. Além das pinturas, o artista fez questão de acompanhar o projeto arquitetônico, e todos os detalhes da Capela foram validados por ele.

Sobre isso o artista escreveu ao casal que o convidou para o projeto: "A magnitude, a todos os níveis de experiência e significado da tarefa de que me incumbiram excedem o que até hoje concebi, e leva-me a que eu vá além do que alguma vez julguei ser capaz. Por isso, lhes agradeço" (BAAL-TESHUVA, 2003, p. 73).

Nos trabalhos da Capela Rothko (Figura 75), o artista optou por uma paleta de cores escuras com um acabamento quase monocromático e um alto nível de introspecção pictórica. Na profundidade da Capela, adentramos o espaço cósmico de espiritualidades e silêncio total. 
Em uma visita de Franz Meyer ao ateliê do artista:

[...] Depois, Rothko mostrou a primeira pintura para a capela, em grande formato, e que hoje está na parede sul da capela, entre as portas de entrada: um formato vertical estreito, em cujos quatro quintos superiores se impõe o preto intenso de um retângulo e o preto vinho tinto do fundo contra as margens [...] Era o primeiro trabalho da nova arte que eu via que me dava a sensação de estar a ter um vislumbre divino (MEYER, 1997, apud baal-teshuva, 2003, p. 74).

A Capela Rothko é um local ecumênico, com apresentações musicais, performances e discussões sobre variados temas. Na frente da Capela, do lado exterior, há uma escultura de Barnett Newman, Obelisco Quebrado (Figura 76), dedicada a Dr. Martin Luther King.

O artista morreu em 1970, antes da inauguração da Capela, em 1971.

\section{Figura 75 - Capela Rothko, vista interior}

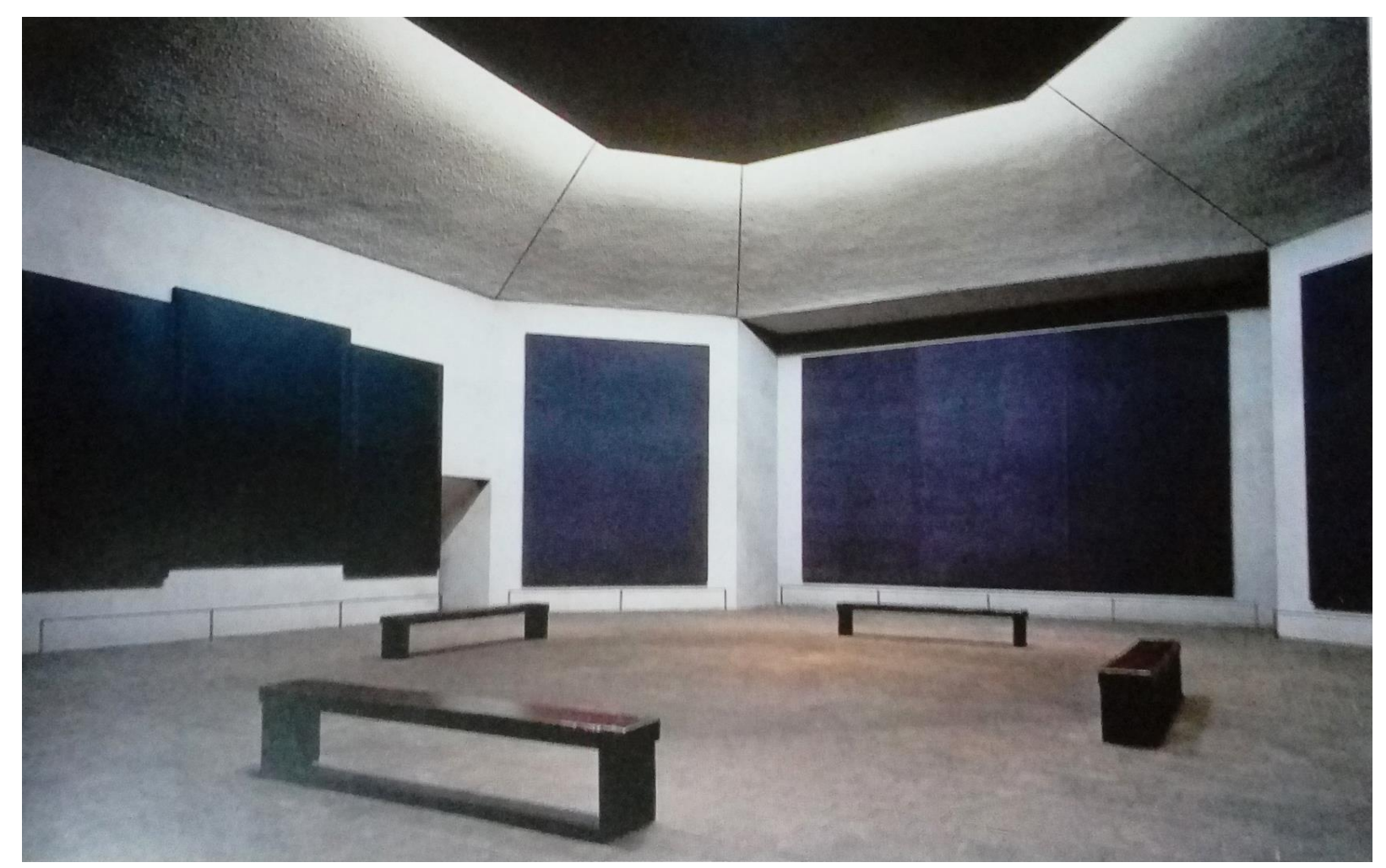

Fonte: Baal-Teshuva (2003) 


\section{Figura 76 - B. Newman - Obelisco Quebrado}

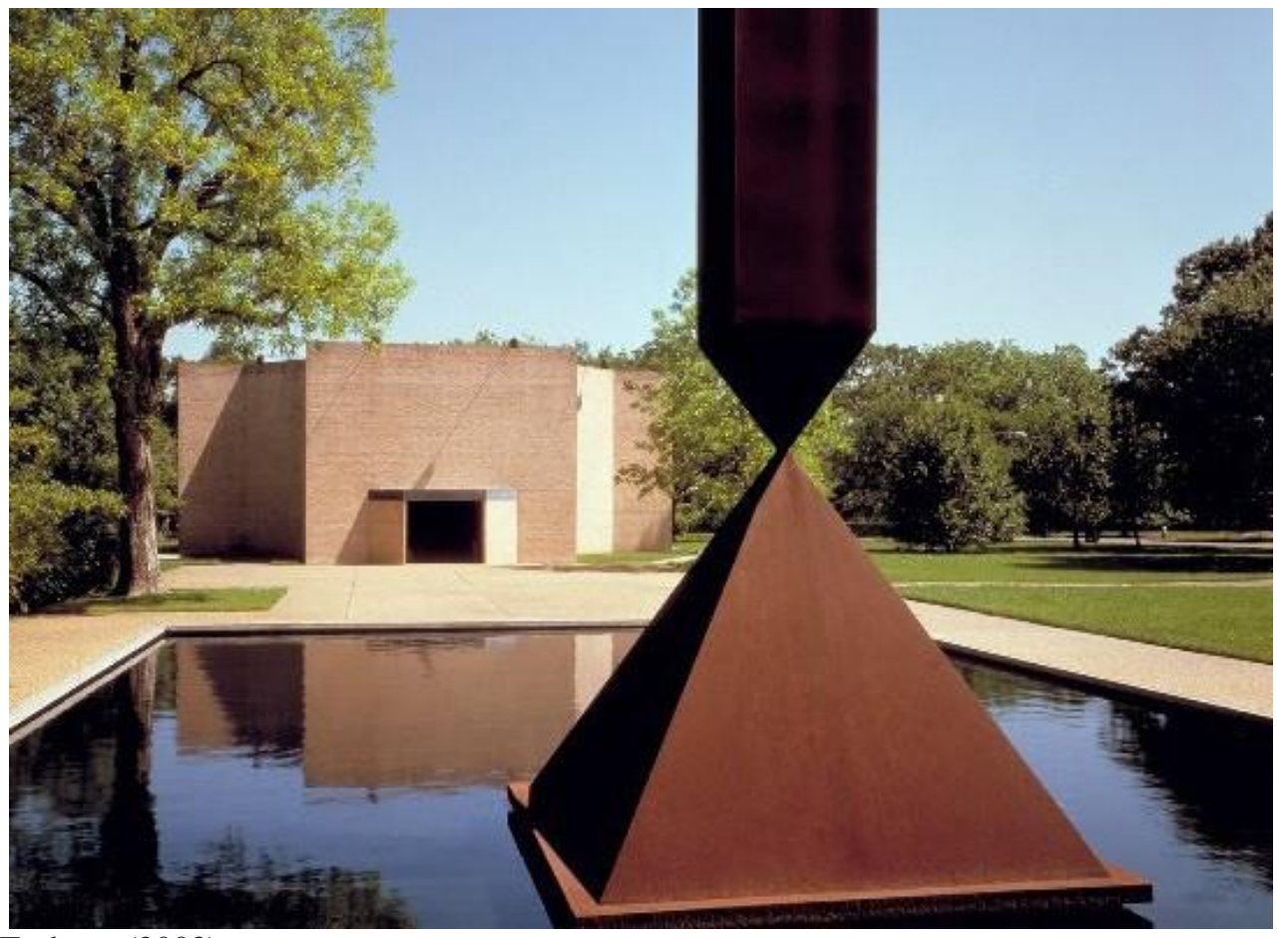

Fonte: Baal-Teshuva (2003)

A busca pela libertação da hostilidade no mundo foi um pensamento atuante nos trabalhos de Maliévitch e Rothko. A beleza facilmente encontrada nas pinturas naturalistas cedeu espaço à busca pela beleza do íntimo, não tocável, não visível, entretanto presente, levando os artistas a encontrarem novas formas de representar o sensível. A realidade, que nunca foi fácil, talvez tenha sido ainda mais difícil para esses dois artistas que viveram em períodos de guerra. Poderíamos dizer que, na obra de ambos, nota-se a necessidade de uma reconstrução emocional. De acordo com a Teoria do Elemento Adicional, de Maliévitch, seu trabalho estaria diretamente relacionado com o seu ambiente. Sendo assim, um artista da cidade desenvolveria obras com características urbanas, enquanto o artista do campo teria influências em sua obra relacionadas à natureza. Construindo um raciocínio embasado nesta Teoria, assim como o ambiente externo em que o artista vivesse influenciaria diretamente seus trabalhos, poderíamos intuir também que seu ambiente interno, ou seja, sua subjetividade afetaria o ambiente externo, no caso suas obras. Maliévitch e Rothko optaram pelo sentimento de amor, ao invés do sentimento de ódio e de competividade encontrados nas guerras e nas empresas devido ao crescimento industrial. Os artistas decidiram se influenciar pelo seu mundo interior. Na unicidade, já proposta por Maliévitch, pois não há como deixar de sentir o que se sente e pensar o que se pensa, a busca pelo uno do Quadrado Branco seria apenas consequência de seu sonho por um mundo inserido 
num êxtase harmônico. Rothko apostou na potencialidade do observador. No momento silencioso entre a obra do artista e o espectador, há uma intimidade sincrônica entre mundos: o mundo do pintor, da obra e do espectador, e aí encontrava-se o ápice da "reforma íntima" proposta pelo artista, em que corpos observam um ao outro. Esse encontro que se iniciava pelo visual passava pelo intelecto, pelos sentidos e adquiria uma incrível força sensível, obtida pela forma e da extrema e impactante força da cor, construída num campo físico. Talvez, no convite pictórico proposto por Rothko, o ato do espectador observar sua obra dar-lhe-ia acesso ao encontro do que há de mais profundo em seu próprio ser, mas, antes da subida deste mergulho, o observador se depararia com o Quadrado Preto, o "nada" formado com toda a potencialidade para um novo começo, como dizia Maliévitch. 


\section{CONSIDERAÇÕES FINAIS}

Um dos fatores marcantes desde o início do século XX foram os movimentos artísticos conhecidos como ismos, criados com a intenção de justificar e validar um ideal ou até mesmo uma nova poética visual. Se fosse o caso de escolhermos somente uma palavra para essa época, seria inovação, um período em que a arte passou a exigir de si própria autonomia e liberdade. O mundo estava mudando, mas, na verdade, o mundo nunca parou. Para nós, indivíduos desses séculos (XX e XXI), é natural perceber ou até mesmo sentir com mais proximidade algumas das consequências dos fatos dos últimos 50 ou 100 anos.

Em um momento em que a arte parou de responder às exigências do clero e da nobreza, para falar mais sobre a vida e seus novos valores, na Rússia, no início do século XX, colecionadores de arte proporcionaram mostras da arte europeia para o público local. Foi um período de grande intensidade cultural. Os artistas puderam conhecer obras da vanguarda europeia que tanto os influenciariam. Maliévitch, com o ideal de um mundo melhor, trouxe à tona uma proposta com novos valores de juízo. O sentimento estaria acima de qualquer estética, até mesmo da mais bela obra pictórica.

$\mathrm{O}$ artista tentou finalizar um período de aparências e de cópias sobre "o belo". Em um momento histórico conturbado por guerras e revoluções, alguns artistas encontraram a saída por meio de uma apresentação do invisível do visível no mundo. Por meio de obras monocromáticas com formas básicas, Maliévitch tentou criar um alfabeto formado por novos signos.

Poderíamos concluir que uma das intenções de sua poética visual seria intuir o observador a encontrar novos caminhos e significados dentro de si. Mesmo que a obra dependesse de um corpo físico, no caso a tela, a presença do "imaterial" foi uma característica constante em seus trabalhos.

Na obra de Rothko, também notamos a necessidade de apresentar a matéria de modo harmônico. O artista, que também viveu num período de guerra, encontrou na abstração e no sensível sua "porta de saída". A poética de Rothko, com seus campos de cor, não remete a nenhuma forma ou objeto aparente. Assim como em Maliévitch, poderíamos dizer que é uma pintura que anseia por um observador ora principal, ora coadjuvante na obra, na qual há uma interação física e intelectual entre os corpos.

A presente dissertação procurou abordar questões relacionadas a uma compreensão do que é sensível na arte moderna de Maliévitch, estendendo esse olhar a alguns aspectos da obra de Rothko, que, ao ver da pesquisadora, encontram interseções bastante significativas. Pesquisando sobre temas e pessoas influentes envolvidas no momento histórico dos artistas, nos aproximamos 
da noção da importância daquilo que não se vê, mas, ao sentir, percebe-se na visualidade da pintura.

Se fosse possível deixarmos de lado, mesmo por um minuto, toda a potência das poéticas de Maliévitch e Rothko, poderíamos considerar que o "invisível-visível” encontrado nas obras desses artistas se encontraria muito além do pictórico para oferecer uma sensibilidade um mundo melhor, mais harmônico, mais transcendental. Para a atualidade do mundo, essa arte está a serviço da evolução humana com sua "estética relacional", como a Capela Rothko propõe e antecipa a arte contemporânea do século XXI.

Esses estudos ofereceram à pesquisadora uma ampliação do Quadrado branco de Maliévitch, origem de toda essa pesquisa sobre sua poética visual, sensibilidade e intencionalidade, que se estenderam a um artista russo também, mas mais contemporâneo, Mark Rothko.

Talvez esses olhares lançados aqui e ali possam servir como um simples exemplo para a educação e a arte de tempos incertos. 


\section{REFERÊNCIAS}

A PLACE CALLED SPACE. Kazimir Malevich. Disponível em: <http://a-place-calledspace.blogspot.com/2014/11/kazimir-malevich.html>.

ADORNO, T. et al. The Romantics were Prompted. New York, 1947.

AGUILAR, Nelson, et al. 500 Anos de Arte Russa. Brasil Connects, 2002.

ARANHA, Carmen C. S. G.; BRITO, Amaury C.; ROSATO, Alex. Cultura de visualidades: aproximações da linguagem artístico-visual. São Paulo, 2011.

ARGAN, Giulio Carlo. Arte Moderna. São Paulo: Companhia das Letras, 1992.

BALL-TESHUVA, Jacob. Rohtko. Taschen, 2003.

BERMEJO, J. M. F. Grandes Pintores do Século XX - Malevich. Madrid, 1995.

BUSHKOVITCH, Paul. História Concisa da Rússia. São Paulo: Edipro, 2015.

CANÇÃO NOVA. São Sérgio, considerado o grande educador do povo russo. Disponível em: <https://santo.cancaonova.com/santo/sao-sergio-considerado-o-grande-educador-do-povorusso/>.

CENTRO CULTURAL BANCO DO BRASIL. Gráfica Utópica - Arte Gráfica Russa 1904-1942. São Paulo, 2002.

CHIPP, H. B. Teorias da Arte Moderna. São Paulo: Martins Fontes, 1999.

DANTO, Arthur. Após o fim da Arte. São Paulo: Odysseus Editora, 2006.

DE MICHELLI, Mario. As Vanguardas Artísticas. São Paulo: Martins Fontes, 2002.

DEMPSEY, Amy. Estilos, Escolas \& Movimentos. São Paulo: Cosac \& Naify, 2008.

DRUTT, Matthew. Kazimir Malevich: Suprematism. Guggenheim Museum, 2003.

FLORIÊNSKI, Pável. A Perspectiva Inversa. São Paulo: Editora 34 Ltda, 2012.

GRAY, Camilla. O Grande Experimento Arte Russa, 1863 - 1917. São Paulo: World White All Editora, 2004.

GREEBERG, Clement. Arte e Cultura. Ensaios críticos. São Paulo: Cosac \& Naify, 2014.

GOMBRICH, E. H. A História da Arte. Rio de Janeiro: LTC, 1999.

HARRIS, Nathaniel. A Arte de Cézanne. Rio de Janeiro: Ao Livro Técnico S/A, 1982.

HARRISON, C. et al. Modernismo em Disputa. A arte desde os anos quarenta. São Paulo: Cosac \& Naify, 1998. 
HARRISON, Charles; FRASCINA, Francis; PERRY, Gill. Primitivismo, Cubismo, Abstração. São Paulo: Cosac \& Naify, 1998.

HUDSON, Suzanne. Robert Ryman. Massachusetts Institute of Technology, 2009.

JANSON, H. W. História da Arte. 3. ed. Fundação Calouste Gulbenkian, 1998.

LACHMAN, Gary. Madame Blavatsky. A Mãe da Espiritualidade Moderna. São Paulo: Editora Pensamento-Cultrix, 2014.

MALEVICH, K. From cubism and futurism to suprematism. Disponível em: <http://www.mariabuszek.com/mariabuszek/kcai/ConstrBau/Readings/MlevchSupr.pdf $>$.

MALIÉVITCH, Kazimir. Dos Novos Sistemas na Arte. São Paulo: Editora Hedra, 2007.

MARZONA, Daniel. Minimal art. Taschen, 2004.

MELTON PRIOR INSTITUTE. Disponível em: <www.meltonpriorinstitut.org>

MERLEAU-PONTY, Maurice. O olho e o espírito. São Paulo: Cosac\&Naify, 2004.

ROSE, Barbara. Monochromes. From Malevich to the Present. University of California Press, 2004.

ROTHKO, Mark. Mark Rothko. Escritos sobre arte (1934-1969). Spain: Espasa Libros, 2015.

ROSE, Barbara. Monochromes. From Malevich to the present. Madrid, 2006.

RUSSIAN CULTURE. Russian Lubok. Disponível em: <allrus.me/russian-lubok>.

SARDENBERG, Ricardo. Arte Contemporânea no século XXI. Rio de Janeiro: Capivara Editora, 2011.

SCHARF, Aron. Suprematismo. In: STANGOS, Nikos (Org.). Conceitos da Arte Moderna. Tradução de Álvaro Cabral. Rio de Janeiro: Jorge Zahar, 2000. p. 100-102.

SOUTER, Gerry. Malevich. Journey to Infinity. New York: Parkstone Press International.

SIMMEN Jeannot; KOHLHOFF Kolja. Miniguia de Arte: Malevitch. Portugal: Könemann, 2001.

WIKIART. Contrast of form. Disponível em: <https://www.wikiart.org/en/fernandleger/contrast-of-form-1913>.

WILDENSTEIN, Daniel. Monet or the Triumph of Impressionism. Taschen, Slovenia, 2003. 


\section{APÊNDICE A}

Com o intuito de ilustrar um pouco mais sobre a repercussão das influências póssuprematistas, apresentaremos obras de alguns artistas que carregaram alguma influência do artista russo sobre suas poéticas, seja sobre o modo de pensar, seja sobre o resultado pictórico. Nesse momento, não teremos o propósito de apresentar algum tipo de análise sobre alguma obra. A ideia é somente demonstrar como o Suprematismo possa ter repercutido, direta ou indiretamente, nos trabalhos artísticos, após Maliévitch. Esse breve passeio se iniciará com obras de artistas do início do século XX e se estenderá até os dias atuais.

Na década de 1920, Maliévitch, em parceria com El Lissitsky (arquiteto), desenvolveu o suprematismo espacial, os arquitéctonos (SIMMEN; KOHLHOFF, 2001).

Os architéctonos são blocos volumétricos, Architéctono Alpha (Figura 1) e Architéctono Gota (Figura 2), com inesgotáveis possibilidades de combinação, que influenciaram a arquitetura e o design do século XX.

[...] Quando estive com alguns dirigentes culturais russos, falei da importância de Maliévitch para o Brasil, a que me responderam para o mundo inteiro [...] "Mas o resto do mundo não fez algo como Brasília que parece ter surgido dos Arquitéctonos" (NELSON, in Aguilar, p. 36).

\section{Figura 1 - Architéctono Alpha}

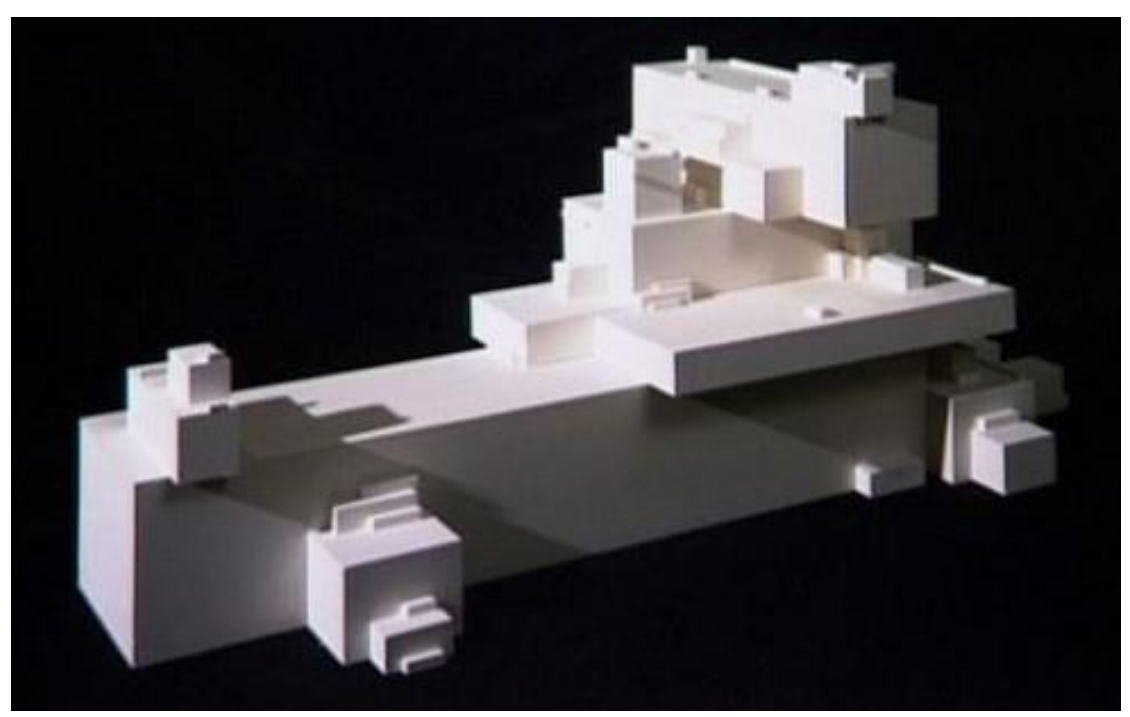

Fonte: Aguilar (2002). Gesso, 31,5x80,5x34cm. 
Figura 2 - Architéctono Gota

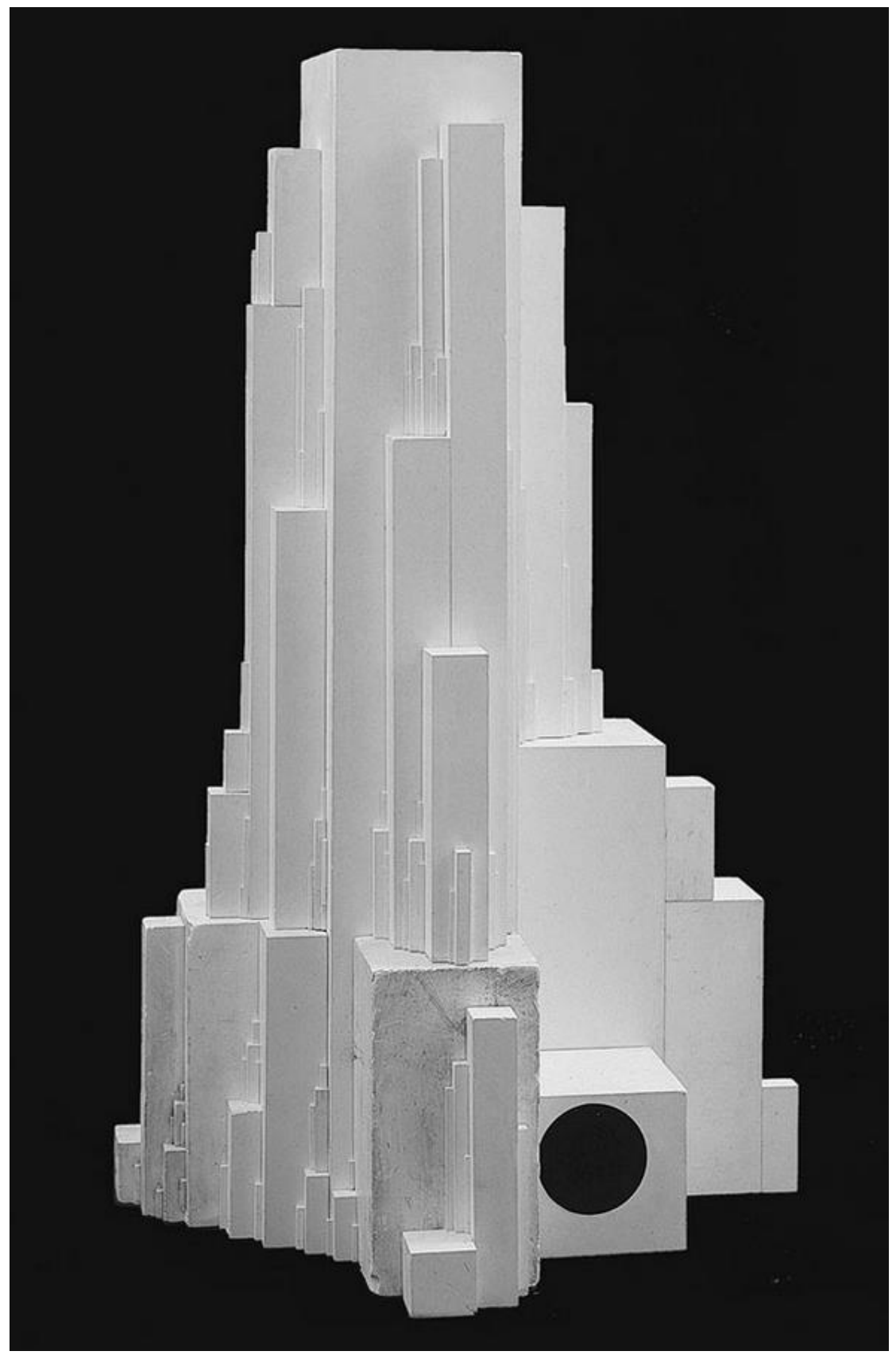

Fonte: Aguilar (2002). Gesso, 85,3x56x52,5cm.

Vários artistas contemporâneos a Maliévitch se apropriaram de formas geométricas na pintura. Josef Albers (1888-1976) foi artista e educador, aluno e professor da Bauhaus (ARGAN, 1999). O artista trabalhou com a forma do Quadrado em suas pinturas, utilizando uma combinação cromática diferenciada. Os quadrados são inseridos uns nos outros, quase de modo matemático. Através das cores, Albers conseguiu proporcionar um efeito ilusório nas sobreposições dos quadrados, que ora parecem estar à frente, ora parecem estar atrás, conforme observamos na pintura Study to told (Figura 3). 
Sobre isto:

A concepção do espaço como integridade plástica do plano (profundidaderelevo) de Albers teve uma importância determinante, seja para a concepção do espaço em expansão, aquém do plano do quadro, de Rothko, seja para a chamada cor rente do hard edge (Barnett Newmann) (ARGAN, 1999, p. 615).

\section{Figura 3 - Study to told -1960}

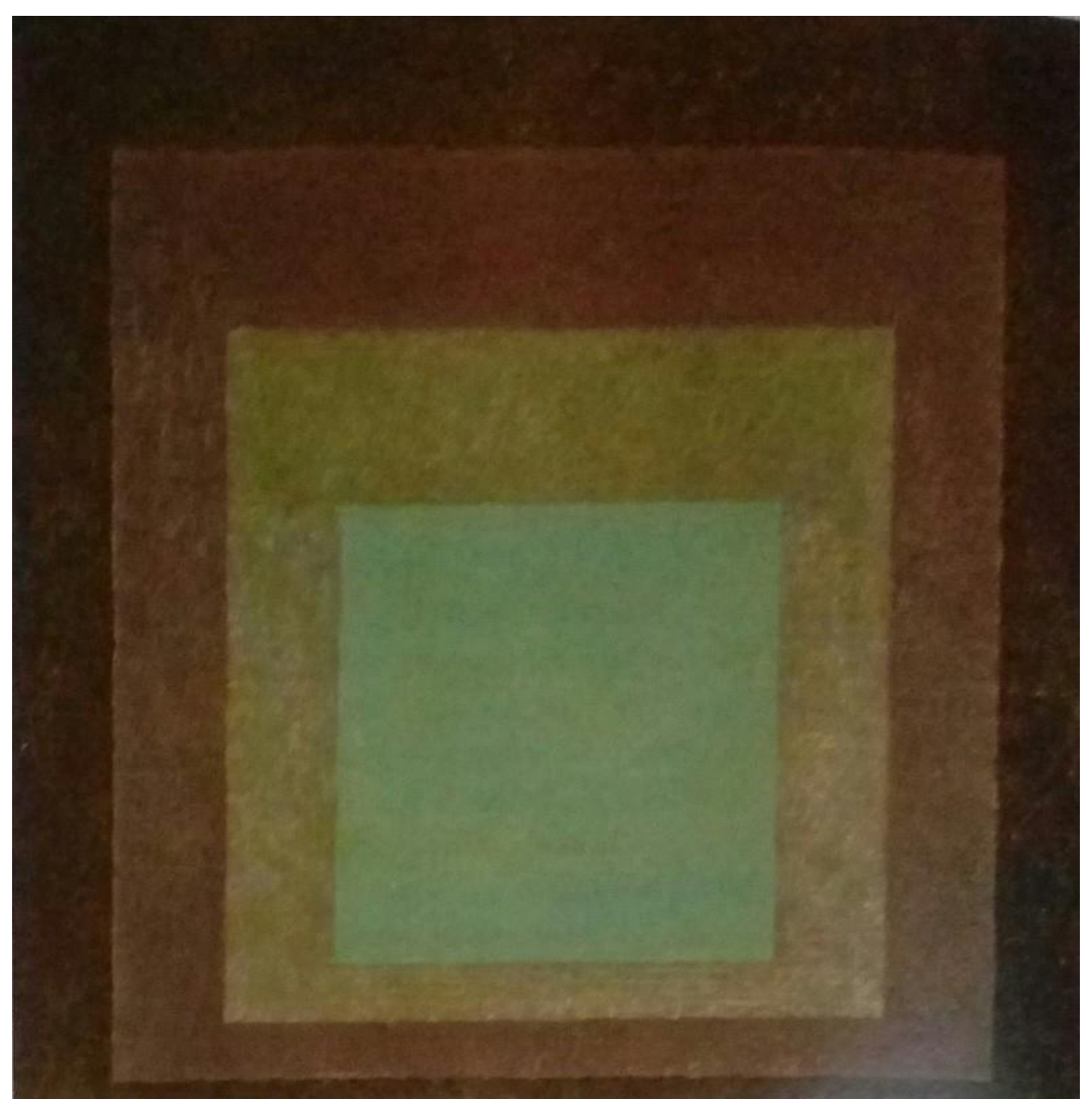

Fonte: Argan (1999). 0,61x0,61m. Óleo sobre masonite.

O minimalismo nas artes plásticas surgiu na década de 1960, e os artistas atuantes defendiam uma arte que atendesse primeiramente a uma ideia concebida pela mente, portanto o saber-fazer artístico que poderíamos chamar também de talento não importava. A obra final não necessitaria carregar algum tipo de expressão do artista. Havia o predomínio de formas geométricas, geralmente repetidas em série. Na maioria dos casos, essas obras eram construídas em ambiente industrial.

Quando, em 1913, Malevich colocou um quadrado negro sobre um fundo branco, ele afirmou que "a arte não se preocupa mais em servir ao Estado ou à religião; ela não deseja mais ilustrar a história dos costumes" [...] Com isso ele lançou os alicerces para uma arte secular, desligada de propósitos utilitários e afastada da função ideológica da representação (GABLIK in STANGOS, 1991 p. 174). 
Podemos notar uma espécie de paradoxo ao tentarmos encontrar alguma influência suprematista no Minimalismo, pois, enquanto no Suprematismo, o que importa é o sentimento, no Minimalismo o que importa é a ideia. No entanto, a poética visual adotada pelos artistas minimalistas está inteiramente relacionada com a simplicidade de cores e formas geométricas do Suprematismo, como podemos observar na obra de Robert Mangold Three squares within a triangle (Figura 4) e Sol Lewitt com a obra HRZL (Figura 5).

Figura 4 - Three squares within a triangle -1976

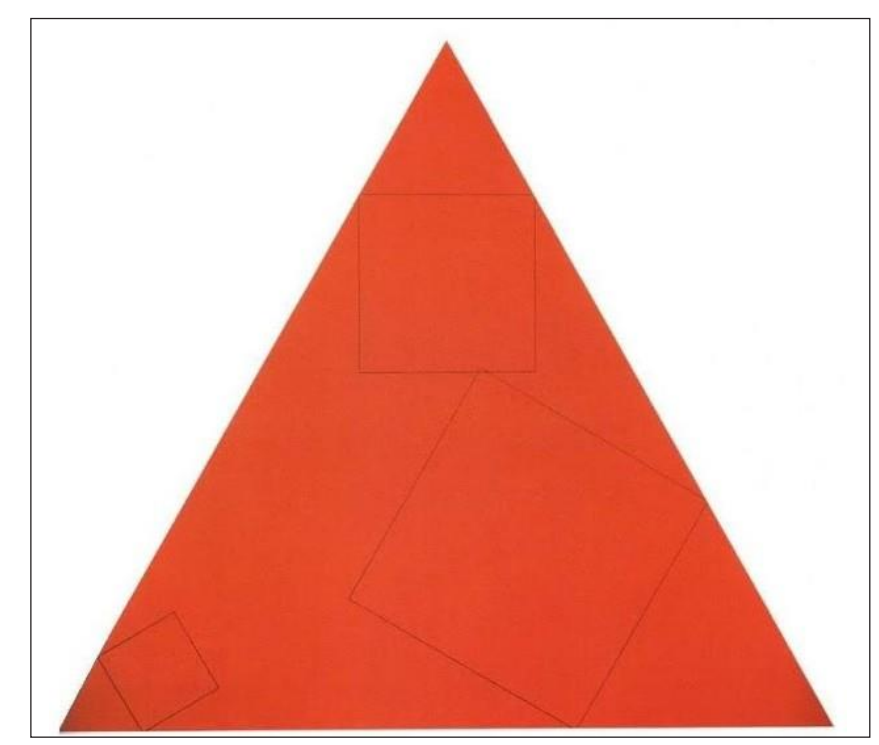

Fonte: Marzona (2004). 145x183cm. Acrílica e lápis sobre linho. 
Figura 5 - HRZL 1 - 1990

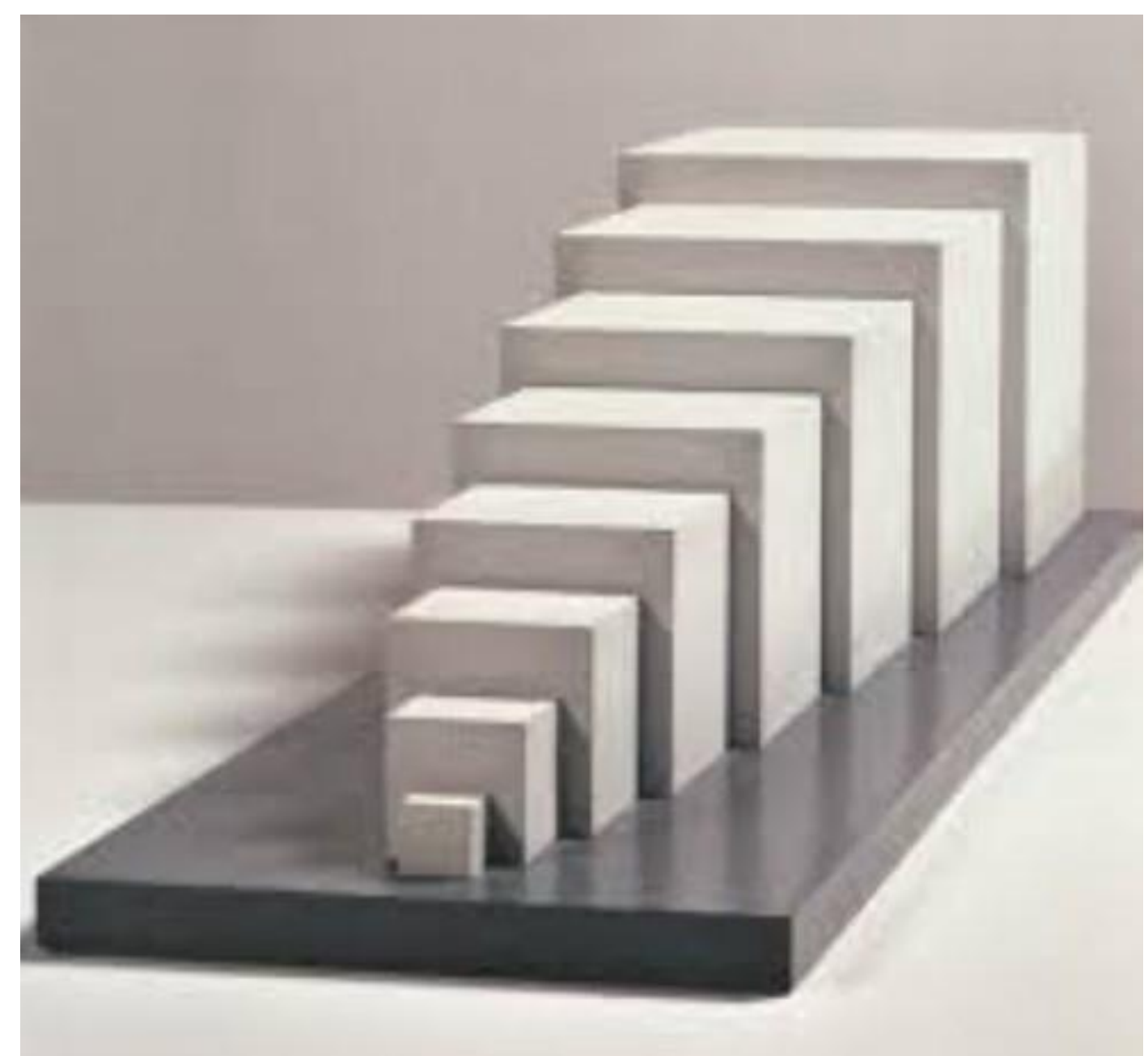

Fonte: Marzona (2004). 160x160x720cm. Blocos de cimento.

Outra característica pictórica que incorporou no início do século XX, utilizada com um forte propósito, foi a monocromia. A opção de Maliévitch em trabalhar com uma só cor foi um ato inovador para sua época. As obras monocromáticas tendem a levar o espectador a uma experiência visual intimista, um tipo de linguagem visual que pode ser entendida, sentida ou interpretada em qualquer lugar do mundo.

Sobre este aspecto:

[...] the monochrome is a solitary experience, both for the artist and for the viewer. Today, an era dominated by the mass media spectacle, the monochrome is a refuge of serious philosophical discourse. Monochrome art has always been elitist [...] It goes nowhere and everywhere, it is specific and universal, tangible and immaterial (ROSE, 2006, p. 80) ${ }^{19}$.

19 “[...] o monocromático é uma experiência solitária, tanto para o artista quanto para o espectador. Hoje, uma era dominada pelo espetáculo da mídia de massa, o monocromático é um refúgio do discurso filosófico sério. A arte monocromática sempre foi elitista [...] Ela vai a lugar nenhum e em toda parte, é específica e universal, tangível e imaterial". 
Poderíamos conferir inúmeros artistas que adotaram a monocromia como parte de sua poética, tanto na pintura, como em esculturas e instalações.

Yves Klein (1928-1962) foi um artista francês com uma poética visual diversificada, adotou a monocromia em seus trabalhos, em especial o azul intenso, que o patenteou como: International Klein Blue. Podemos conferir essas propostas nas obras Hiroshima (Figura 6) e ANT 54 (Figura 7).

Figura 6 - ANT, 79 Hiroshima, vers 1961

Fonte: Weitemeier.

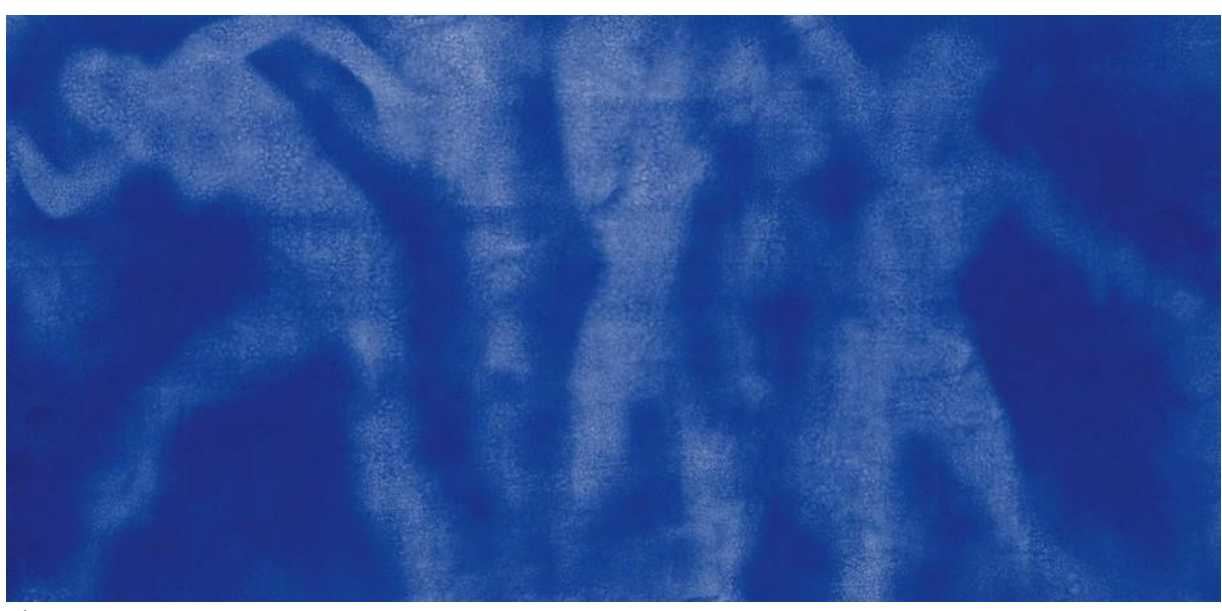


Figura 7 - ANT 54 - 1960

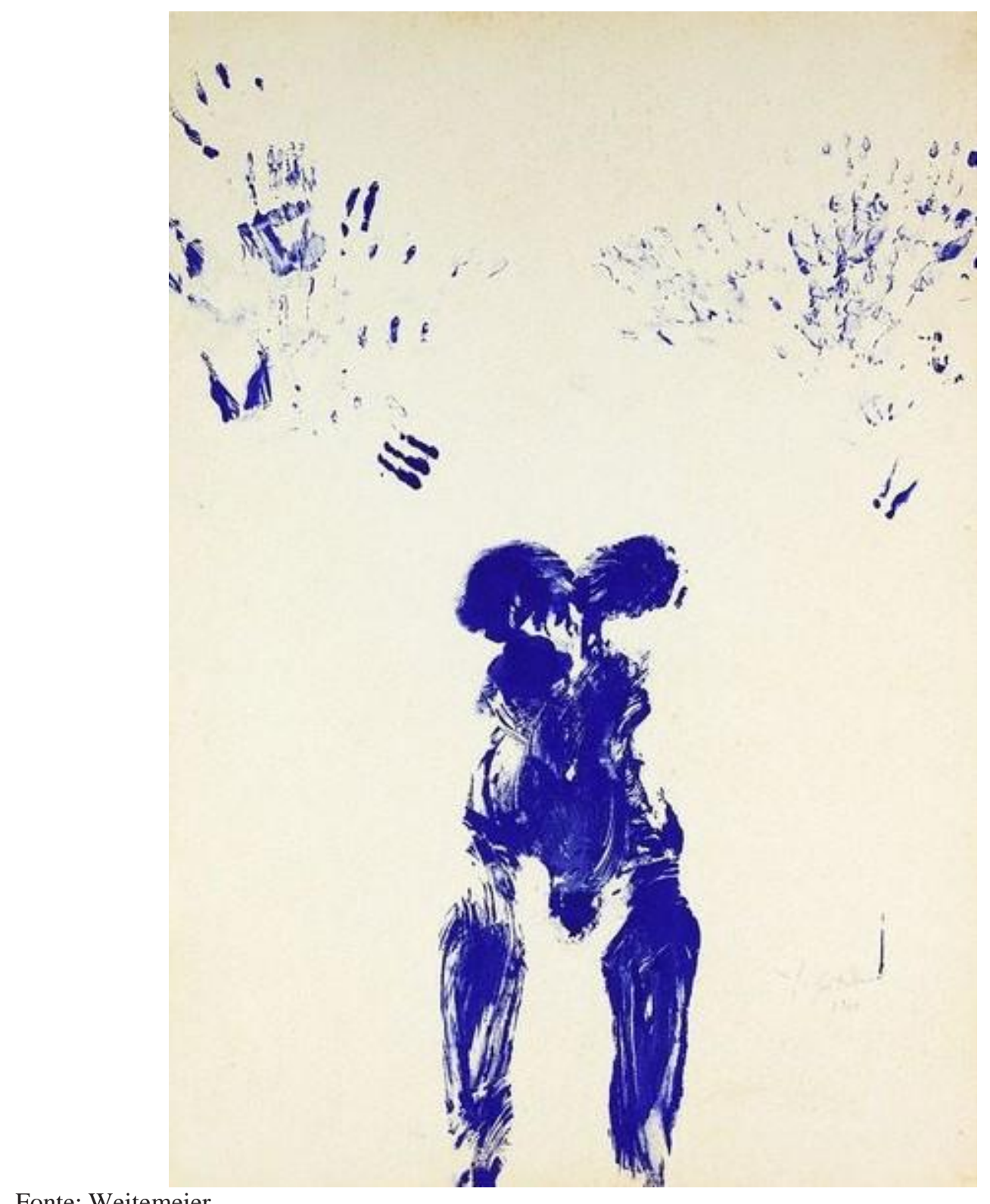

Fonte: Weitemeier.

Cildo Meireles, 1948 - hoje, é um artista conceitual brasileiro, com carreira internacional, adotou a monocromia para a instalação Desvios para o Vermelho: Impregnação (Figura 8). 
Figura 8 - Desvios para o Vermelho: Impregnação - 1967 - 1984

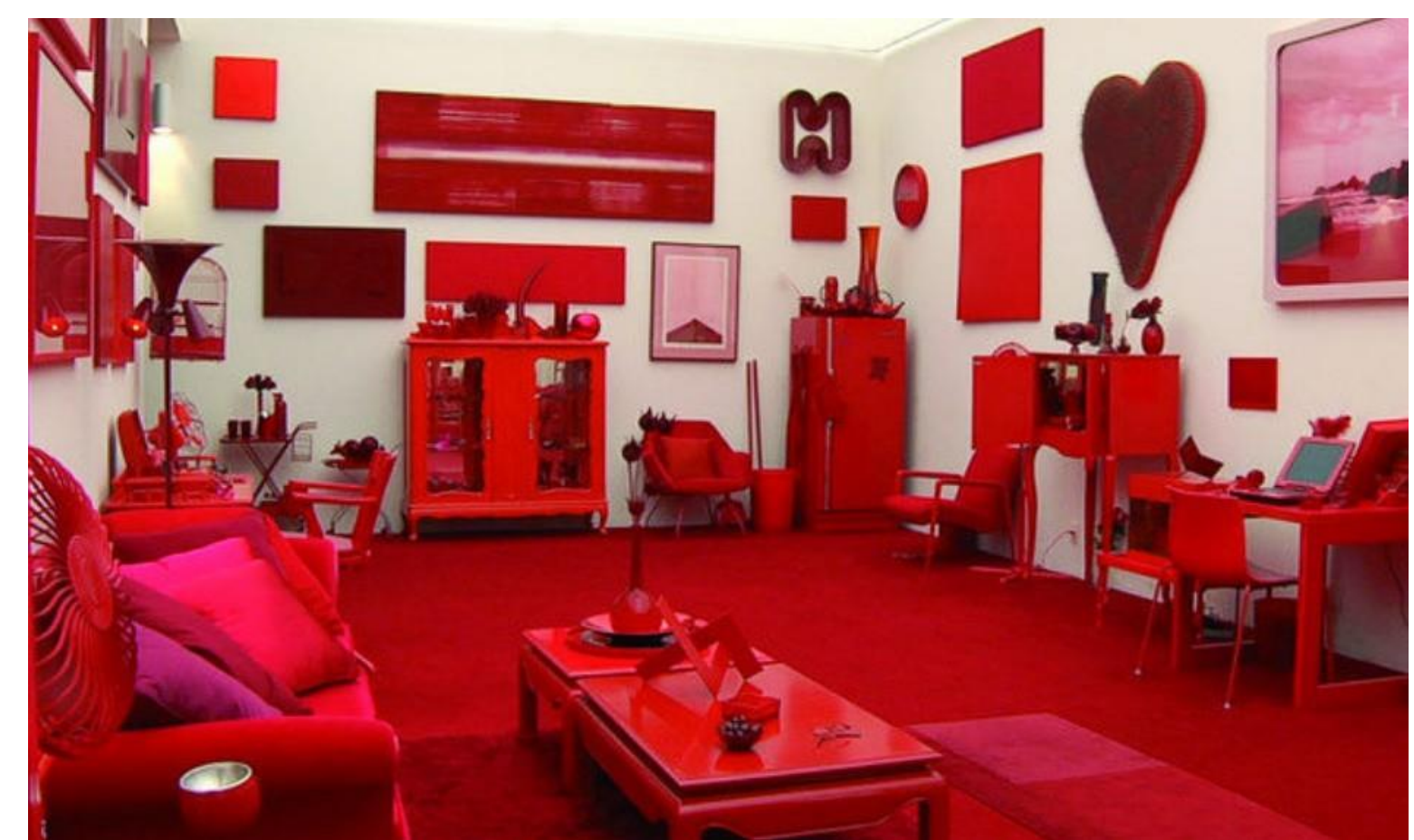

Fonte: Sardenberg. Técnica mista.

Para finalizarmos uma lista de artistas que poderiam tender ao infinito em relação à monocromia, falaremos um pouco sobre a obra de Robert Ryman 1930 - hoje, um artista americano que adotou a monocromia como característica principal de sua proposta visual. Para isso, escolheu o uso constante do branco. Segue na pintura Mayco (Figura 9).

Essa poética adotada por Ryman trouxe à tona uma questão que há tempos tem sido abordada e discutida, que é sobre a morte da pintura. Diferente de Maliévitch, que a monocromia e o branco foram resultados do desenvolvimento de seu percurso poético, em Ryman o uso do branco sempre foi uma constante (DANTO, 2006). Quando Maliévitch propôs o Quadrado Preto para o início de um novo realismo pictórico, o artista de algum modo antecipou, através de uma pintura monocromática, o que mais tarde seria e ainda é questionado. A possível morte da pintura é um tema atual, mas não concluído. Poderíamos acreditar numa temática inesgotável. 
Figura 9 - Mayco - 1966

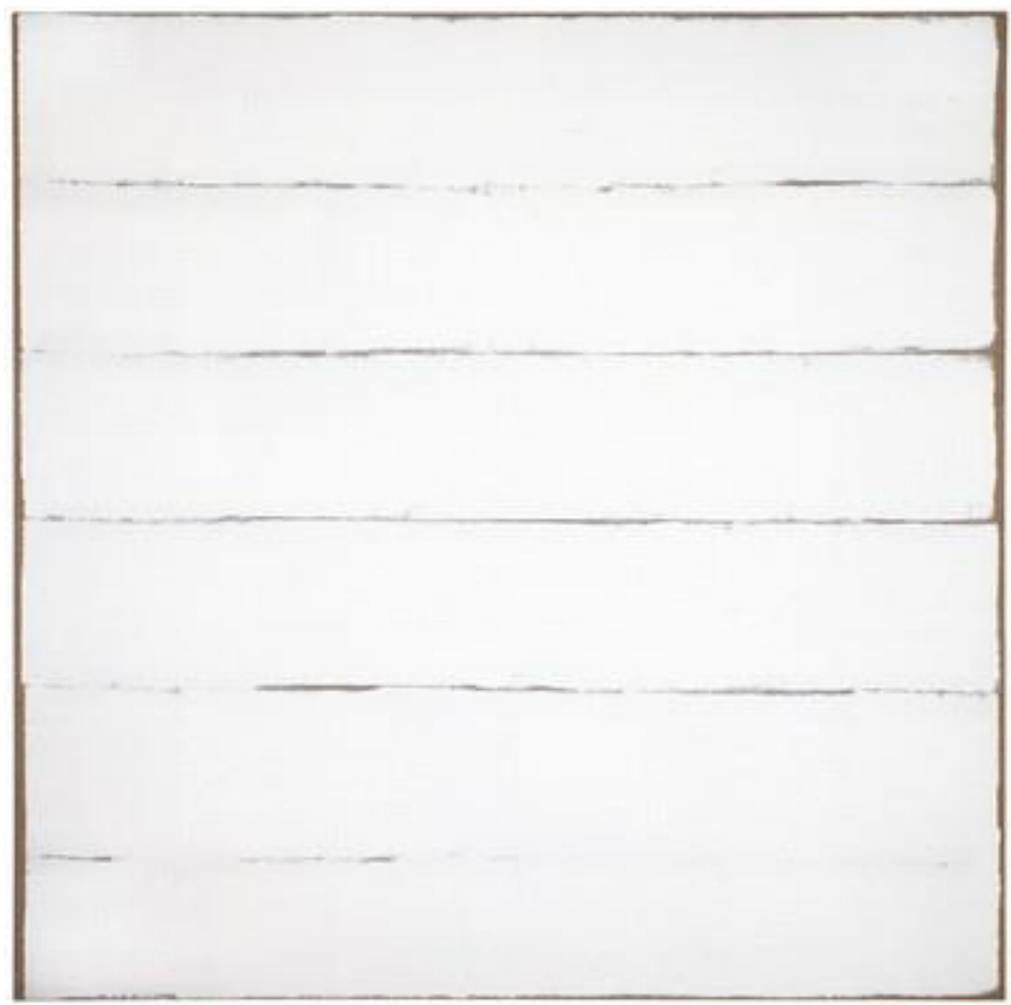

Fonte: Hudson. Winsor white oil on stretched sized linen canvas. 